Supporting Information for:

\title{
Redox-Inactive Metal Cations Modulate the Reduction Potential of the Uranyl Ion in Macrocyclic Complexes
}

\author{
Amit Kumar, ${ }^{\#}$ Davide Lionetti, ,'† Victor W. Day ${ }^{\#}$ and James D. Blakemore ${ }^{\#, *}$ \\ \# Department of Chemistry, University of Kansas, 1567 Irving Hill Road, \\ Lawrence, Kansas 66045, United States \\ $\dagger$ Department of Chemistry, Franklin \& Marshall College, P.O. Box 3003, \\ Lancaster, Pennsylvania 17604, United States \\ * To whom correspondence should be addressed: blakemore@ku.edu (J.D.B.)
}

\section{Contents}

NMR Spectra

Figure S1. ${ }^{1} \mathrm{H}$ NMR spectrum of 3,3'-(3,6-Dioxaoctane-1,8-diyldioxy)bis(2hydroxybenzaldehyde).

Figure S2. ${ }^{1} \mathrm{H}$ NMR spectrum of $\mathbf{L}^{\text {salben }} \mathbf{H}_{2} \mathbf{B a}$

Figure S3. ${ }^{13} \mathrm{C}\left\{{ }^{1} \mathrm{H}\right\}$ NMR spectrum of $\mathbf{L}^{\text {salben}} \mathbf{H}_{2} \mathbf{B a} \quad$ S5

Figure S4. ${ }^{19} \mathrm{~F}$ NMR spectrum of $\mathbf{L}^{\text {salben }} \mathbf{H}_{2} \mathbf{B a} \quad$ S5

Figure S5. ${ }^{1} \mathrm{H}$ NMR spectrum of $\mathbf{L}^{\text {salben }} \mathbf{U O}_{2} \quad$ S6

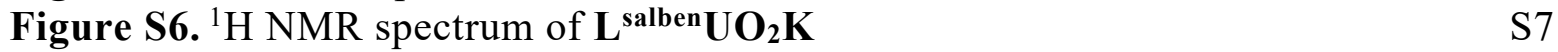

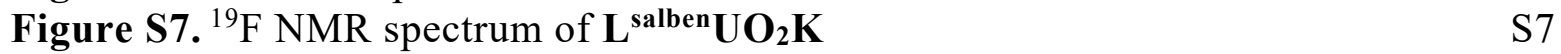

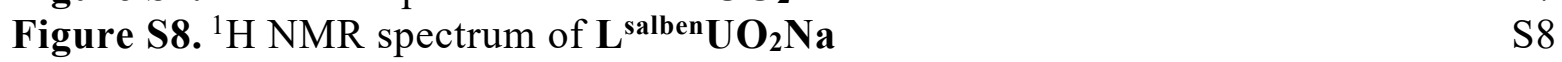

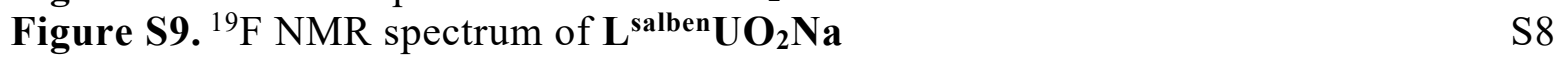

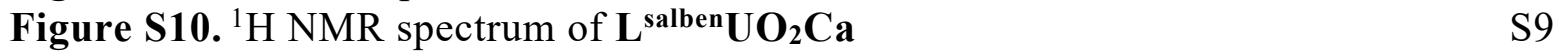

Figure S11. ${ }^{19} \mathrm{~F}$ NMR spectrum of $\mathbf{L}^{\text {salben }} \mathbf{U O}_{2} \mathbf{C a} \quad$ S9

Figure S12. ${ }^{1} \mathrm{H}$ NMR spectrum of $\mathbf{L}^{\text {salben }} \mathbf{U O}_{2} \mathbf{N d} \quad \mathrm{S} 10$

Figure S13. ${ }^{19} \mathrm{~F}$ NMR spectrum of $\mathbf{L}^{\text {salben }} \mathbf{U O}_{2} \mathbf{N d} \quad \mathrm{S} 10$

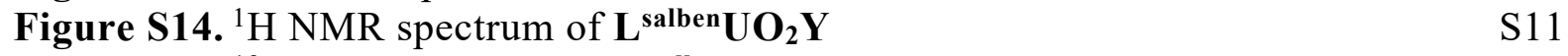

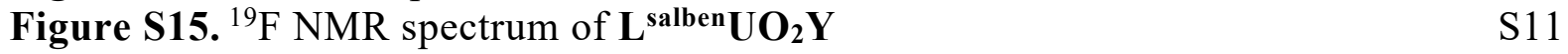

$\begin{array}{ll}\text { Features of the uranyl containing complexes } & \mathrm{S} 12\end{array}$

Electronic Absorption Spectra $\quad$ S13

Figure S16. Electronic absorption spectrum of $\mathbf{L}^{\text {salben }} \mathbf{U O}_{2} \quad \mathrm{~S} 13$

Figure S17. Electronic absorption spectrum of $\mathbf{L}^{\text {salben }} \mathbf{U O}_{2} \mathbf{K} \quad \mathrm{S} 13$

Figure S18. Peak Deconvolution of Electronic absorption spectrum of $\mathbf{L}^{\text {salben }} \mathbf{U O}_{2} \mathbf{K} \quad \mathrm{S} 14$

Figure S19. Electronic absorption spectrum of $\mathbf{L}^{\text {salben }} \mathbf{U O}_{2} \mathbf{N a} \quad \mathrm{S} 15$

Figure S20. Electronic absorption spectrum of $\mathbf{L}^{\text {salben }} \mathbf{U O}_{2} \mathbf{C a} \quad \mathrm{S} 15$

Figure S21. Electronic absorption spectrum of $\mathbf{L}^{\text {salben }} \mathbf{U O}_{2} \mathbf{N d} \quad \mathrm{S} 16$

Figure S22. Electronic absorption spectrum of $\mathbf{L}^{\text {salben }} \mathbf{U O}_{2} \mathbf{Y} \quad \mathrm{S} 16$

Figure S23. Stacked Electronic absorption spectrum showing $\pi-\pi *$ transitions $\quad$ S17 
Figure S24. CV Data for $\mathbf{L}^{\text {salben }} \mathbf{U O}_{2}$

Figure S25. Scan rate dependence data for $\mathbf{L}^{\text {salben }} \mathbf{U O}_{2} \quad$ S18

Figure S26. Chemical reversibility analysis of $\mathbf{L}^{\text {salben }} \mathbf{U O}_{2} \quad \mathrm{~S} 19$

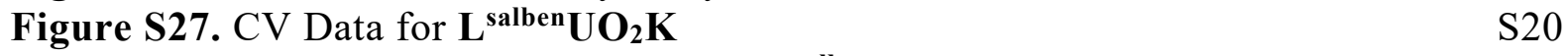

Figure S28. Scan rate dependence data for $\mathbf{L}^{\text {salben }} \mathbf{U O}_{2} \mathbf{K} \quad$ S20

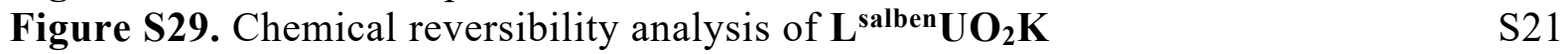

Figure S30. CV Data for $\mathbf{L}^{\text {salben }} \mathbf{U O}_{2} \mathbf{N a}$ (Early Scan) $\quad$ S22

Figure S31. Scan rate dependence data for $\mathbf{L}^{\text {salben }} \mathbf{U O}_{2} \mathbf{N a} \quad$ S22

Figure S32. CV Data for $\mathbf{L}^{\text {salben }} \mathbf{U O}_{2} \mathbf{N a}$ (Late Scan) $\quad$ S23

Figure S33. CV Data for $\mathbf{L}^{\text {salben }} \mathbf{U O}_{2} \mathbf{N a}$ using two different electrodes $\quad$ S23

Figure S34. CV Data for $\mathbf{L}^{\text {salben }} \mathbf{U O}_{2} \mathbf{C a}$ (Smaller Potential Window) $\quad$ S24

Figure S35. CV Data for $\mathbf{L}^{\text {salben }} \mathbf{U O}_{2} \mathbf{C a}$ (Larger Potential Window) $\quad$ S24

Figure S36. Scan rate dependence data for $\mathbf{L}^{\text {salben }} \mathbf{U O}_{2} \mathbf{C a} \quad \mathrm{S} 25$

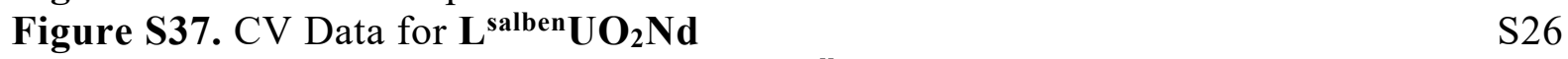

Figure S38. Scan rate dependence data for $\mathbf{L}^{\text {salben }} \mathbf{U O}_{2} \mathbf{N d} \quad$ S26

$\begin{array}{ll}\text { Figure S39. CV Data for } \mathbf{L}^{\text {salben }} \mathbf{U O}_{2} \mathbf{Y} & \text { S27 }\end{array}$

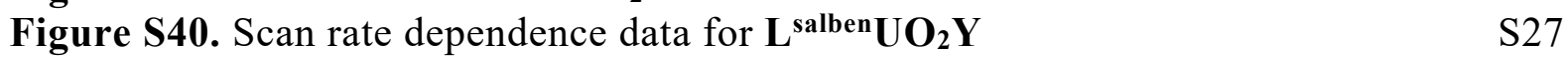

Figure S41. CV data of $\mathbf{L}^{\text {salben }} \mathbf{U O}_{2} \mathbf{K}$ after addition of 3 equiv. of $\mathrm{Y}(\mathrm{OTf})_{3} \quad$ S28

Figure S42. $\mathrm{CV}$ data of $\mathbf{L}^{\text {salben }} \mathbf{U O}_{2} \mathbf{C a}$ after addition of 3 equiv. of $\mathrm{Y}(\mathrm{OTf})_{3} \quad$ S28

Figure S43. CV data of $\mathbf{L}^{\text {salben }} \mathbf{U O}_{2} \mathbf{C a}$ after addition of 3 equiv. of K(OTf) $\quad$ S29

Spectroelectrochemistry $\quad$ S30

Figure S44. Spectroelectrochemical data for the electrolysis of $\mathbf{L}^{\text {salben}} \mathbf{U}^{\mathbf{V I}} \mathbf{O}_{2} \quad \mathrm{~S} 30$

Figure S45. Spectroelectrochemical data for the electrolysis of $\mathbf{L}^{\text {salben }} \mathbf{U}^{\mathbf{V I}} \mathbf{O}_{2} \mathbf{K} \quad$ S31

Figure S46. Stacked Spectroelectrochemical data for $\mathbf{L}^{\text {salben }} \mathbf{U}^{\mathbf{V I}} \mathbf{O}_{2} \mathbf{K}$ (full region) $\quad \mathrm{S} 32$

Figure S47. Stacked Spectroelectrochemical data for $\mathbf{L}^{\text {salben}} \mathbf{U}^{\mathbf{V I}} \mathbf{O}_{2} \mathbf{K}$ (small region) S32

X-Ray Crystallography

$\begin{array}{ll}\text { Special Refinement Details for } \mathrm{L}^{\text {salben }} \mathrm{H}_{2} \mathrm{Ba} & \mathrm{S} 35\end{array}$

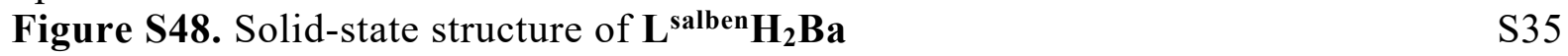

Figure S49. Solid-state structure of $\mathbf{L}^{\text {salben }} \mathbf{H}_{2} \mathbf{B a}$ with H-atoms $\quad$ S35

Figure S50. Ball and stick representation of $\mathbf{L}^{\text {salben}} \mathbf{H}_{2} \mathbf{B a} \quad$ S36

Special Refinement Details for $\mathbf{L}^{\text {salben }} \mathbf{U O}_{2} \quad$ S37

Figure S51. Solid-state structure of $\mathbf{L}^{\text {salben }} \mathbf{U O}_{2} \quad$ S37

Figure S52. Ball and stick representations of $\mathbf{L}^{\text {salben }} \mathbf{U O}_{2} \quad$ S37

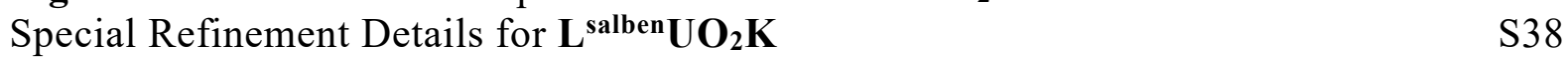

Figure S53. Solid-state structure of $\mathbf{L}^{\text {salben }} \mathbf{U O}_{2} \mathbf{K} \quad$ S38

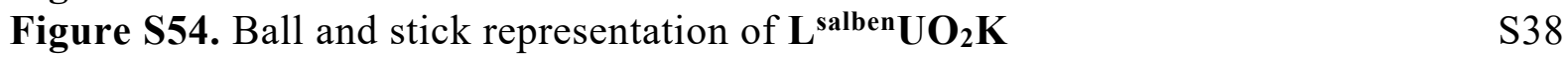

$\begin{array}{ll}\text { Special Refinement Details for } \mathbf{L}^{\text {salben }} \mathbf{U O}_{2} \mathbf{N a} & \text { S39 }\end{array}$

Figure S55. Solid-state structure of $\mathbf{L}^{\text {salben }} \mathbf{U O}_{2} \mathbf{N a} \quad$ S39

Figure S56. Ball and stick representation of $\mathbf{L}^{\text {salben }} \mathbf{U O}_{2} \mathbf{N a} \quad$ S39

Special Refinement Details for $\mathbf{L}^{\text {salben }} \mathbf{U O}_{2} \mathbf{C a} \quad \mathrm{S} 40$

Figure S57. Solid-state structure of $\mathbf{L}^{\text {salben }} \mathbf{U O}_{2} \mathbf{C a} \quad S 41$

Figure S58. Solid-state structure of $\mathbf{L}^{\text {salben }} \mathbf{U O}_{2} \mathbf{C a}$ with few H-atoms $\quad$ S42

Figure S59. Solid-state structure of $\mathbf{L}^{\text {salben }} \mathbf{U O}_{2} \mathbf{C a}$ with few H-atoms $\quad$ S43 
Figure S60. Ball and stick representation of $\mathbf{L}^{\text {salben}} \mathbf{U O}_{2} \mathbf{C a} \quad S 43$

$\begin{array}{ll}\text { Special Refinement Details for } \mathbf{L}^{\text {salben }} \mathbf{U O}_{2} \mathbf{Y} & \text { S44 }\end{array}$

Figure S61. Solid-state structure of $\mathbf{L}^{\text {salben }} \mathbf{U O}_{2} \mathbf{Y}$ without outer-sphere triflate anion S44

Figure S62. Solid-state structure of $\mathbf{L}^{\text {salben }} \mathbf{U O}_{2} \mathbf{Y}$ with outer-sphere triflate anion $\quad$ S44

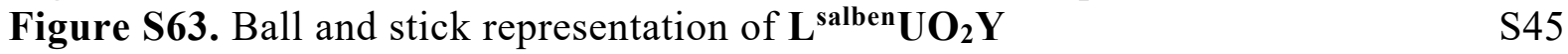

Table S1. Crystal and Refinement Data for $\mathbf{L}^{\text {salben}} \mathbf{H}_{2} \mathbf{B a}$ and $\mathbf{L}^{\text {salben }} \mathbf{U O}_{2} \quad$ S46

Table S2. Crystal and Refinement Data for $\mathbf{L}^{\text {salben }} \mathbf{U} \mathbf{O}_{2} \mathbf{K}$ and $\mathbf{L}^{\text {salben }} \mathbf{U O}_{2} \mathbf{N a} \quad$ S47

Table S3. Crystal and Refinement Data for $\mathbf{L}^{\text {salben}} \mathbf{U} \mathbf{O}_{2} \mathbf{C a}$ and $\mathbf{L}^{\text {salben }} \mathbf{U} \mathbf{O}_{2} \mathbf{Y} \quad$ S48

$\begin{array}{ll}\text { References } & \text { S49 }\end{array}$ 


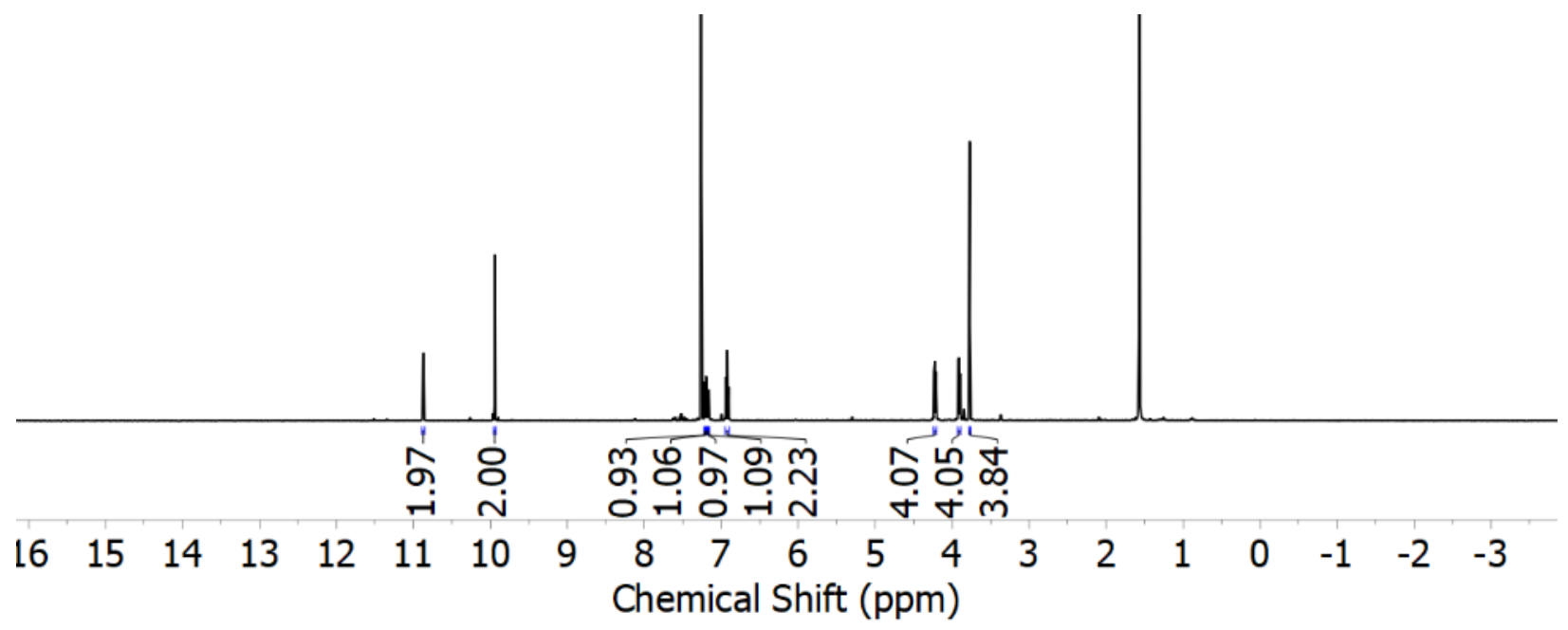

Figure S1. ${ }^{1} \mathrm{H}$ NMR spectrum $\left(400 \mathrm{MHz}, \mathrm{CD}_{3} \mathrm{CN}\right)$ of 3,3'-(3,6-Dioxaoctane-1,8diyldioxy)bis(2-hydroxybenzaldehyde).

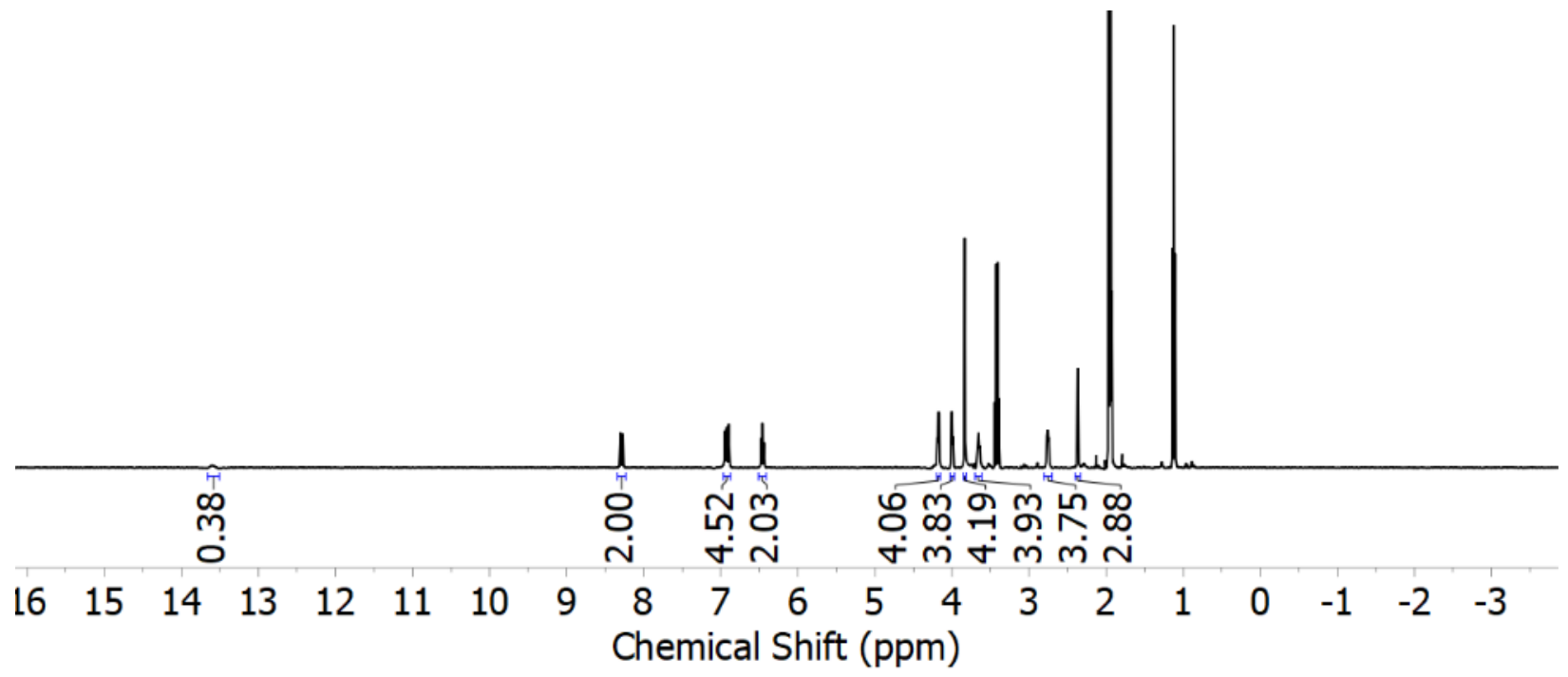

Figure S2. ${ }^{1} \mathrm{H}$ NMR spectrum $\left(400 \mathrm{MHz}, \mathrm{CD}_{3} \mathrm{CN}\right)$ of $\mathbf{L}^{\text {salben}} \mathbf{H}_{2} \mathbf{B a}$. 


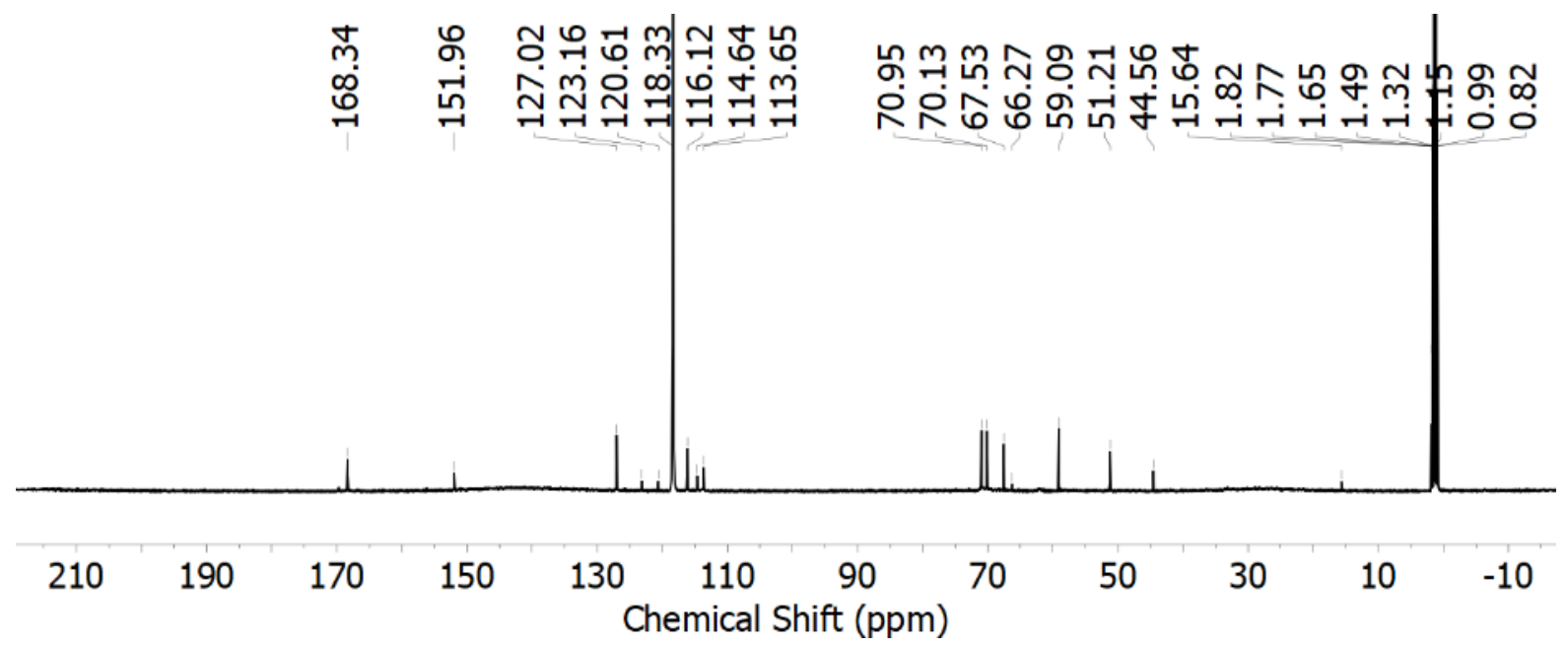

Figure S3. ${ }^{13} \mathrm{C}\left\{{ }^{1} \mathrm{H}\right\}$ NMR spectrum $\left(126 \mathrm{MHz}, \mathrm{CD}_{3} \mathrm{CN}\right)$ of $\mathbf{L}^{\text {salben }} \mathbf{H}_{2} \mathbf{B a}$.

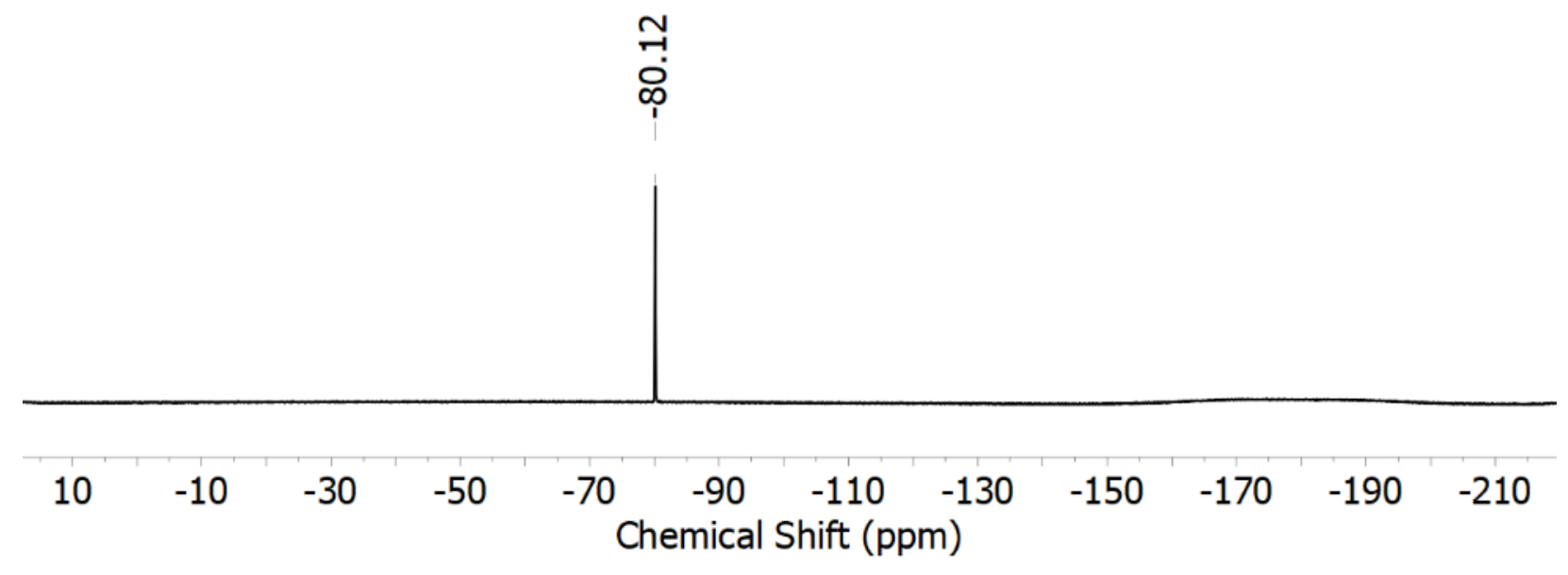

Figure S4. ${ }^{19} \mathrm{~F}$ NMR spectrum $\left(376 \mathrm{MHz}, \mathrm{CD}_{3} \mathrm{CN}\right)$ of $\mathbf{L}^{\text {salben}} \mathbf{H}_{2} \mathbf{B a}$. 


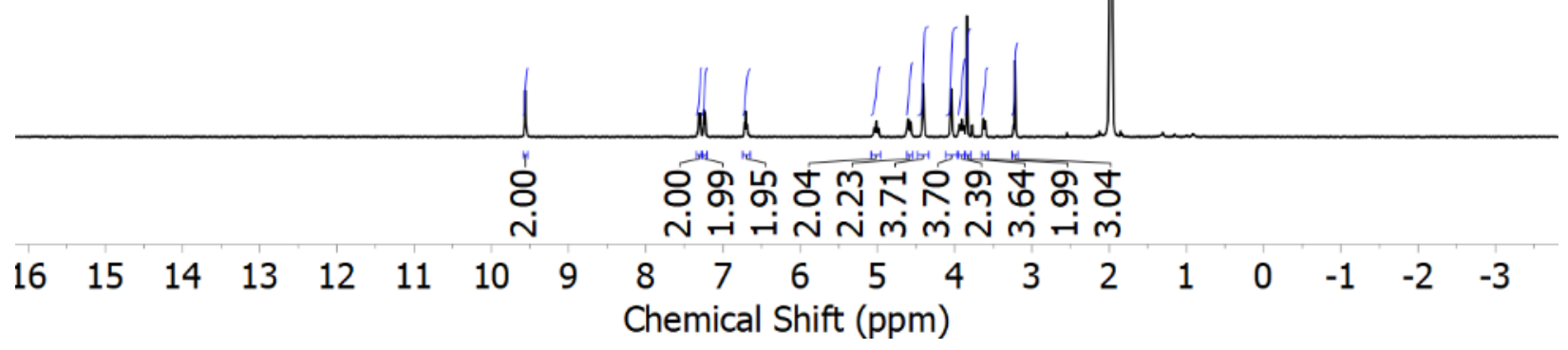

Figure S5. ${ }^{1} \mathrm{H}$ NMR spectrum $\left(500 \mathrm{MHz}, \mathrm{CD}_{3} \mathrm{CN}\right)$ of $\mathbf{L}^{\text {salben }} \mathbf{U O}_{2}$. 


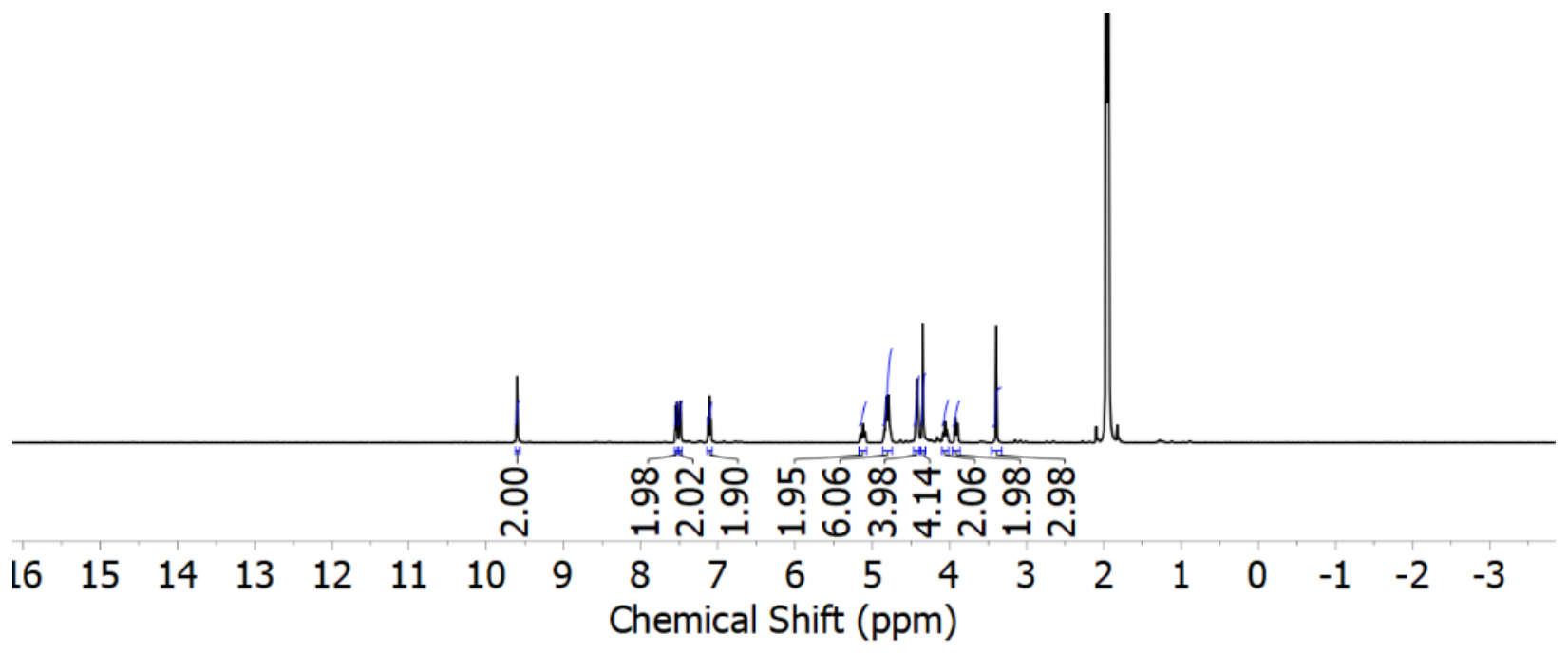

Figure S6. ${ }^{1} \mathrm{H}$ NMR spectrum $\left(500 \mathrm{MHz}, \mathrm{CD}_{3} \mathrm{CN}\right)$ of $\mathbf{L}^{\text {salben }} \mathbf{U} \mathbf{O}_{2} \mathbf{K}$.

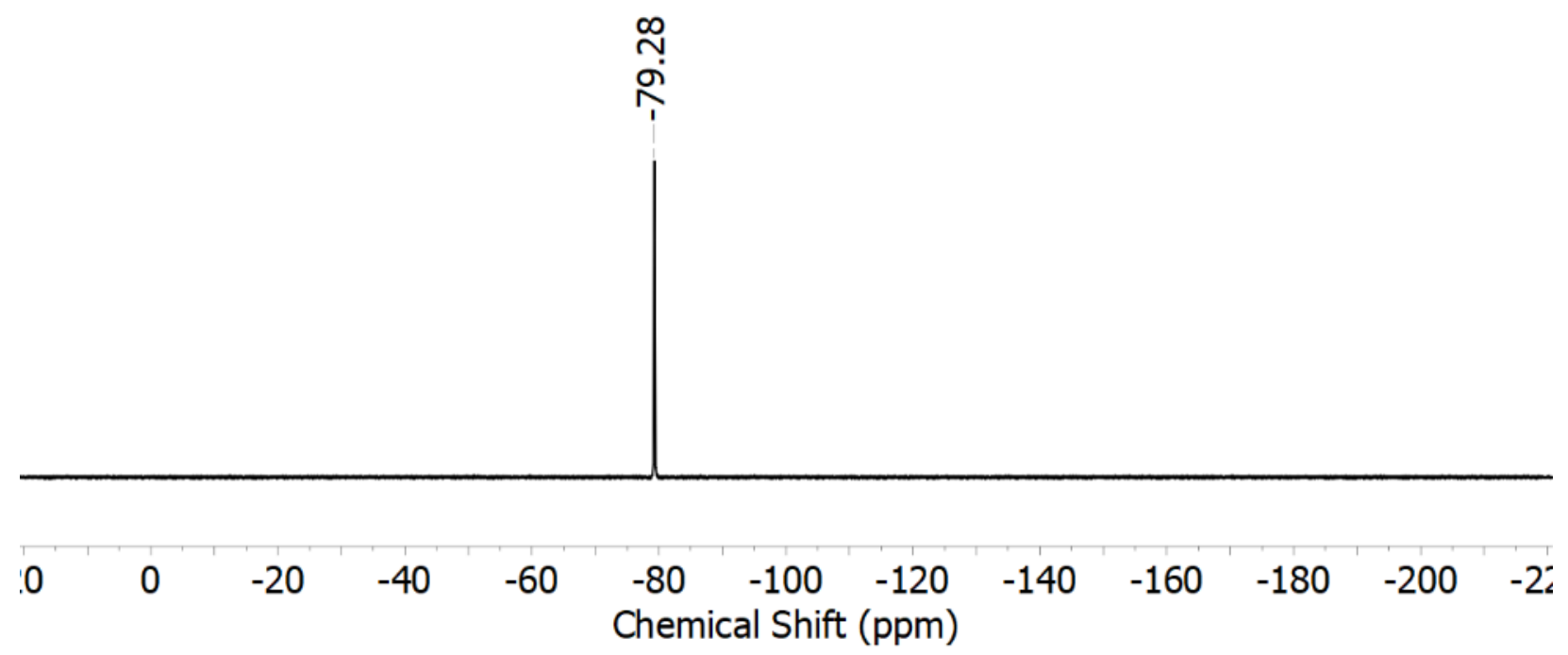

Figure S7. ${ }^{19} \mathrm{~F}$ NMR spectrum $\left(376 \mathrm{MHz}, \mathrm{CD}_{3} \mathrm{CN}\right)$ of $\mathbf{L}^{\text {salben }} \mathbf{U O}_{2} \mathbf{K}$. 


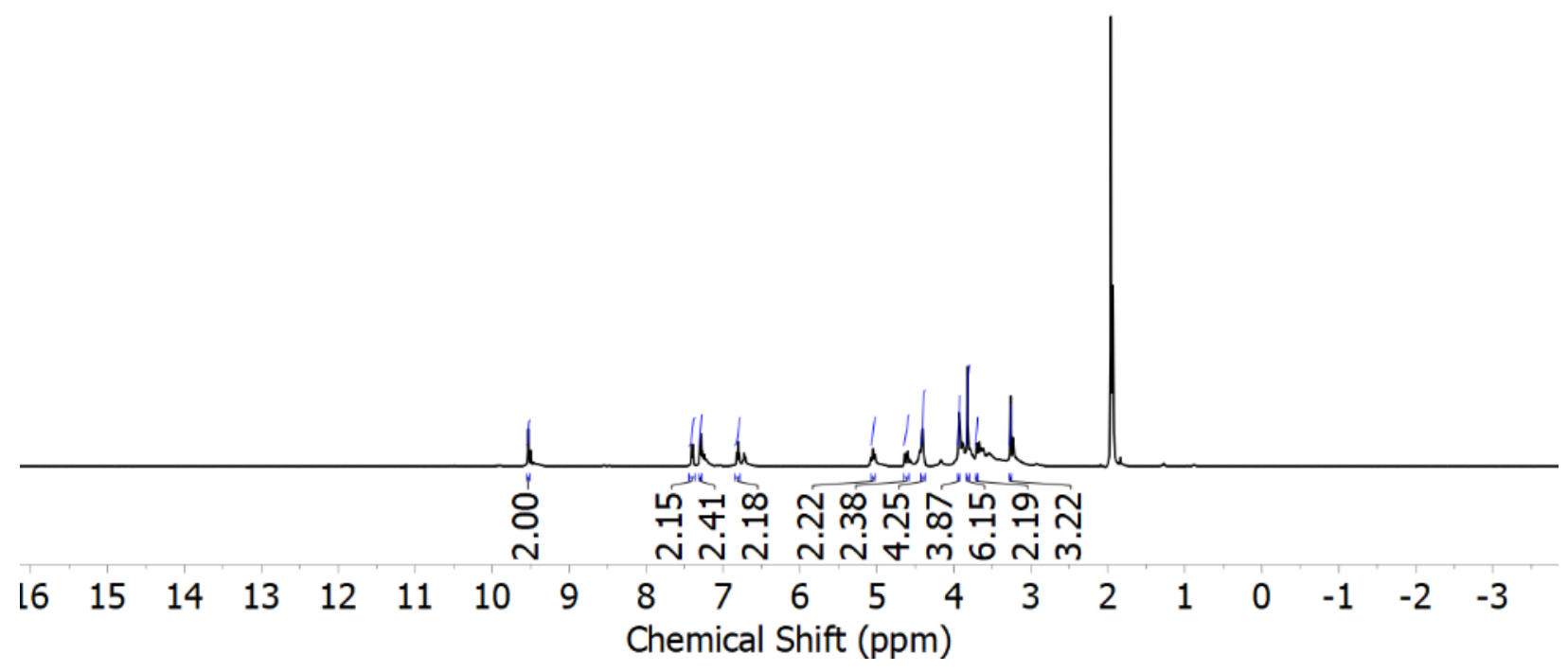

Figure S8. ${ }^{1} \mathrm{H}$ NMR spectrum $\left(500 \mathrm{MHz}, \mathrm{CD}_{3} \mathrm{CN}\right)$ of $\mathbf{L}^{\text {salben }} \mathbf{U O}_{2} \mathbf{N a}$.

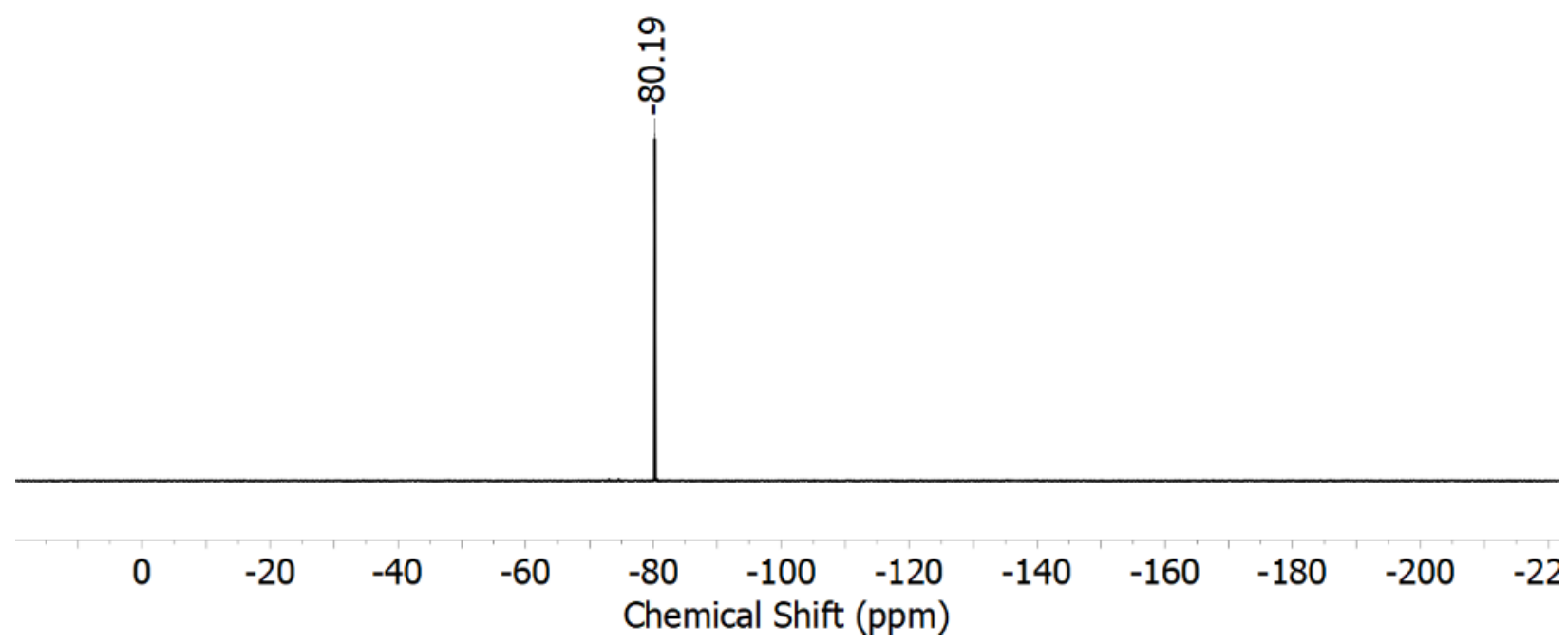

Figure S9. ${ }^{19} \mathrm{~F}$ NMR spectrum $\left(376 \mathrm{MHz}, \mathrm{CD}_{3} \mathrm{CN}\right)$ of $\mathbf{L}^{\text {salben }} \mathbf{U O}_{2} \mathbf{N a}$. 


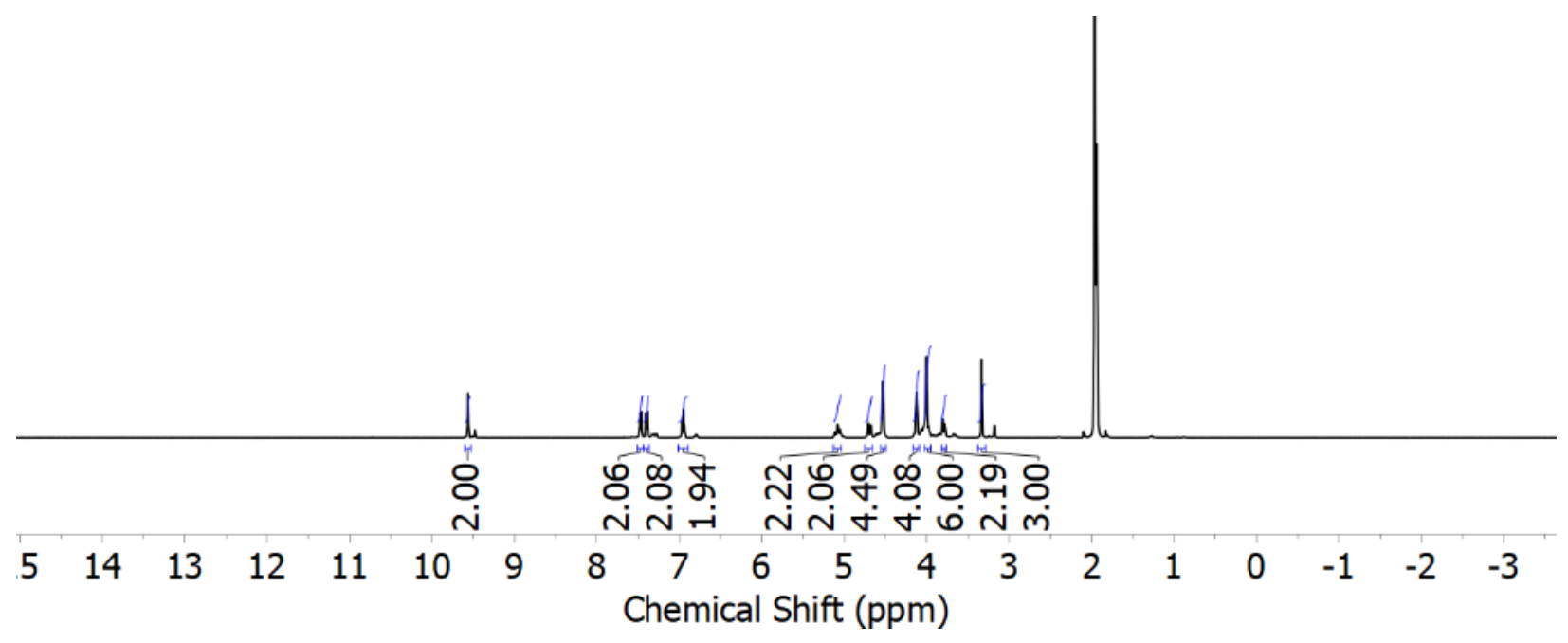

Figure S10. ${ }^{1} \mathrm{H}$ NMR spectrum $\left(500 \mathrm{MHz}, \mathrm{CD}_{3} \mathrm{CN}\right)$ of $\mathbf{L}^{\text {salben }} \mathbf{U O}_{2} \mathbf{C a}$.

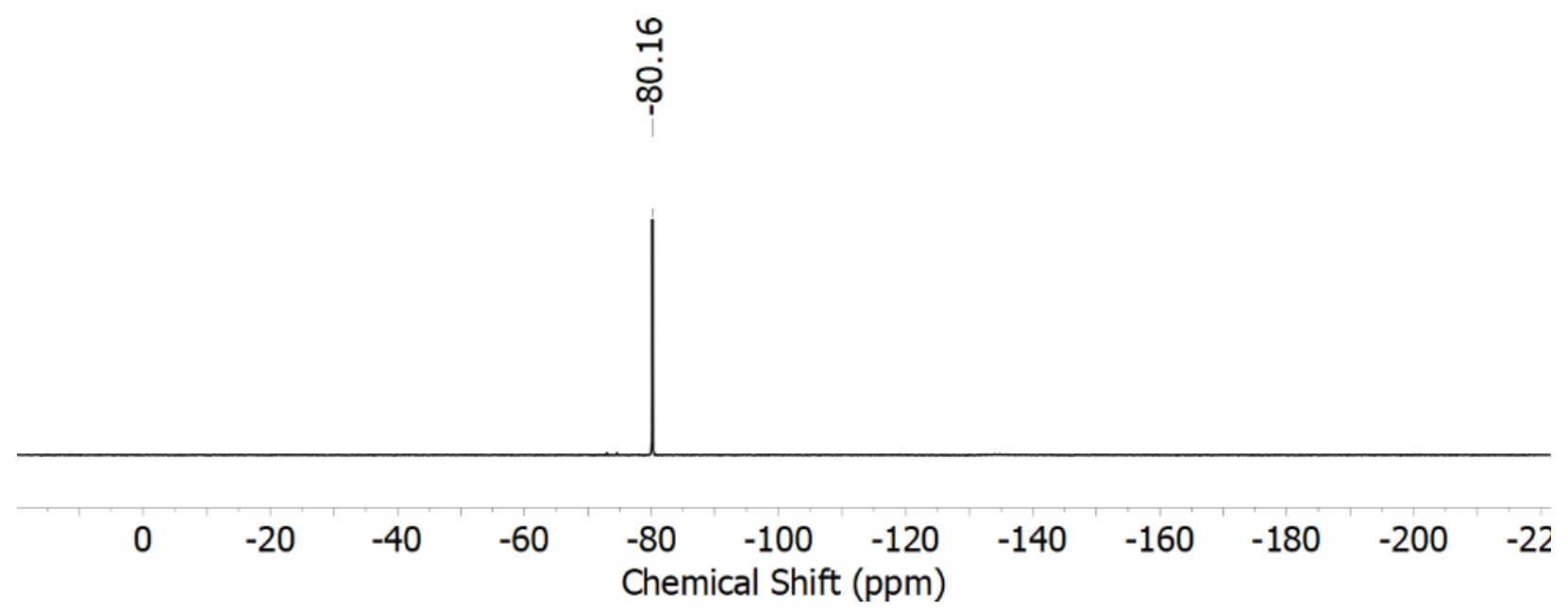

Figure S11. ${ }^{19} \mathrm{~F}$ NMR spectrum $\left(376 \mathrm{MHz}, \mathrm{CD}_{3} \mathrm{CN}\right)$ of $\mathbf{L}^{\text {salben }} \mathbf{U O}_{2} \mathbf{C a}$. 


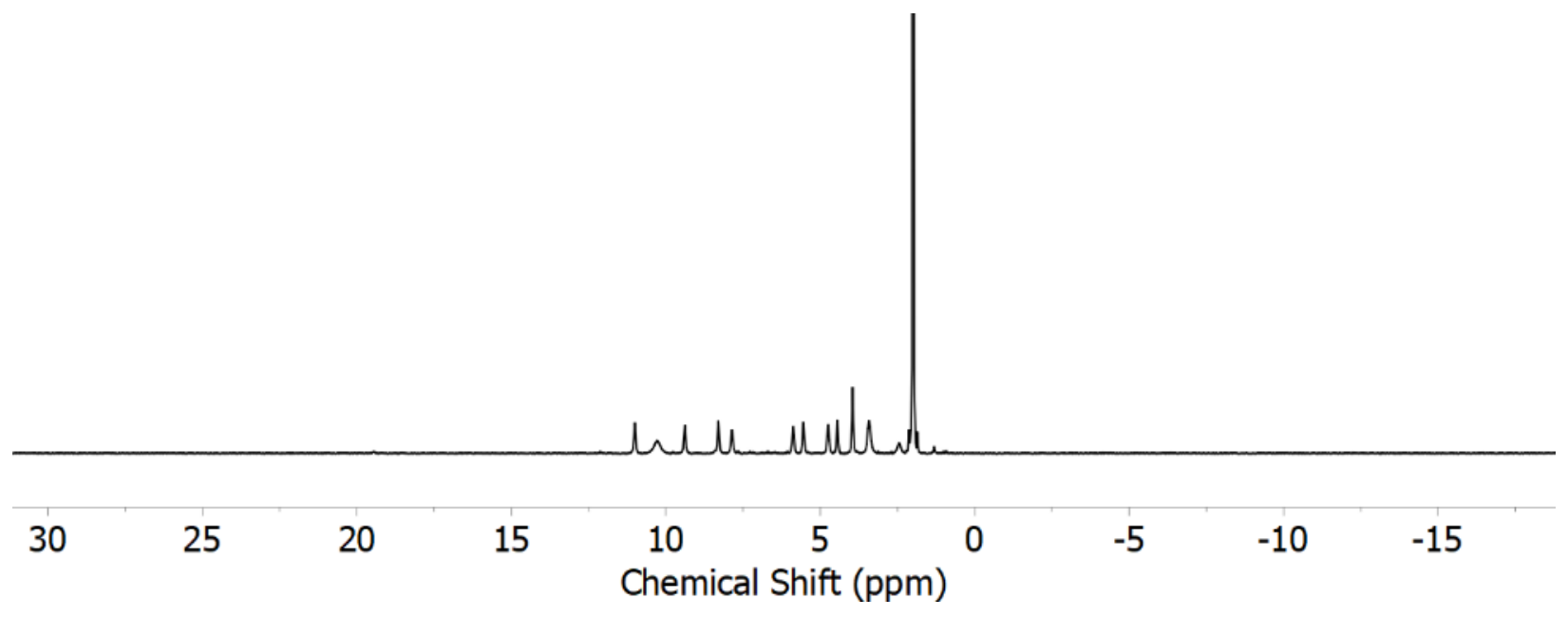

Figure S12. ${ }^{1} \mathrm{H}$ NMR spectrum $\left(500 \mathrm{MHz}, \mathrm{CD}_{3} \mathrm{CN}\right)$ of $\mathbf{L}^{\text {salben }} \mathbf{U O}_{2} \mathbf{N d}$.

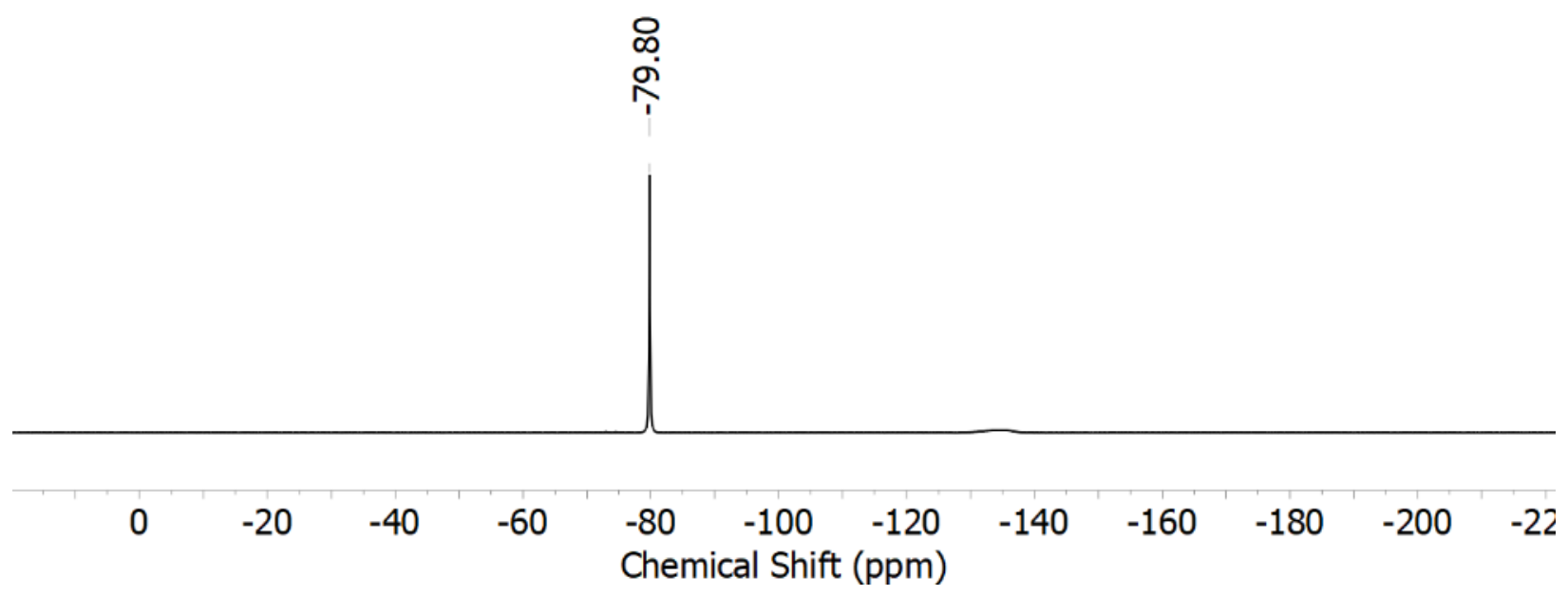

Figure S13. ${ }^{19} \mathrm{~F}$ NMR spectrum $\left(376 \mathrm{MHz}, \mathrm{CD}_{3} \mathrm{CN}\right)$ of $\mathbf{L}^{\text {salben }} \mathbf{U O}_{2} \mathbf{N d}$. 


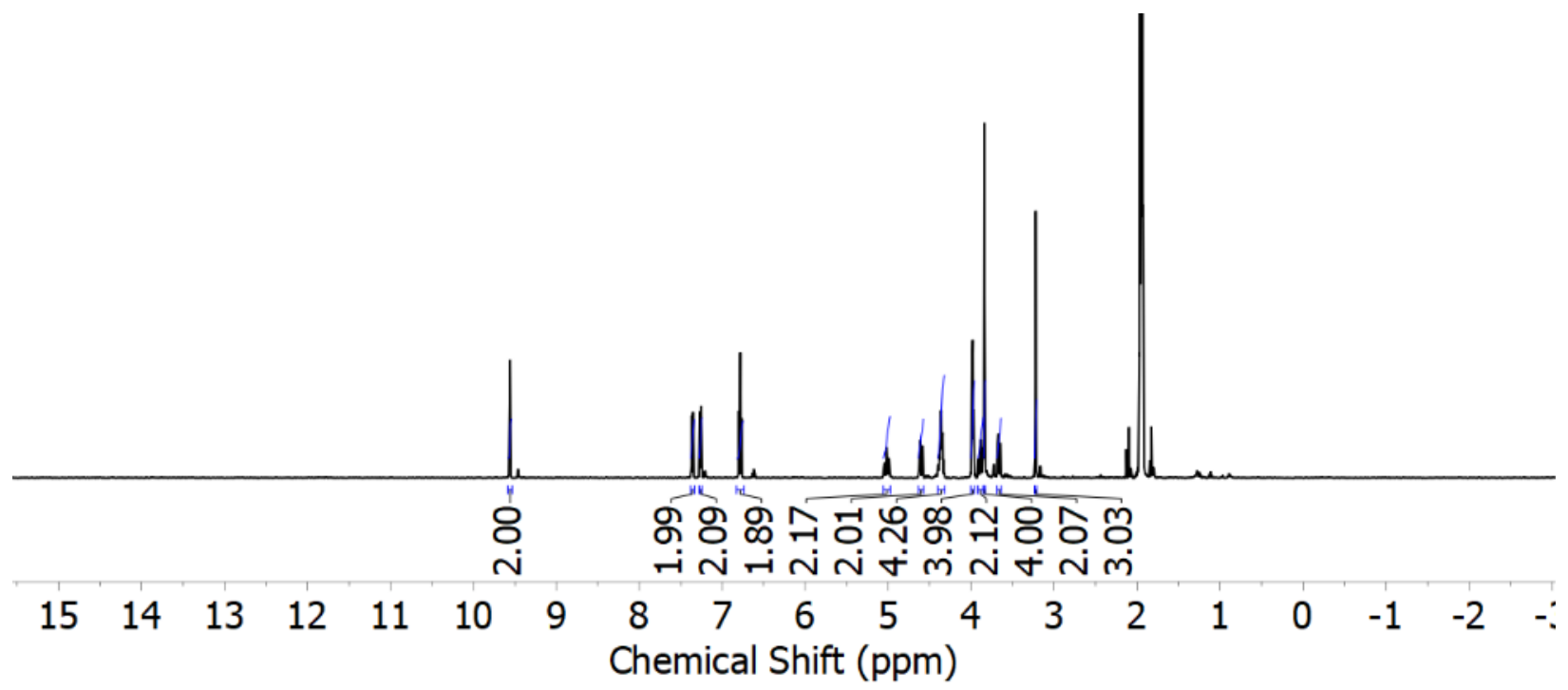

Figure S14. ${ }^{1} \mathrm{H}$ NMR spectrum $\left(400 \mathrm{MHz}, \mathrm{CD}_{3} \mathrm{CN}\right)$ of $\mathbf{L}^{\text {salben }} \mathbf{U O}_{2} \mathbf{Y}$.

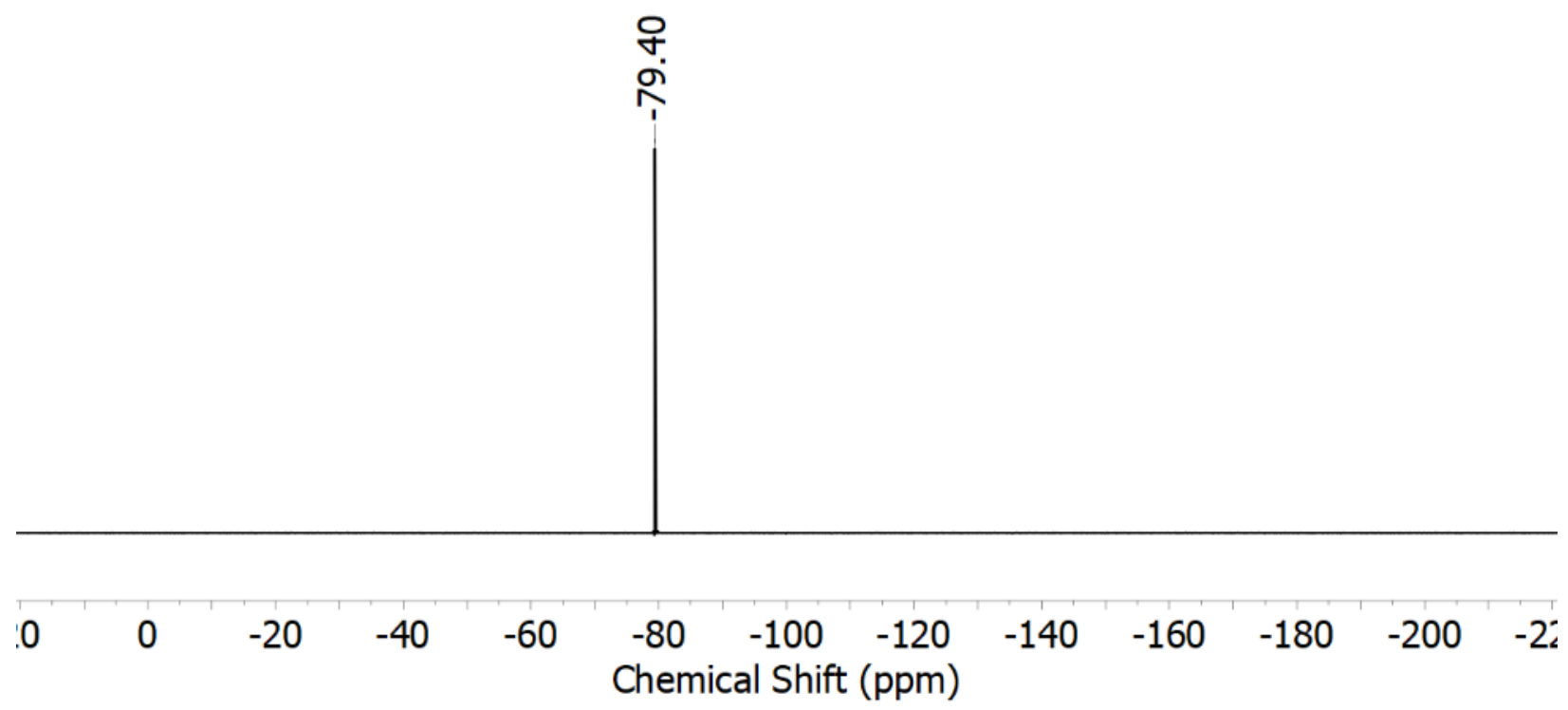

Figure S15. ${ }^{19} \mathrm{~F}$ NMR spectrum $\left(376 \mathrm{MHz}, \mathrm{CD}_{3} \mathrm{CN}\right)$ of $\mathbf{L}^{\text {salben}} \mathbf{U O}_{2} \mathbf{Y}$. 


\section{Features of the uranyl $\left(\mathrm{UO}_{2}{ }^{2+}\right)$ containing complexes}

These complexes are only slightly soluble in common solvents such as $\mathrm{CH}_{3} \mathrm{CN}$ and THF which precludes collection of conclusive ${ }^{13} \mathrm{C}\left\{{ }^{1} \mathrm{H}\right\}$ NMR. Furthermore, as observed in crystallographic data (Figure S51 and S58), there are two possible orientations of the trialkyl amine bridge that forms a portion of the pentadentate site for uranyl binding. Upon binding of Lewis acids in the crown ether cavity, distortion and anticipated rigidification of the trialkyl amine bridge gives rise to a uniform set of small satellite peaks (corresponding to ca. $10 \%$ population) associated with the minor isomer (Figure S8, S10 and S14). Additionally, we find all the compounds must be handled under dry inert atmosphere likely due to both the high Lewis acidity of the redox-inactive cations as well as the strongly Lewis acidic nature of the $\mathrm{UO}_{2}{ }^{2+}\left(\mathrm{p} K_{\mathrm{a}}\right.$ $=5.8$ ) itself. $^{1}$ 


\section{Electronic Absorption Spectra}

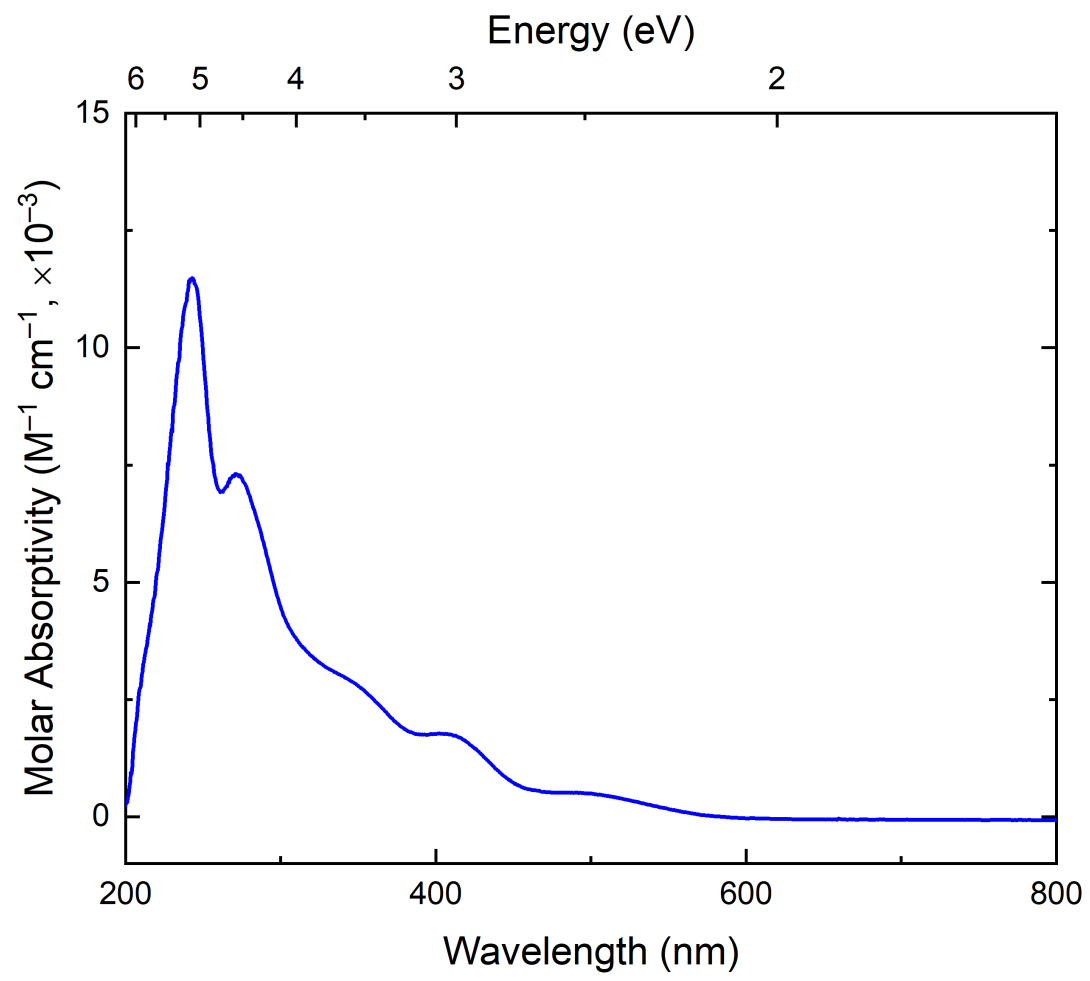

Figure S16. Electronic absorption spectrum of $\mathbf{L}^{\text {salben }} \mathbf{U O}_{2}$ in $\mathrm{CH}_{3} \mathrm{CN}$.

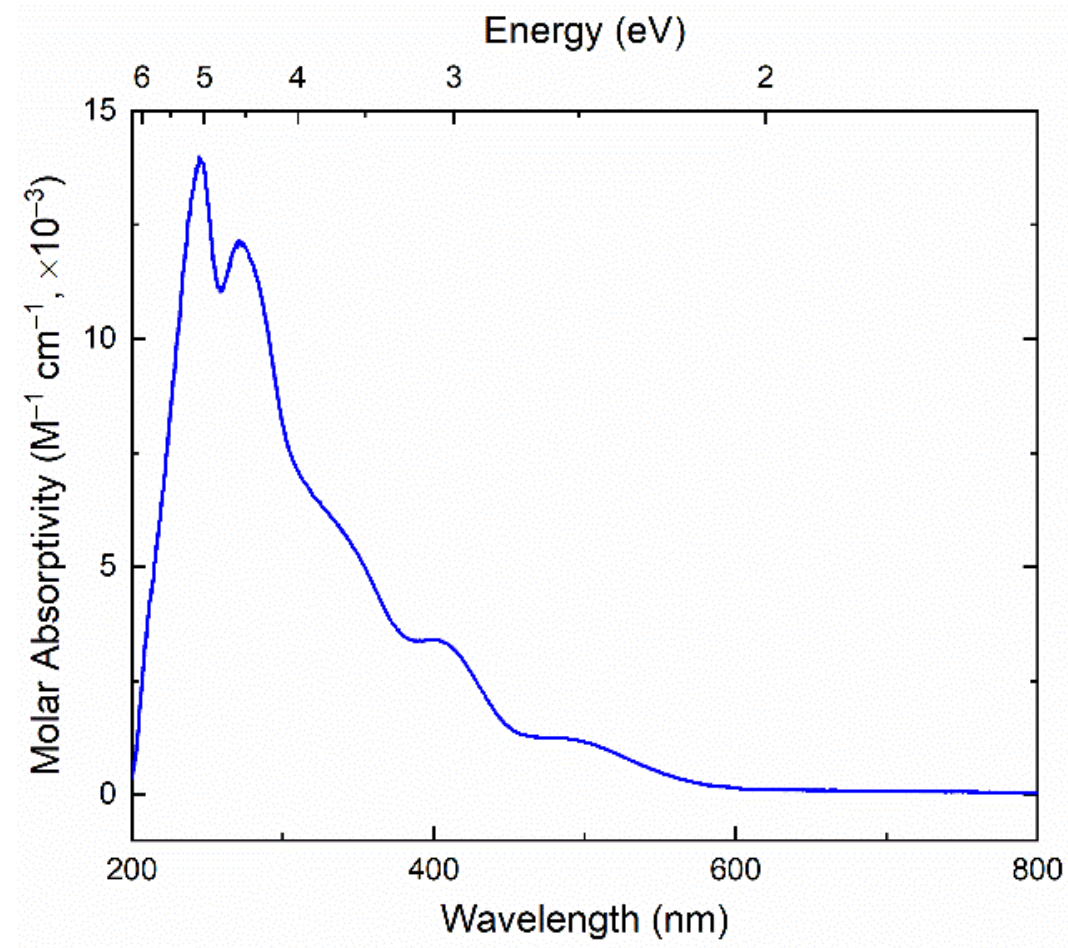

Figure S17. Electronic absorption spectrum of $\mathbf{L}^{\text {salben }} \mathbf{U O}_{2} \mathbf{K}$ in $\mathrm{CH}_{3} \mathrm{CN}$. 

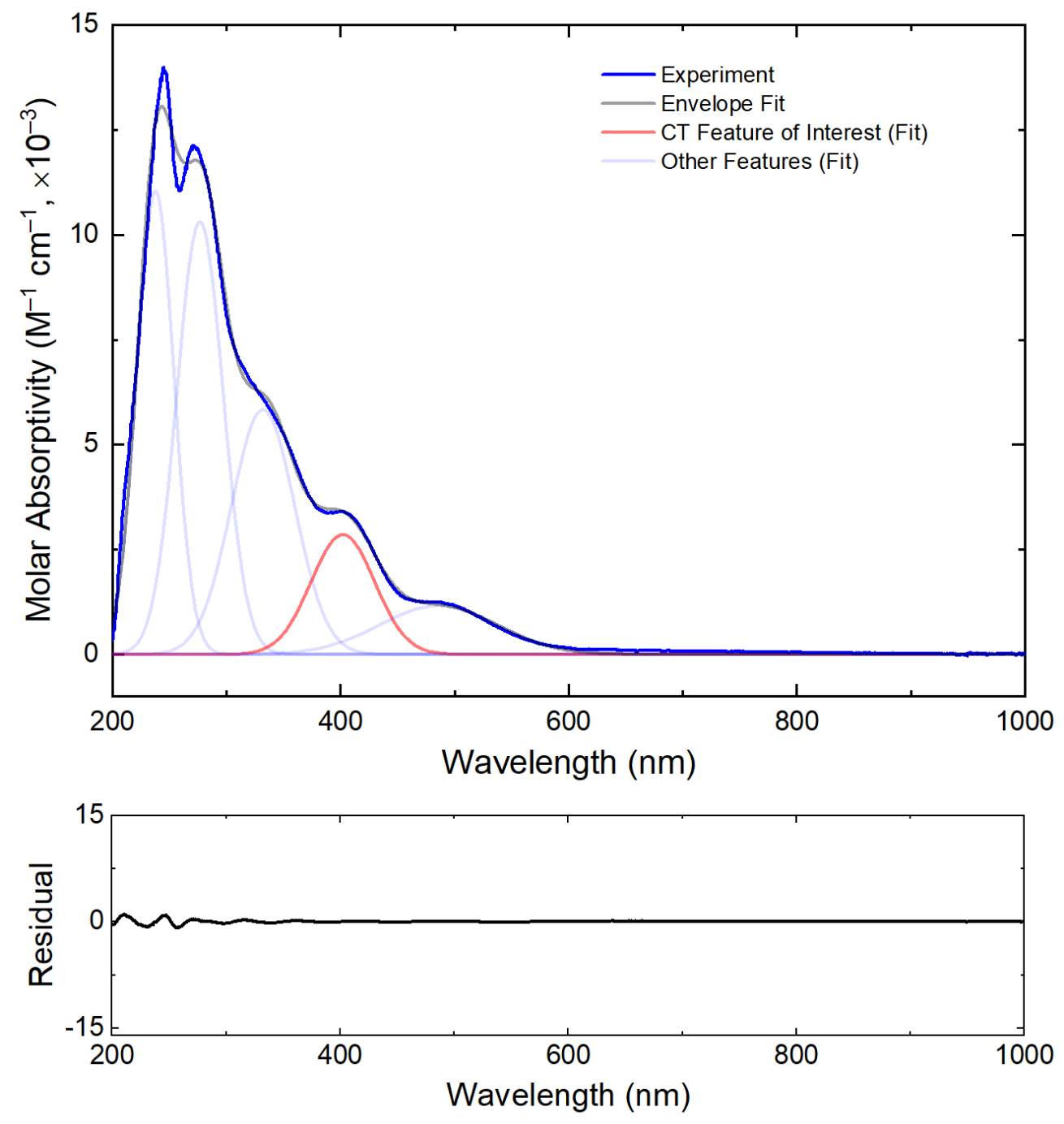

Figure S18. Peak Deconvolution of the Electronic absorption spectrum of $\mathbf{L}^{\text {salben }} \mathbf{U O}_{2} \mathbf{K}$ in $\mathrm{CH}_{3} \mathrm{CN}$ using Gaussian fit method. The trace in red displays the charge transfer (CT) band of interest which was used to get the $\lambda_{\max }$ value. 


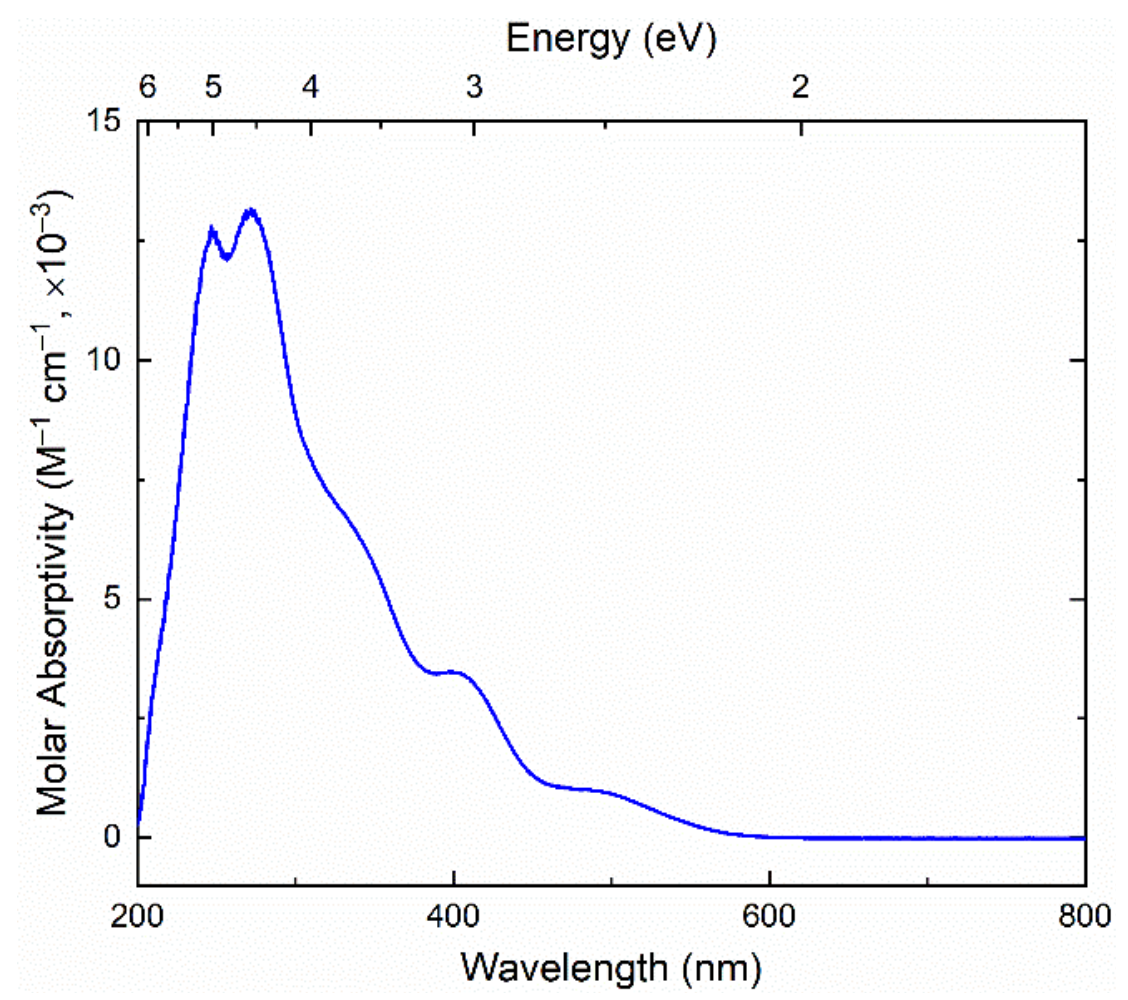

Figure S19. Electronic absorption spectrum of $\mathbf{L}^{\text {salben }} \mathbf{U} \mathbf{O}_{2} \mathbf{N a}$ in $\mathrm{CH}_{3} \mathrm{CN}$.

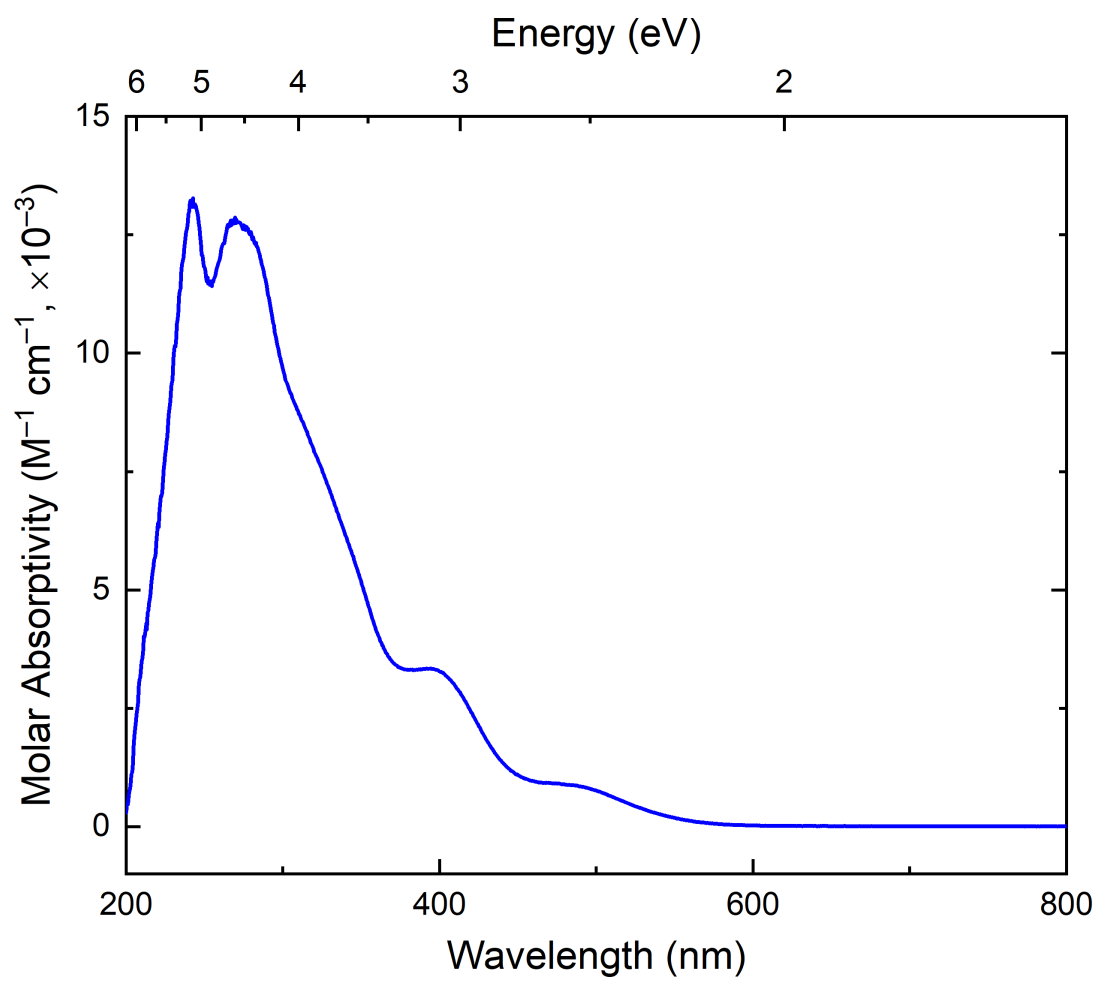

Figure S20. Electronic absorption spectrum of $\mathbf{L}^{\text {salben }} \mathbf{U O}_{2} \mathbf{C a}$ in $\mathrm{CH}_{3} \mathrm{CN}$. 


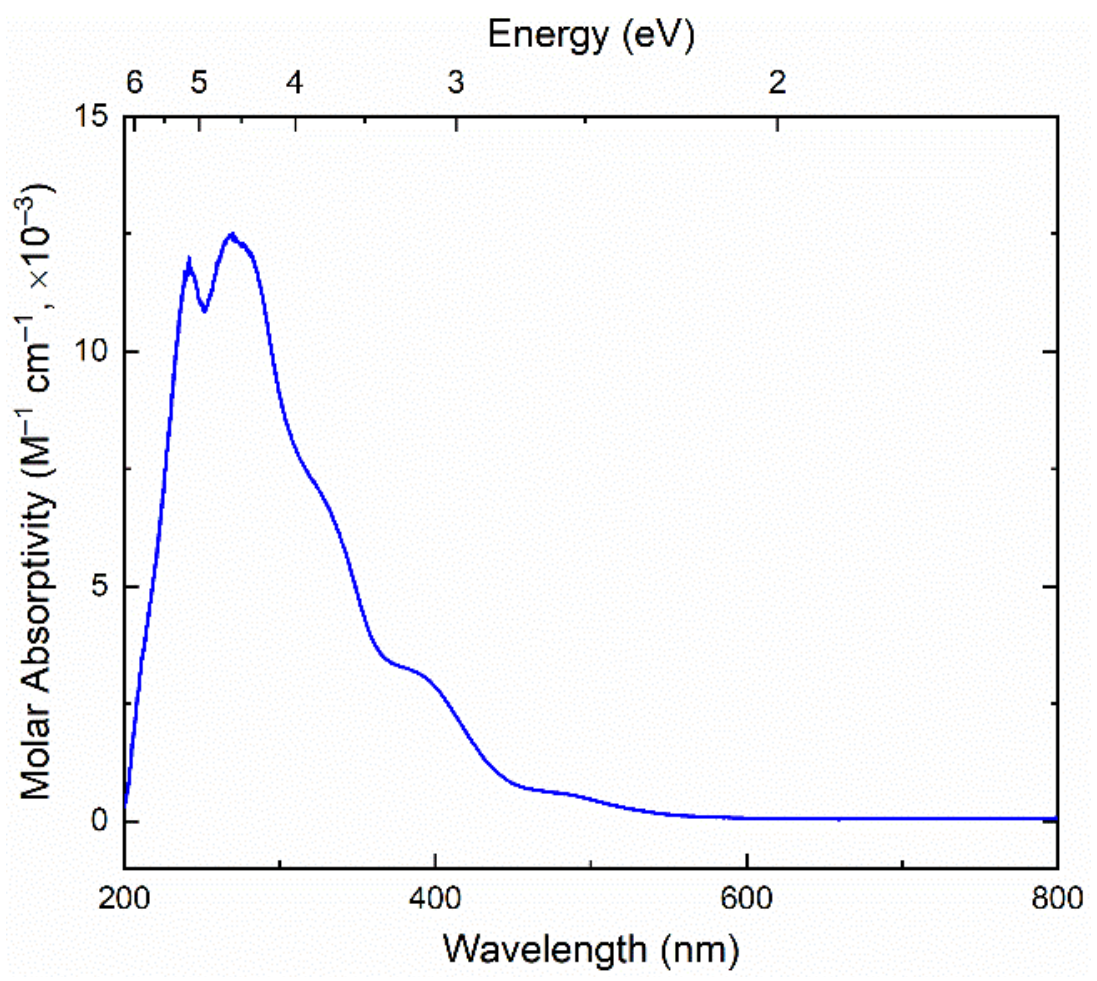

Figure S21. Electronic absorption spectrum of $\mathbf{L}^{\text {salben }} \mathbf{U O}_{2} \mathbf{N d}$ in $\mathrm{CH}_{3} \mathrm{CN}$

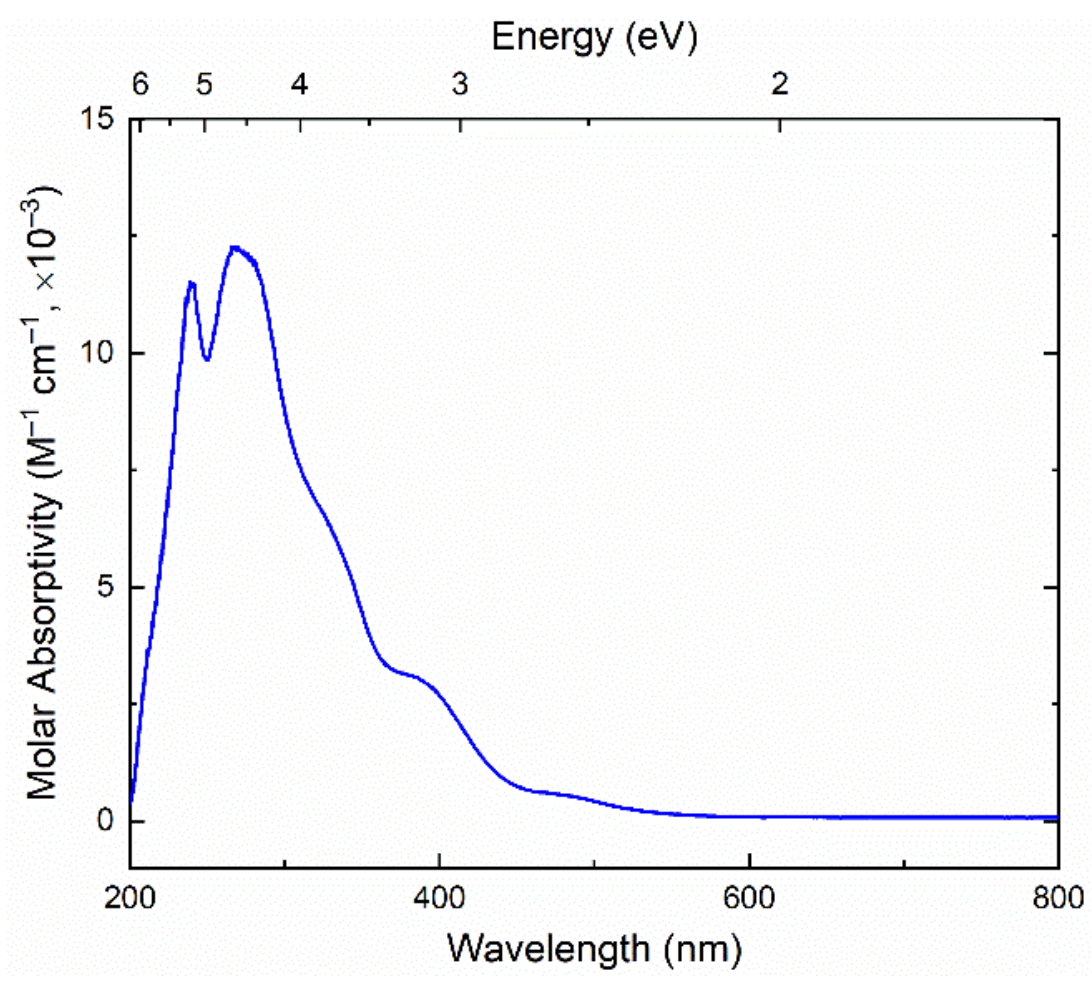

Figure S22. Electronic absorption spectrum of $\mathbf{L}^{\text {salben }} \mathbf{U O}_{2} \mathbf{Y}$ in $\mathrm{CH}_{3} \mathrm{CN}$ 


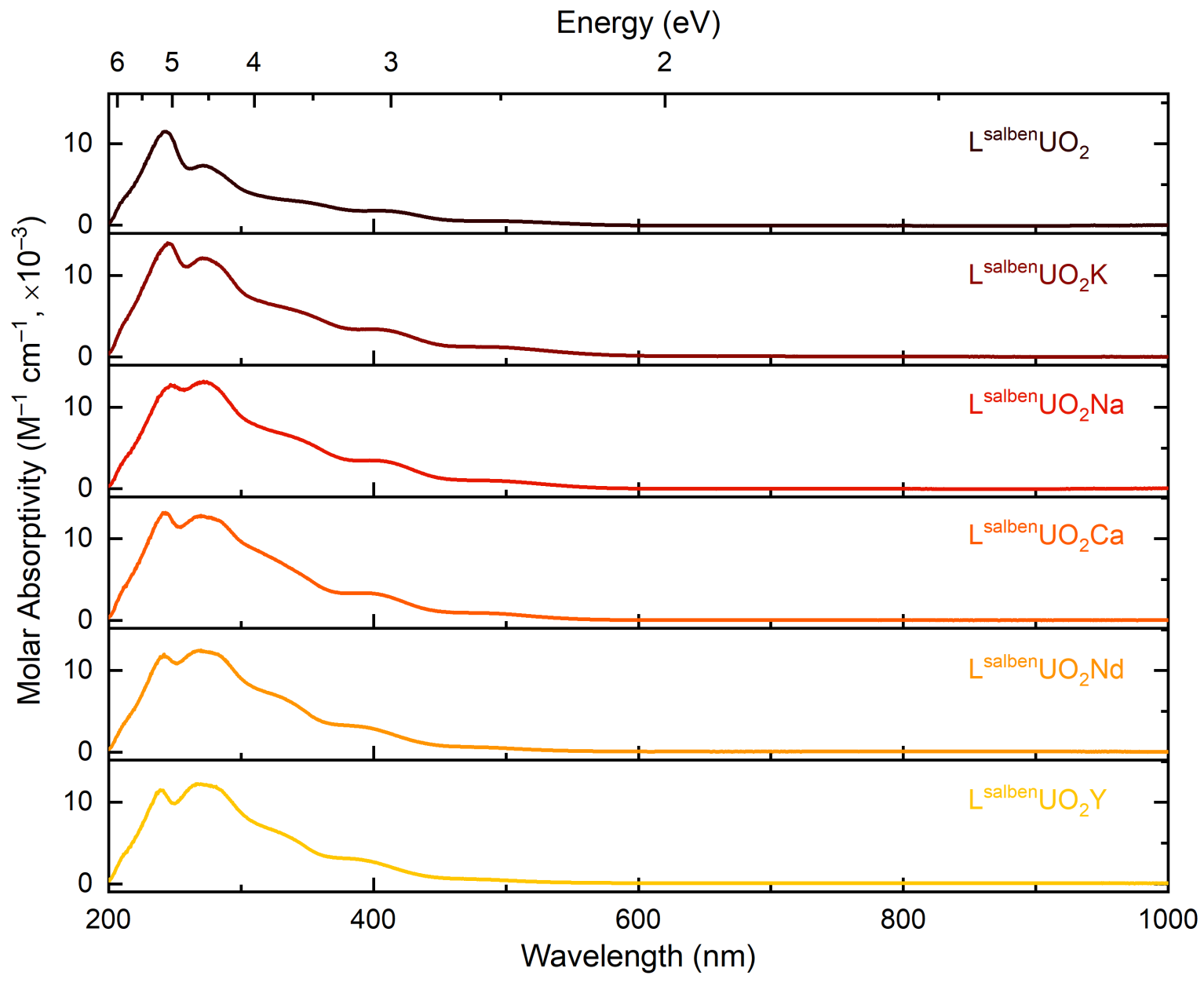

Figure S23. Stacked electronic absorption spectra of the $\mathbf{L}^{\text {salben }} \mathbf{U} \mathbf{O}_{2}$ and $\mathbf{L}^{\text {salben }} \mathbf{U} \mathbf{O}_{2} \mathbf{M}$ complexes focusing on $\pi-\pi^{*}$ transitions. 


\section{Electrochemistry}

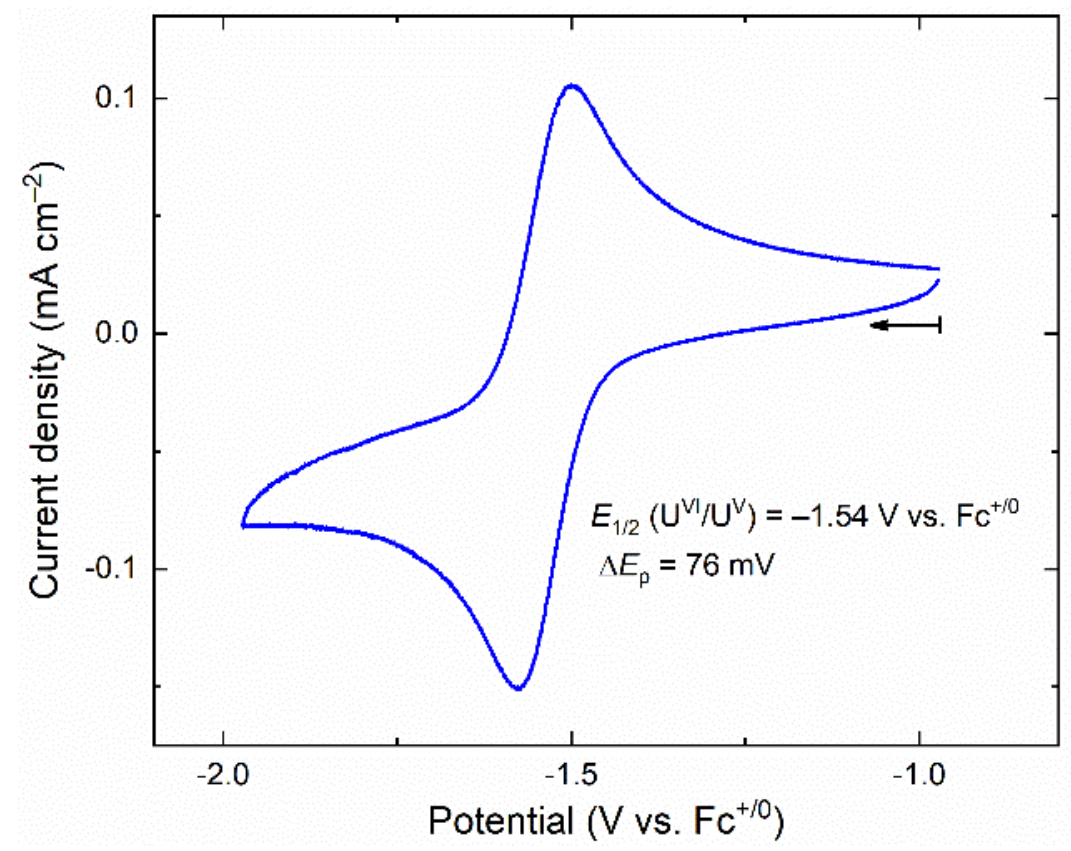

Figure S24. Cyclic voltammetry data for $\mathbf{L}^{\text {salben}} \mathbf{U O}_{2}$ in $\mathrm{CH}_{3} \mathrm{CN}\left(0.1 \mathrm{M}\left[{ }^{\mathrm{n}} \mathrm{Bu}_{4} \mathrm{~N}\right]^{+}\left[\mathrm{PF}_{6}\right]^{-}, 100\right.$ $\mathrm{mV} / \mathrm{s}$ ).
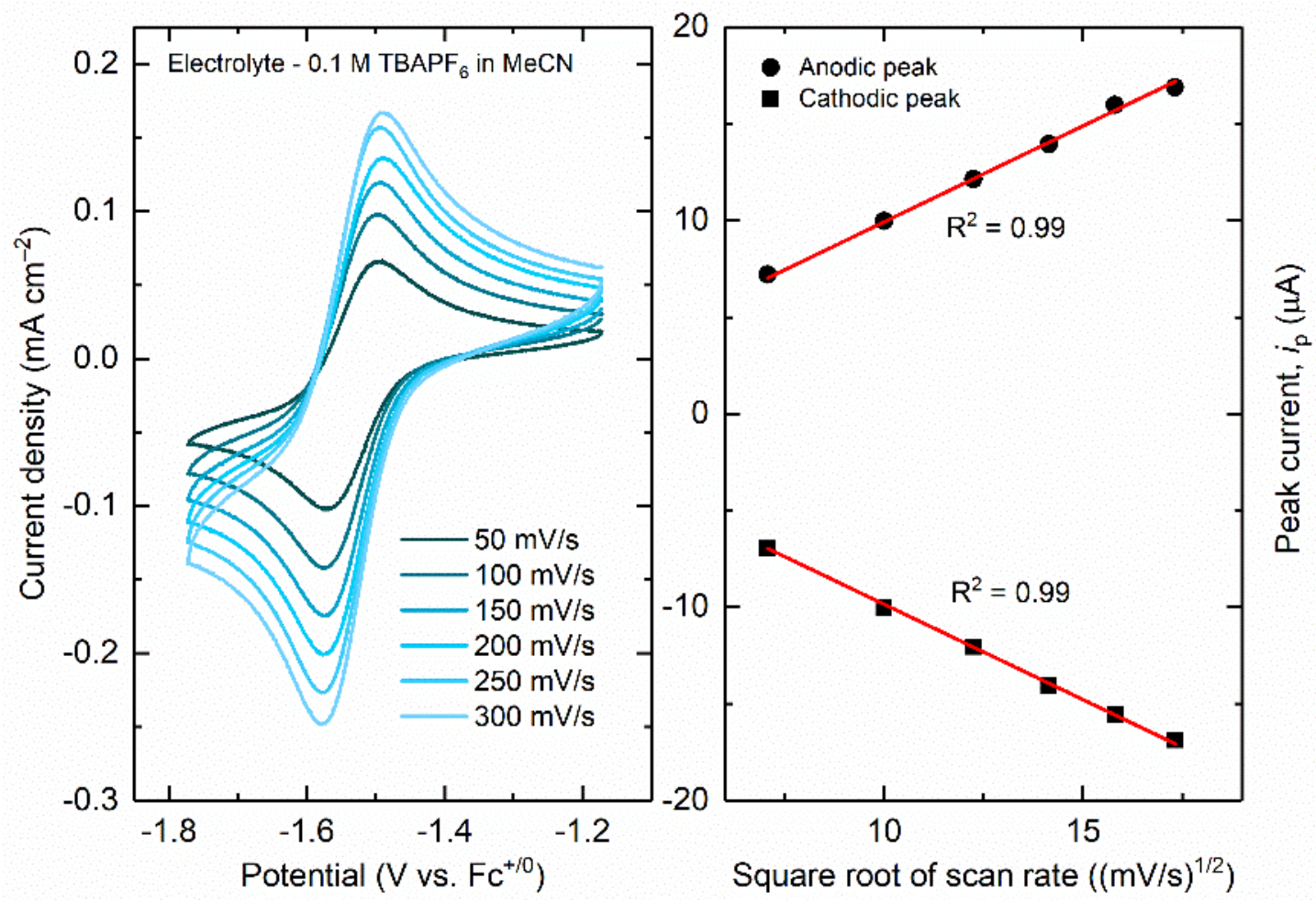

Figure S25. Left panel: scan rate dependence data for $\mathbf{L}^{\text {salben}} \mathbf{U} \mathbf{O}_{2}$. Right panel: plot of peak current density vs. (scan rate) ${ }^{1 / 2}$, demonstrating the diffusional nature of the oxidized and reduced species involved in the redox couple in question. 

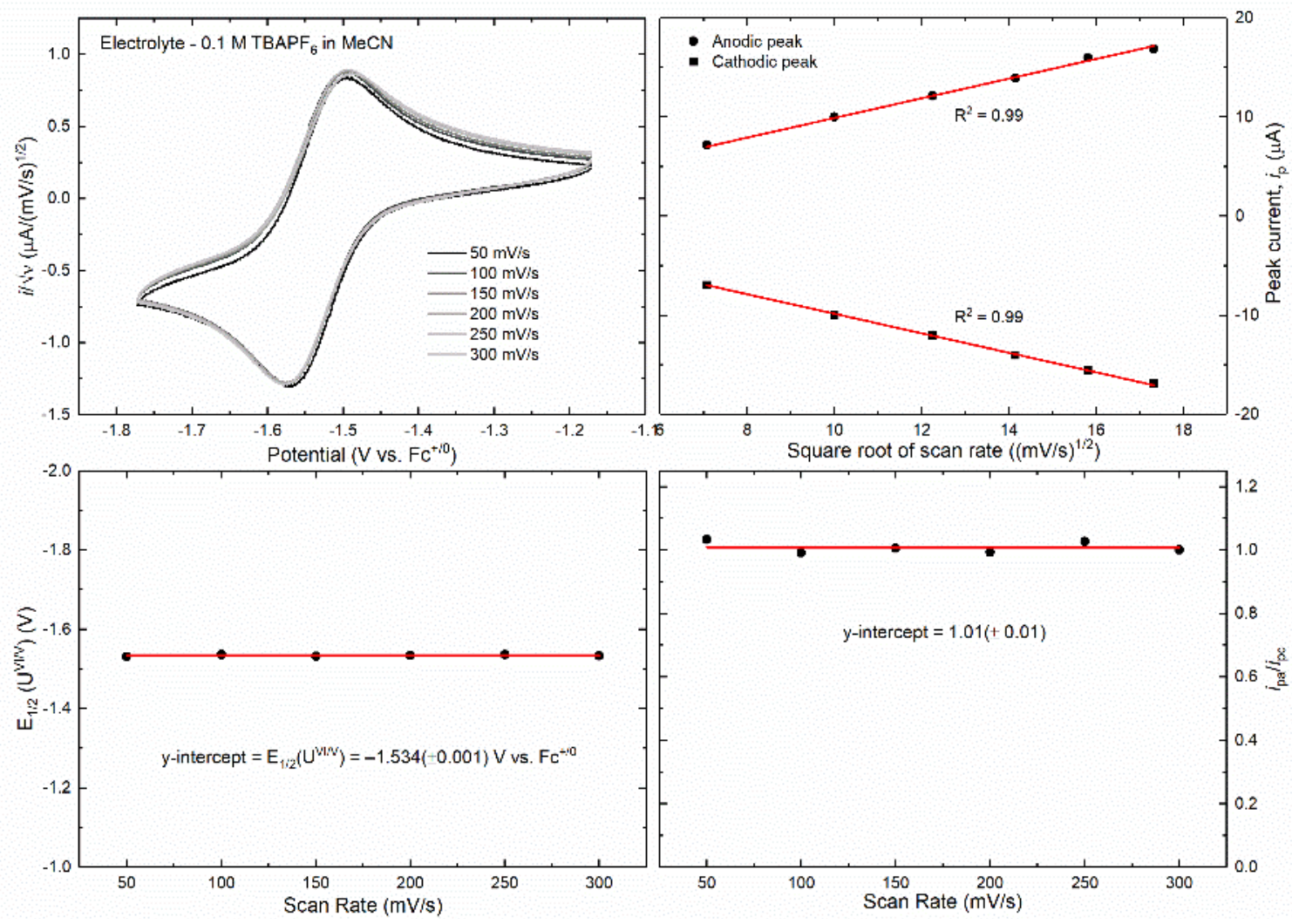

Figure S26. Analysis of electrochemical data confirming chemical reversibility of reduction of $\mathbf{L}^{\text {salben}} \mathbf{U} \mathbf{O}_{2}$. The chemically reversible nature of electron transfer to this compound is confirmed $^{2}$ by the scan rate-independent $E_{1 / 2}$ value (lower left panel) as well as the scan rate-independent ratio of anodic to cathodic peak currents equal to $1.01( \pm 0.01)$ (lower right panel). This ratio indicates that electrochemically generated $U^{V}$ is recollected to regenerate the $\mathrm{U}^{\mathrm{VI}}$ starting complex with unity efficiency. These data were tabulated from background corrected current-voltage curves derived from a spline-fit procedure available in the literature $^{3}$ which approximates the current-time (Cottrell-like) behavior of a diffusional process in cyclic voltammetry. ${ }^{4}$ These spline background-corrected data also effectively remove contributions from non-Faradaic currents at higher scan rate with the result that current-voltage curves normalized by the square root of scan rate overlap with high similarity (upper left panel). Consequently, the spline background-corrected anodic and cathodic peak currents tightly obey the expected dependence on the square root of scan rate required by the Randles-Ševčik equation for freely diffusing species (upper right panel). ${ }^{5,6}$ This tight agreement includes the expected $y$-intercept value of 0 within the error of the data $(0.35 \pm 0.32 ;-0.26 \pm 0.19)$. As the scan rate range accessible with our working electrodes $(A=$ $0.09 \mathrm{~cm}^{2}$ ) is not especially wide, the spline background-corrected data plotted to check agreement with the Randles-Ševčik equation do not differ greatly from their nonbackground-corrected counterparts (Figure S23). 


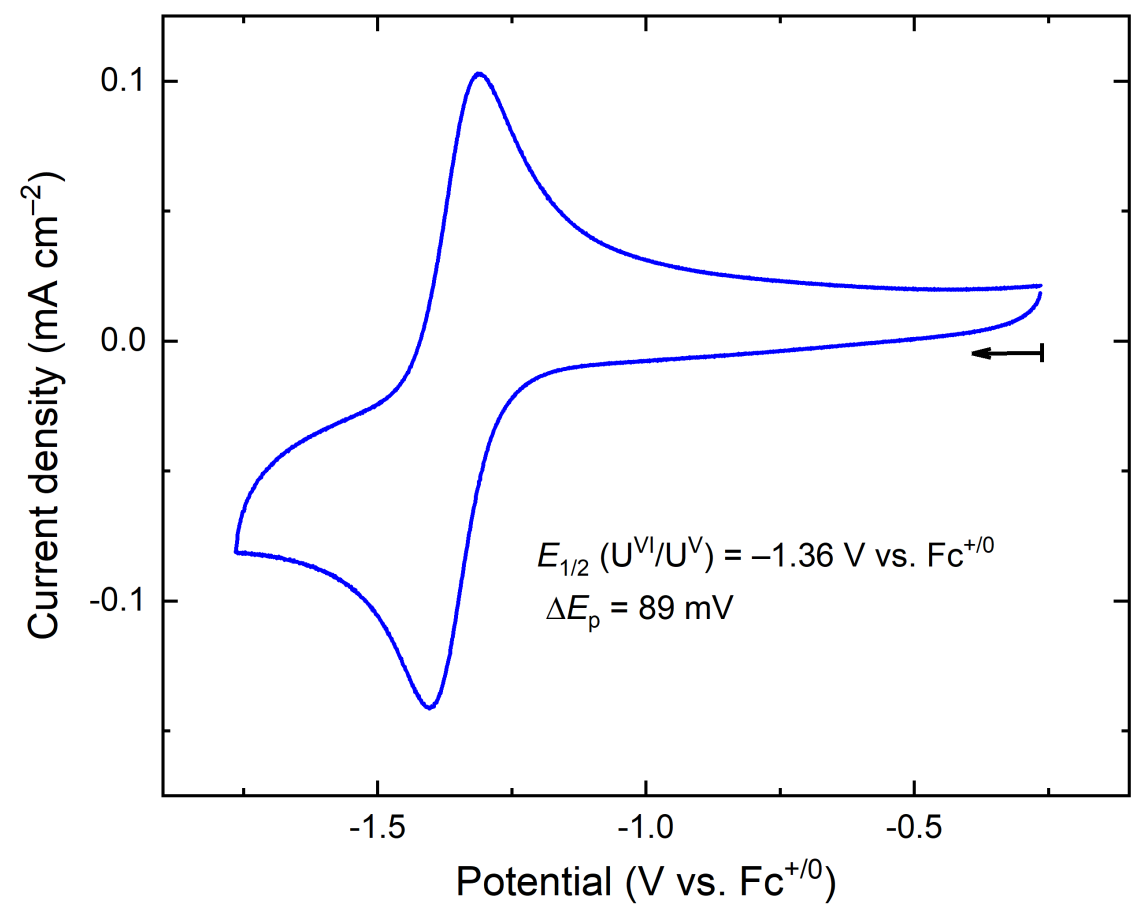

Figure S27. Cyclic voltammetry data for $\mathbf{L}^{\text {salben }} \mathbf{U O}_{2} \mathbf{K}$ in $\mathrm{CH}_{3} \mathrm{CN}\left(0.1 \mathrm{M}\left[{ }^{\mathrm{n}} \mathrm{Bu}_{4} \mathrm{~N}\right]^{+}\left[\mathrm{PF}_{6}\right]^{-}, 100\right.$ $\mathrm{mV} / \mathrm{s})$.
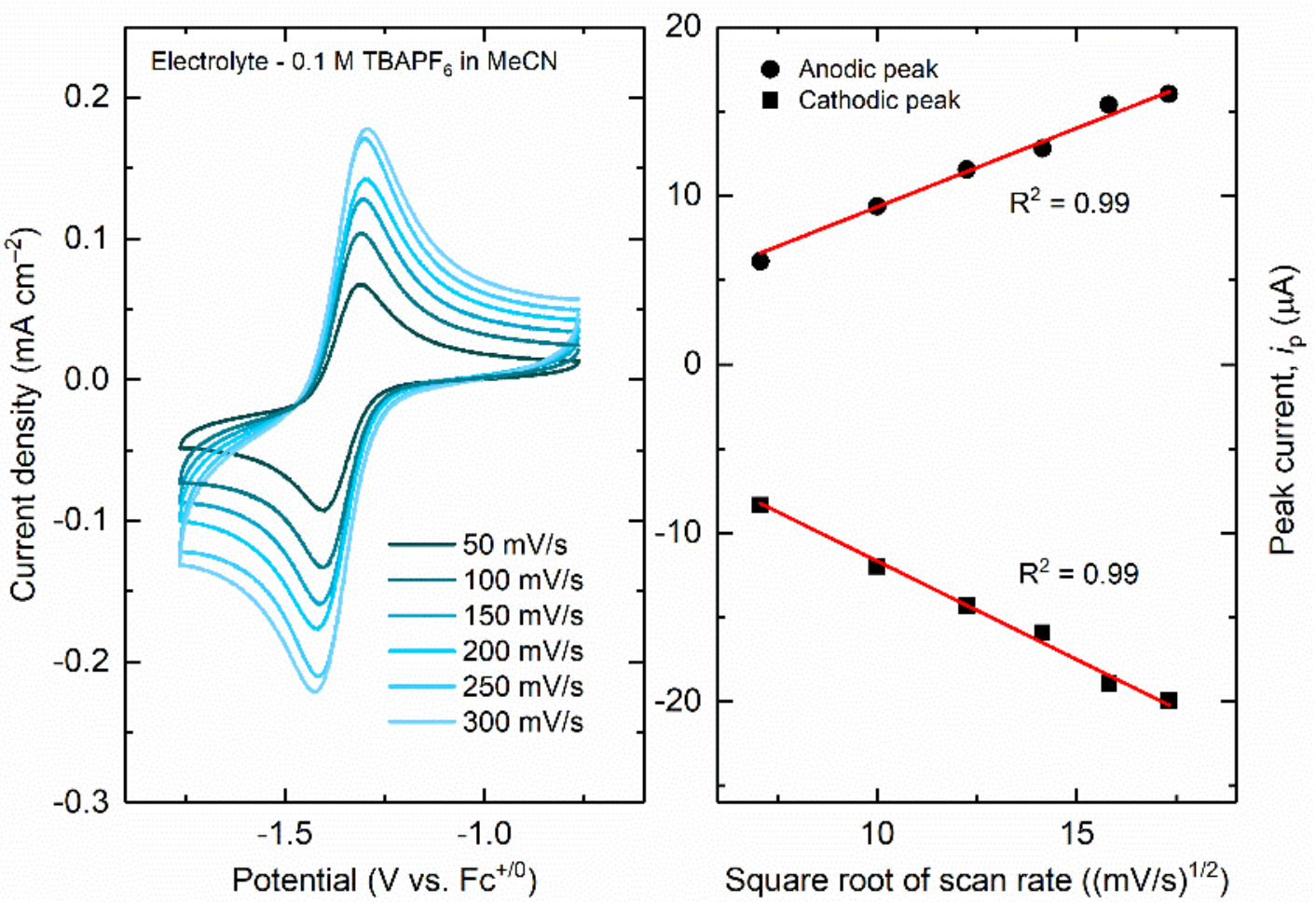

Figure S28. Left panel: scan rate dependence data for $\mathbf{L}^{\text {salben}} \mathbf{U} \mathbf{O}_{2} \mathbf{K}$. Right panel: plot of peak current density vs. (scan rate) $)^{1 / 2}$, demonstrating the diffusional nature of the oxidized and reduced species involved in the redox couple in question. 

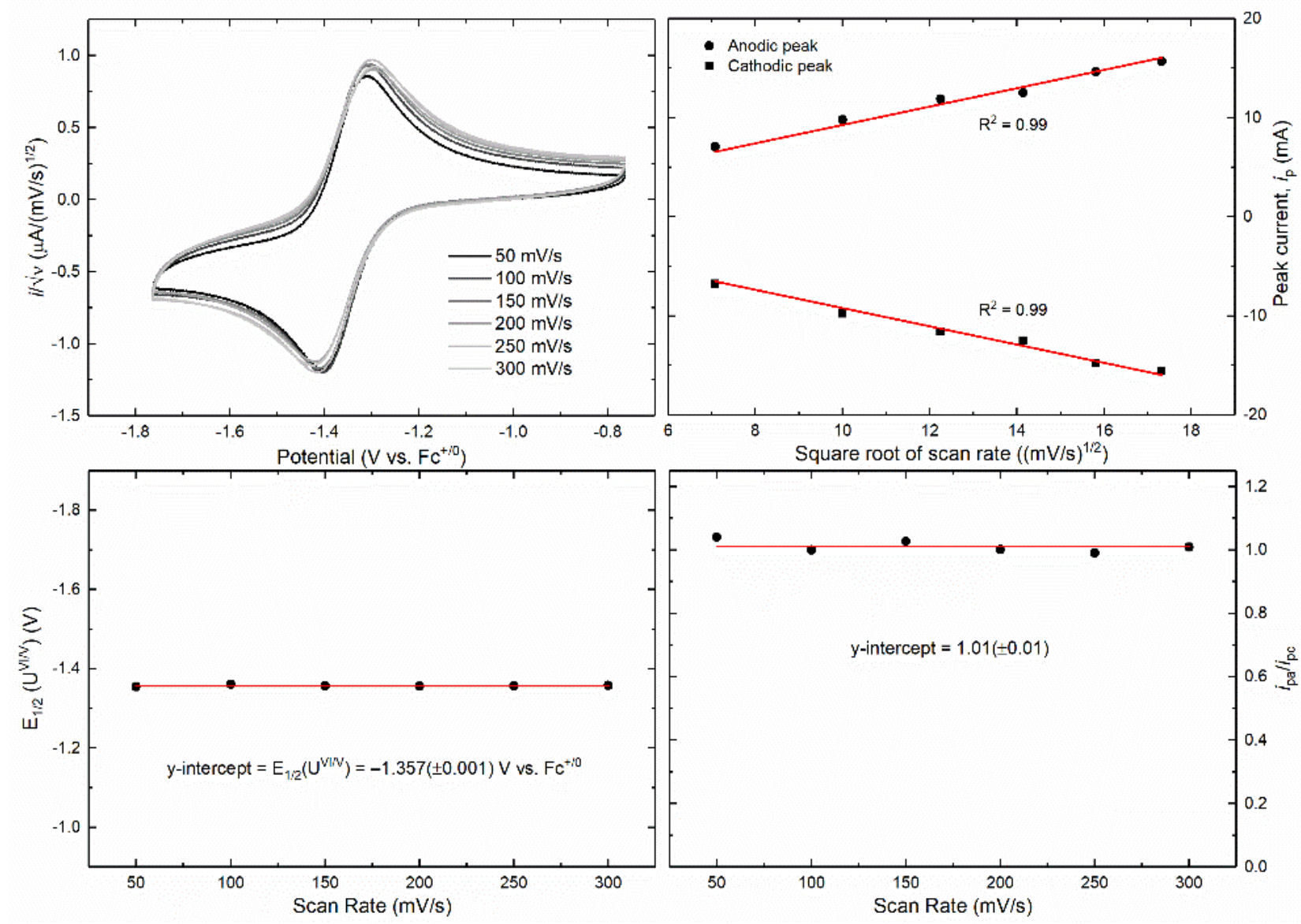

Figure S29. Analysis of electrochemical data confirming chemical reversibility of reduction of $\mathbf{L}^{\text {salben }} \mathbf{U O}_{2} \mathbf{K}$. The chemically reversible nature of electron transfer to this compound is confirmed $^{2}$ by the scan rate-independent $E_{1 / 2}$ value (lower left panel) as well as the scan rate-independent ratio of anodic to cathodic peak currents equal to $1.01( \pm 0.01)$ (lower right panel). This ratio indicates that electrochemically generated $\mathrm{U}^{\mathrm{V}}$ is recollected to regenerate the $\mathrm{U}^{\mathrm{VI}}$ starting complex with unity efficiency. These data were tabulated from background corrected current-voltage curves derived from a spline-fit procedure available in the literature ${ }^{3}$ which approximates the current-time (Cottrell-like) behavior of a diffusional process in cyclic voltammetry. ${ }^{4}$ These spline background-corrected data also effectively remove contributions from non-Faradaic currents at higher scan rate with the result that current-voltage curves normalized by the square root of scan rate overlap with high similarity (upper left panel). Consequently, the spline background-corrected anodic and cathodic peak currents tightly obey the expected dependence on the square root of scan rate required by the Randles-Ševčik equation for freely diffusing species (upper right panel). ${ }^{5,6}$ This tight agreement includes the expected $y$-intercept value of 0 within the error of the data $(1.39 \pm 0.58 ;-1.02 \pm 0.60)$. As the scan rate range accessible with our working electrodes $(A=$ $\left.0.09 \mathrm{~cm}^{2}\right)$ is not especially wide, the spline background-corrected data plotted to check agreement with the Randles-Ševčik equation do not differ greatly from their nonbackground-corrected counterparts (Figure S26). 


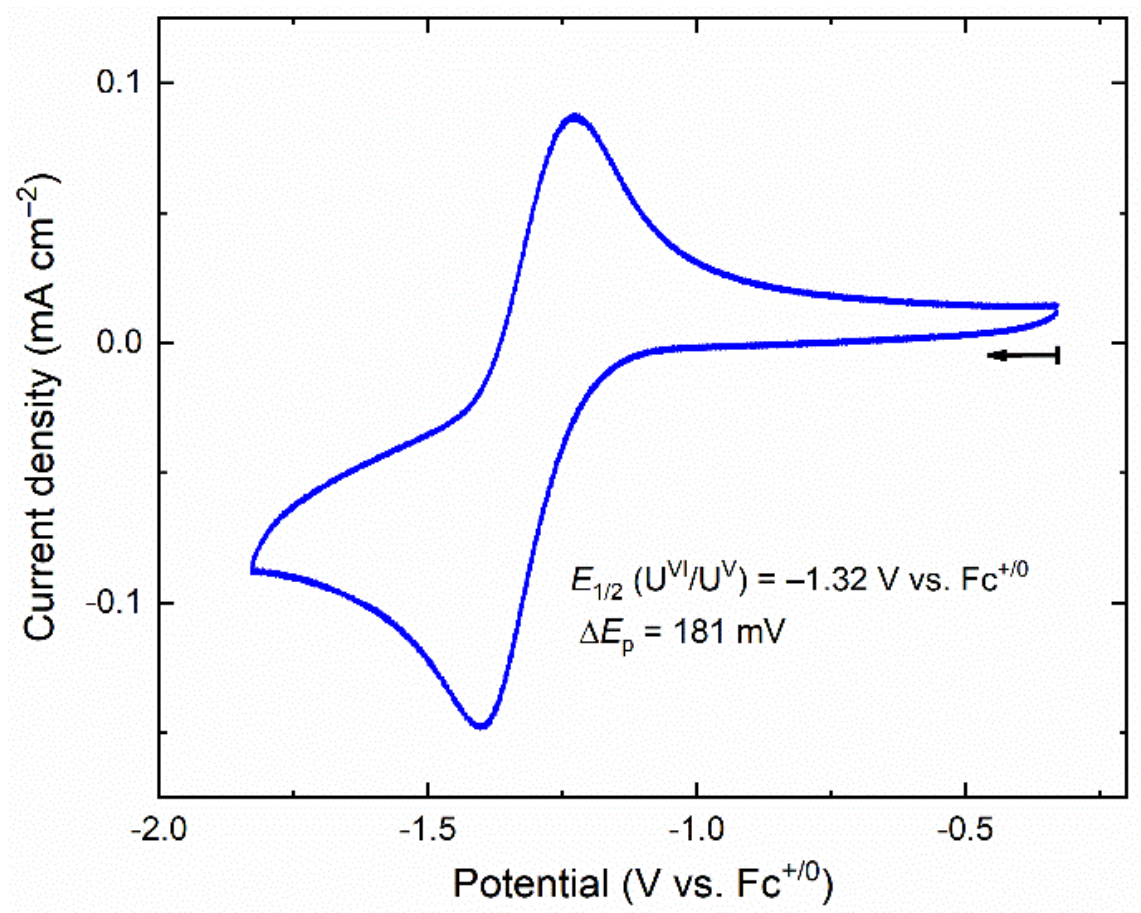

Figure S30. Cyclic voltammetry data for $\mathbf{L}^{\text {salben }} \mathbf{U O}_{2} \mathbf{N a}$ in $\mathrm{CH}_{3} \mathrm{CN}\left(0.1 \mathrm{M}\left[{ }^{\mathrm{n}} \mathrm{Bu}_{4} \mathrm{~N}\right]^{+}\left[\mathrm{PF}_{6}\right]^{-}\right.$, $100 \mathrm{mV} / \mathrm{s}$ ) showing the 'Early' scan.

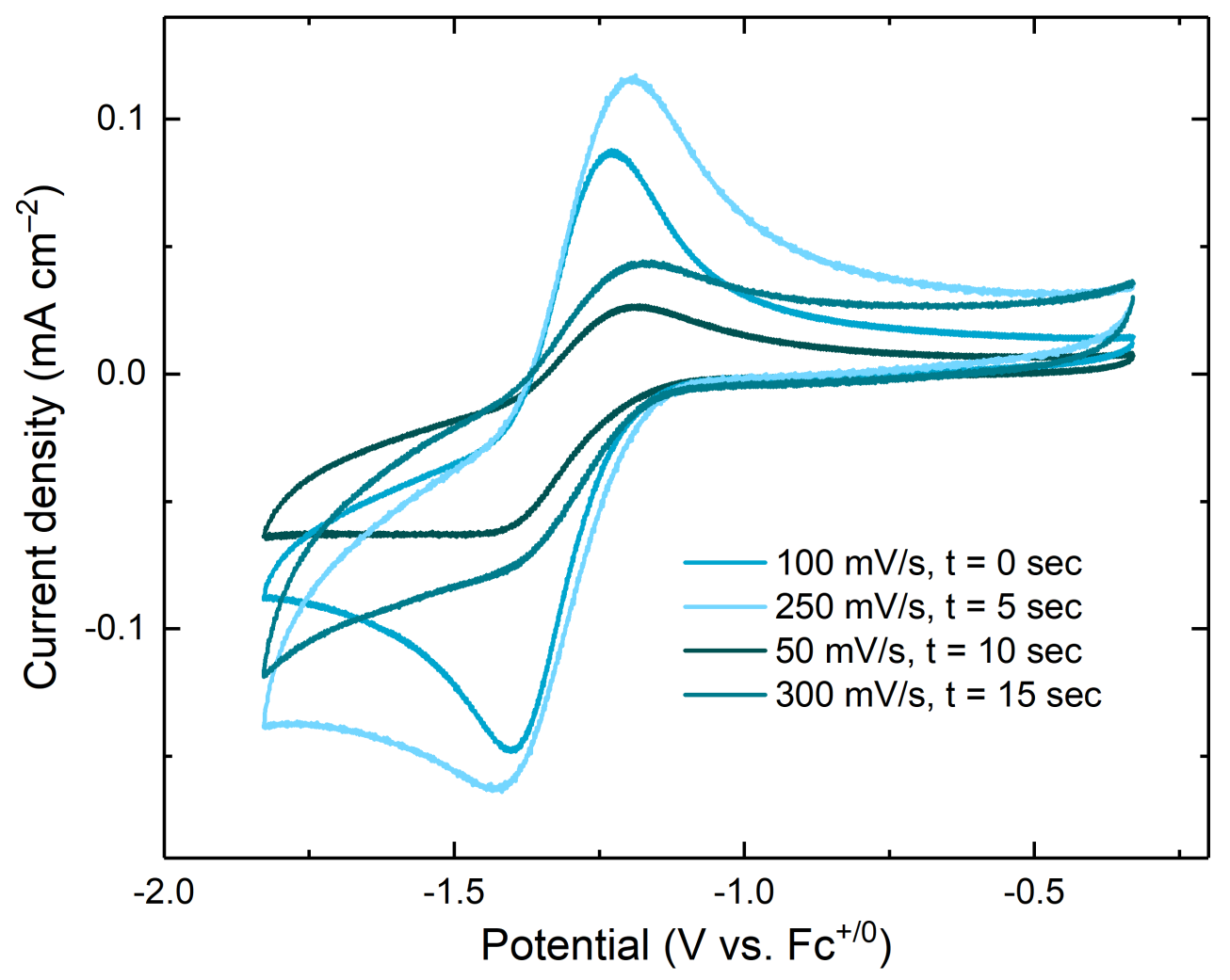

Figure S31. Scan rate dependence data for $\mathbf{L}^{\text {salben }} \mathbf{U O}_{2} \mathrm{Na}$ showing its decomposition after multiple scans spread over ca. 30 seconds. 


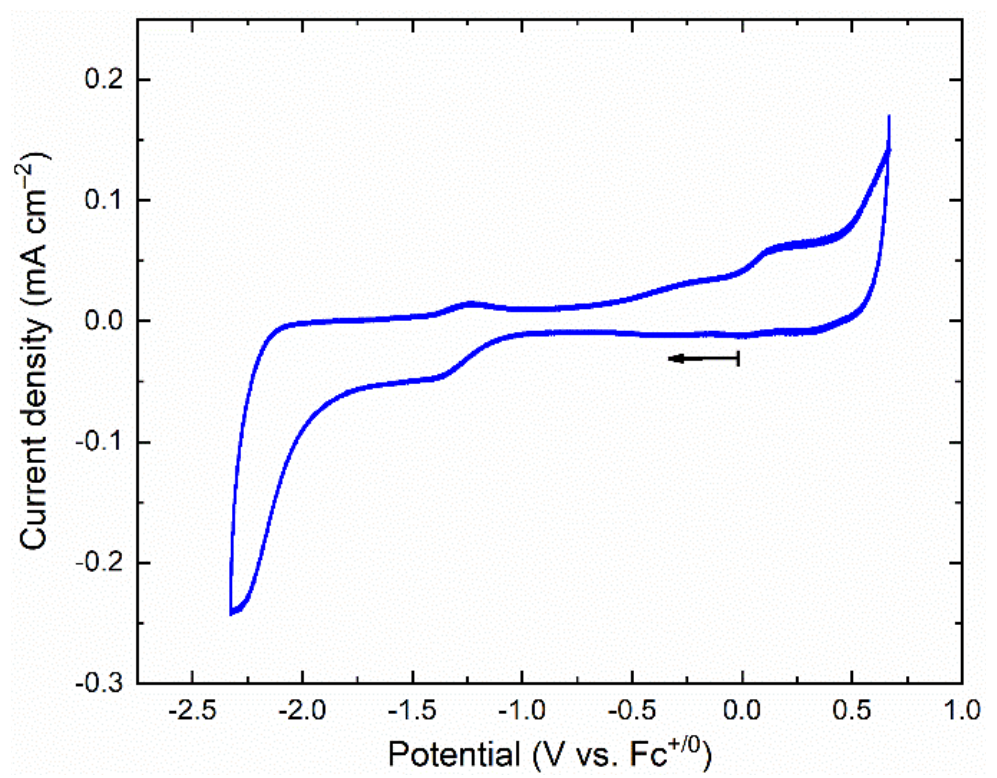

Figure S32. Cyclic voltammetry data for $\mathbf{L}^{\text {salben }} \mathbf{U O}_{2} \mathbf{N a}$ in $\mathrm{CH}_{3} \mathrm{CN}\left(0.1 \mathrm{M}\left[{ }^{\mathrm{n}} \mathrm{Bu} 4 \mathrm{~N}\right]^{+}\left[\mathrm{PF}_{6}\right]^{-}\right.$, $100 \mathrm{mV} / \mathrm{s}$ ) showing the 'Late Scan'. The CV shows decomposition of the complex after multiple scans (ca. 20 scans over 10 minutes).

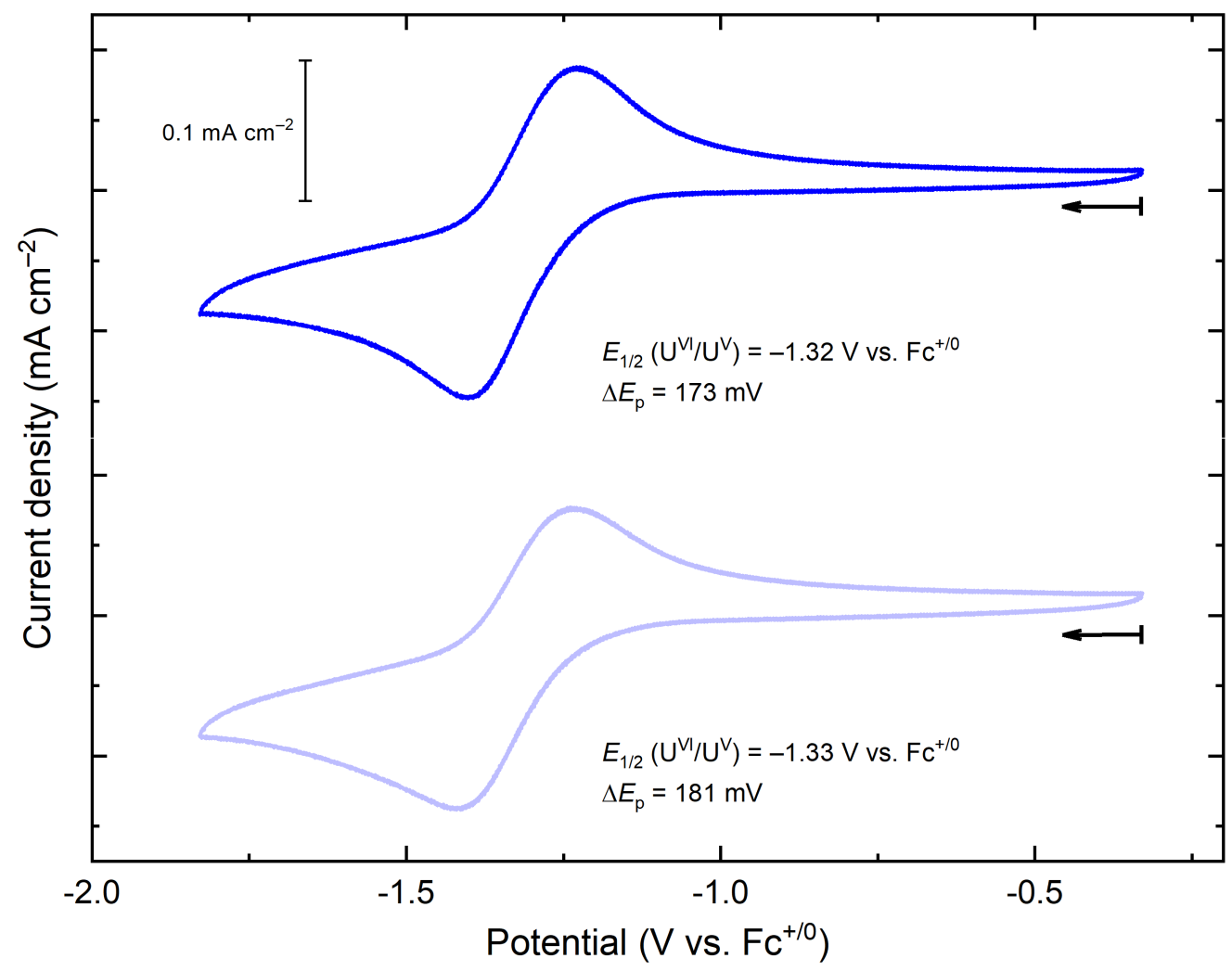

Figure S33. Cyclic voltammetry data for $\mathbf{L}^{\text {salben }} \mathbf{U O}_{2} \mathbf{N a}$ in $\mathrm{CH}_{3} \mathrm{CN}\left(0.1 \mathrm{M}\left[{ }^{\mathrm{n}} \mathrm{Bu}_{4} \mathrm{~N}\right]^{+}\left[\mathrm{PF}_{6}\right]^{-}\right.$, $100 \mathrm{mV} / \mathrm{s}$ ) using two different electrodes. 


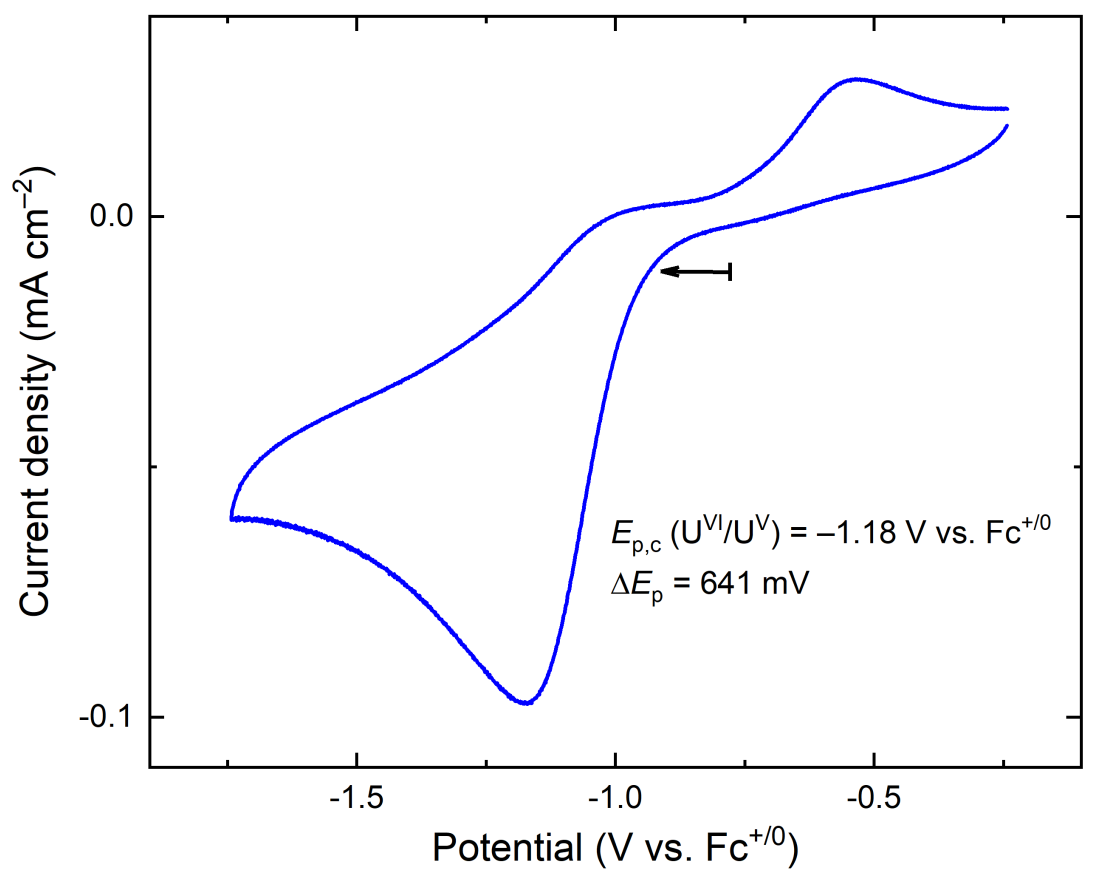

Figure S34. Cyclic voltammetry data for $\mathbf{L}^{\text {salben}} \mathbf{U O}_{2} \mathbf{C a}$ in $\mathrm{CH}_{3} \mathrm{CN}\left(0.1 \mathrm{M}\left[{ }^{\mathrm{n}} \mathrm{Bu} 4 \mathrm{~N}^{+}\left[\mathrm{PF}_{6}\right]^{-}\right.\right.$, $100 \mathrm{mV} / \mathrm{s}$ ) with a smaller potential window.

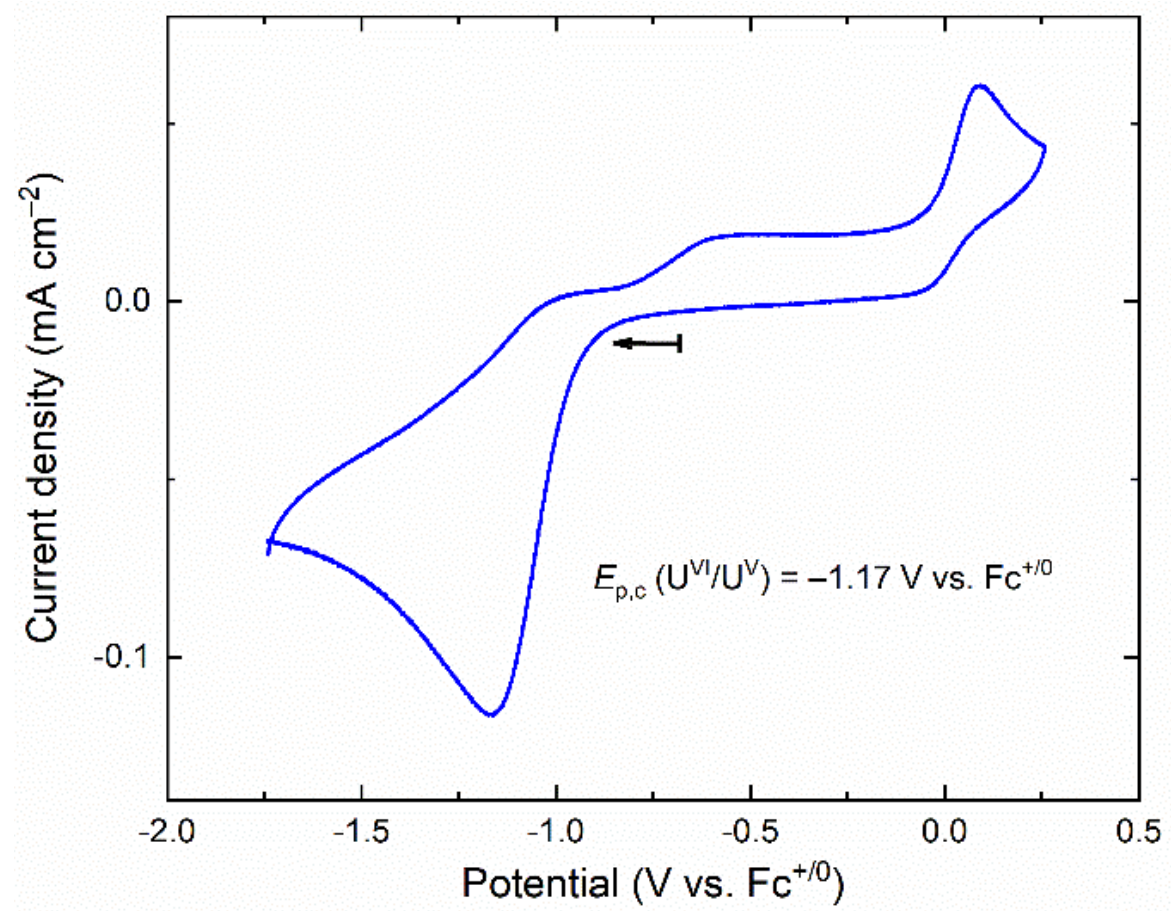

Figure S35. Cyclic voltammetry data for $\mathbf{L}^{\text {salben}} \mathbf{U} \mathbf{O}_{2} \mathbf{C a}$ in $\mathrm{CH}_{3} \mathrm{CN}\left(0.1 \mathrm{M}\left[{ }^{\mathrm{n}} \mathrm{Bu} 4 \mathrm{~N}^{+}\left[\mathrm{PF}_{6}\right]^{-}\right.\right.$, $100 \mathrm{mV} / \mathrm{s}$ ) with a larger potential window. 

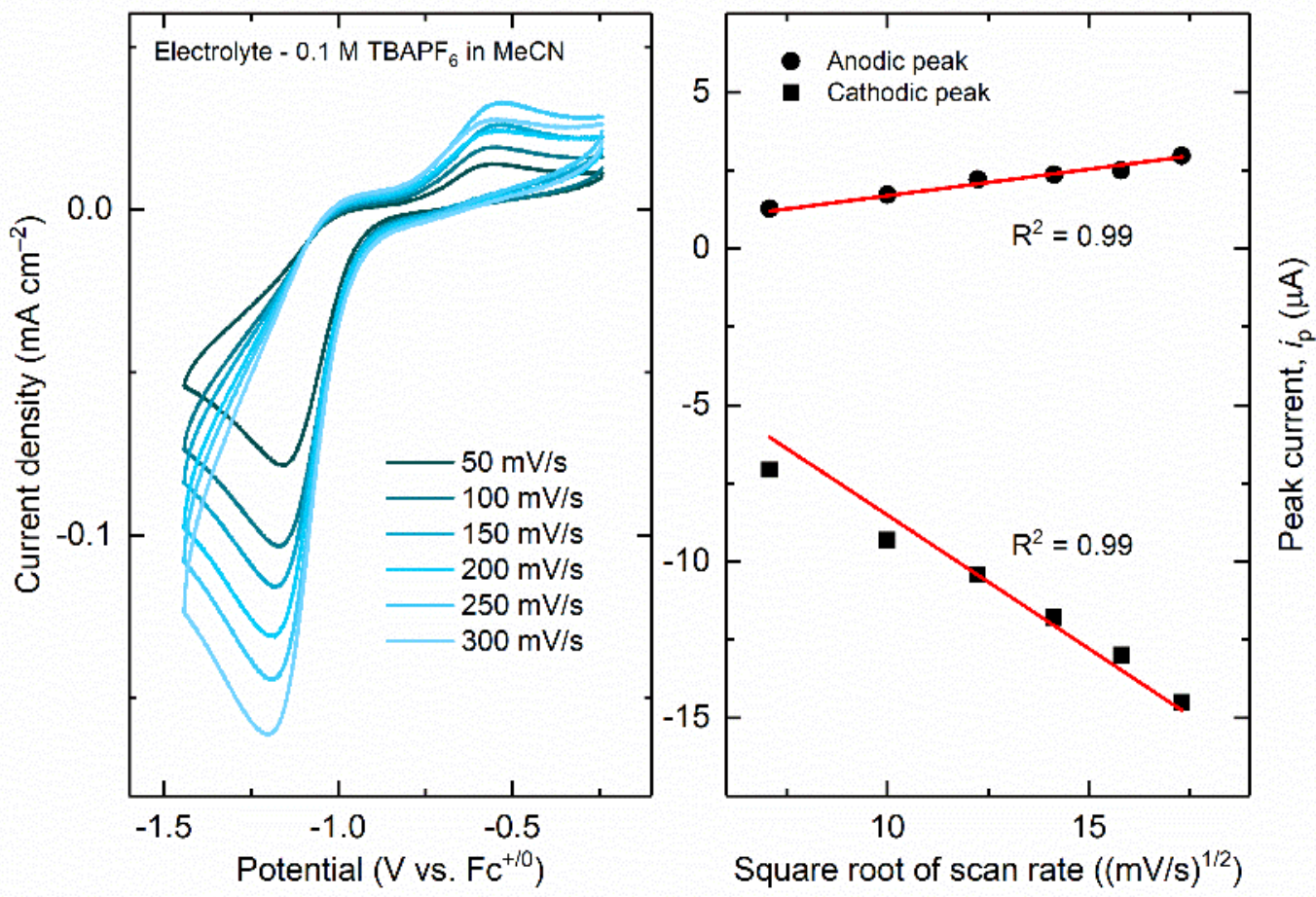

Figure S36. Left panel: scan rate dependence data for $\mathbf{L}^{\text {salben }} \mathbf{U} \mathbf{O}_{2} \mathbf{C a}$. Right panel: plot of peak current density vs. (scan rate) $)^{1 / 2}$, demonstrating the diffusional nature of the oxidized and reduced species involved in the redox couple in question. 


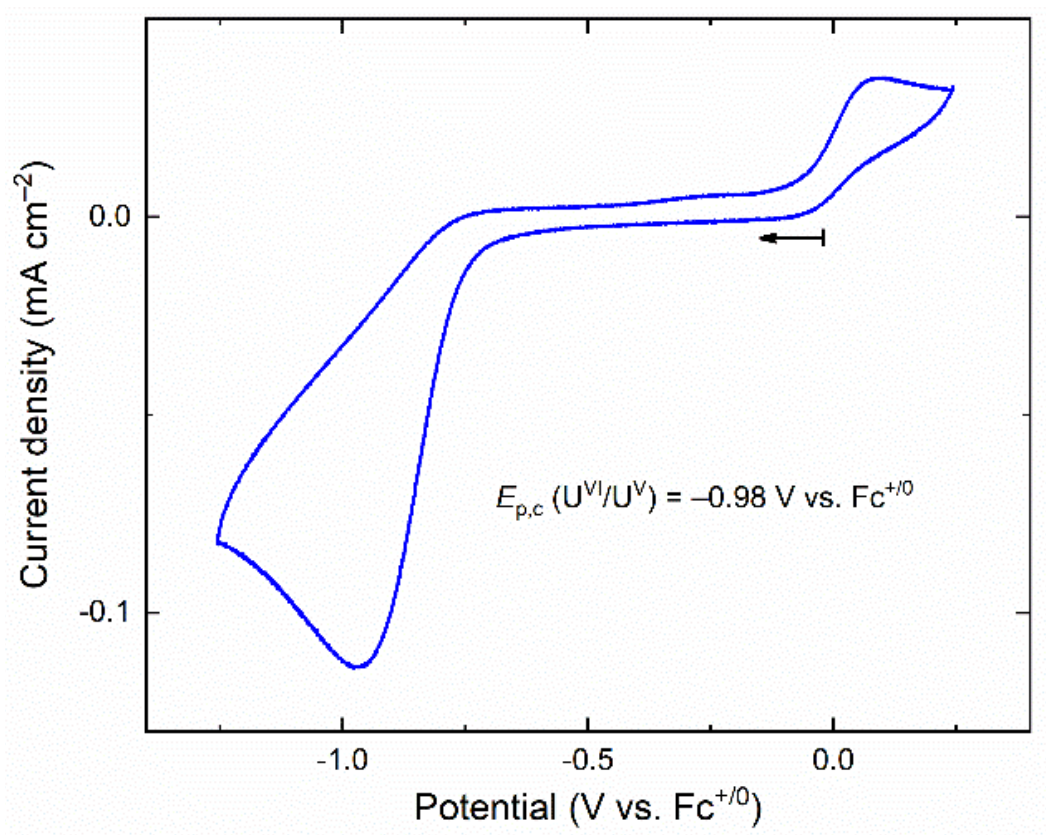

Figure S37. Cyclic voltammetry data for $\mathbf{L}^{\text {salben}} \mathbf{U O}_{2} \mathbf{N d}$ in $\mathrm{CH}_{3} \mathrm{CN}\left(0.1 \mathrm{M}\left[{ }^{\mathrm{n}} \mathrm{Bu}_{4} \mathrm{~N}\right]^{+}\left[\mathrm{PF}_{6}\right]^{-}\right.$, $100 \mathrm{mV} / \mathrm{s})$.
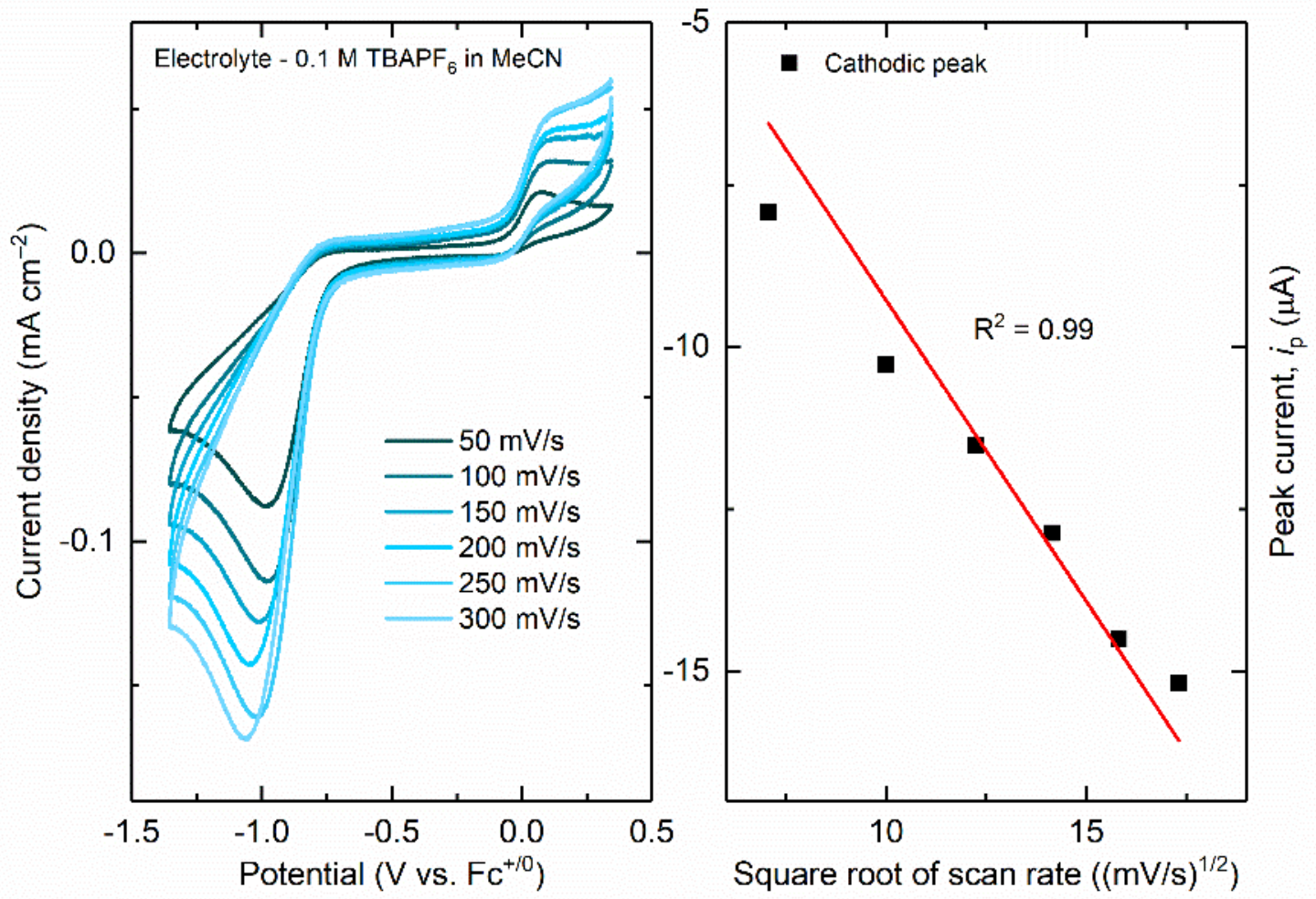

Figure S38. Left panel: scan rate dependence data for $\mathbf{L}^{\text {salben }} \mathbf{U} \mathbf{O}_{2} \mathbf{N d}$. Right panel: plot of peak current density vs. (scan rate) ${ }^{1 / 2}$, demonstrating the diffusional nature of the reduced species involved in the redox couple in question. 


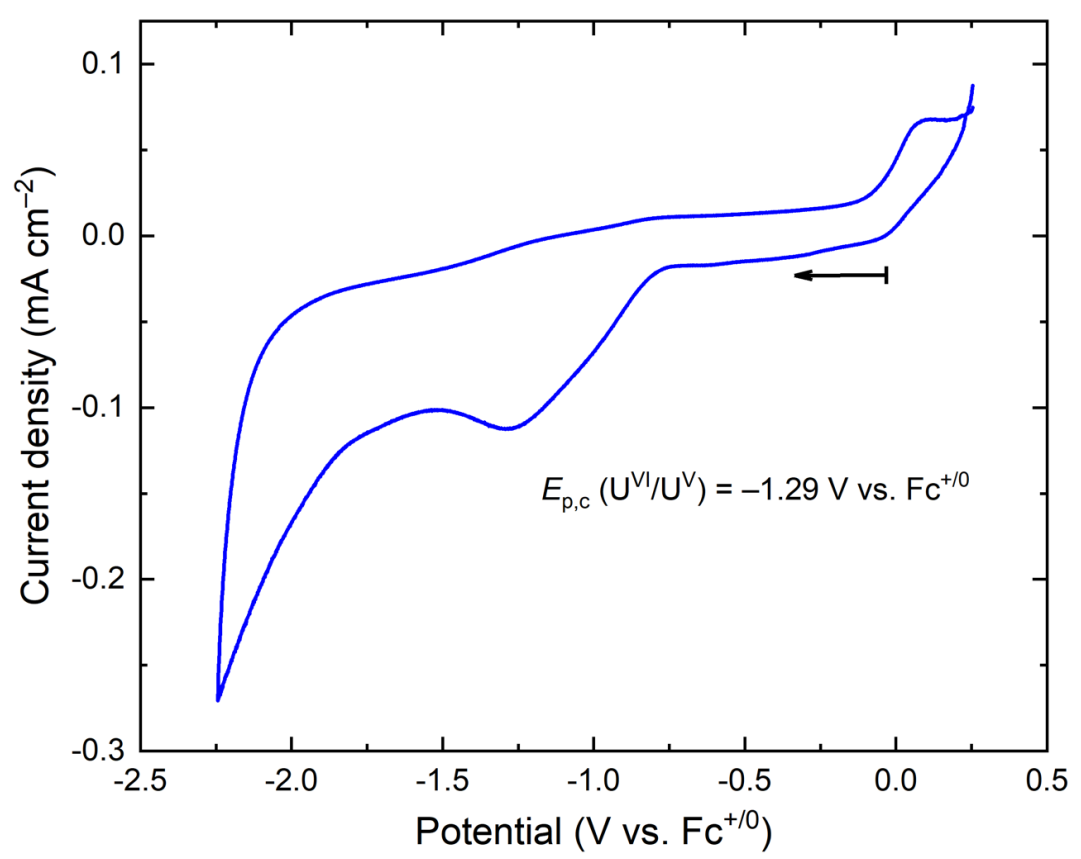

Figure S39. Cyclic voltammetry data for $\mathbf{L}^{\text {salben }} \mathbf{U O}_{2} \mathbf{Y}$ in $\mathrm{CH}_{3} \mathrm{CN}\left(0.1 \mathrm{M}\left[{ }^{\mathrm{n}} \mathrm{Bu}_{4} \mathrm{~N}\right]^{+}\left[\mathrm{PF}_{6}\right]^{-}, 100\right.$ $\mathrm{mV} / \mathrm{s})$.
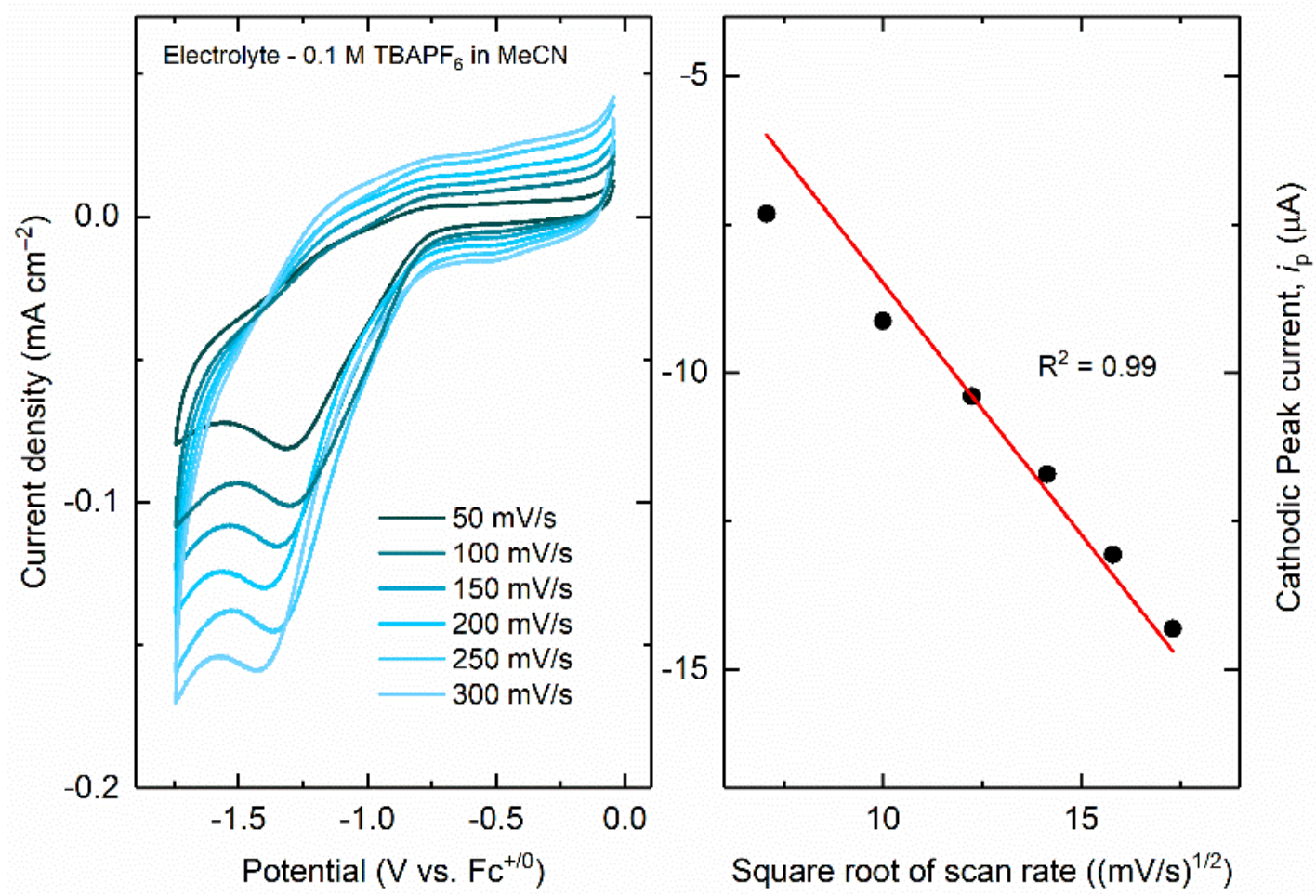

Figure S40. Left panel: scan rate dependence data for $\mathbf{L}^{\text {salben}} \mathbf{U} \mathbf{O}_{2} \mathbf{Y}$. Right panel: plot of peak current density vs. (scan rate) ${ }^{1 / 2}$, demonstrating the diffusional nature of the reduced species involved in the redox couple in question. 


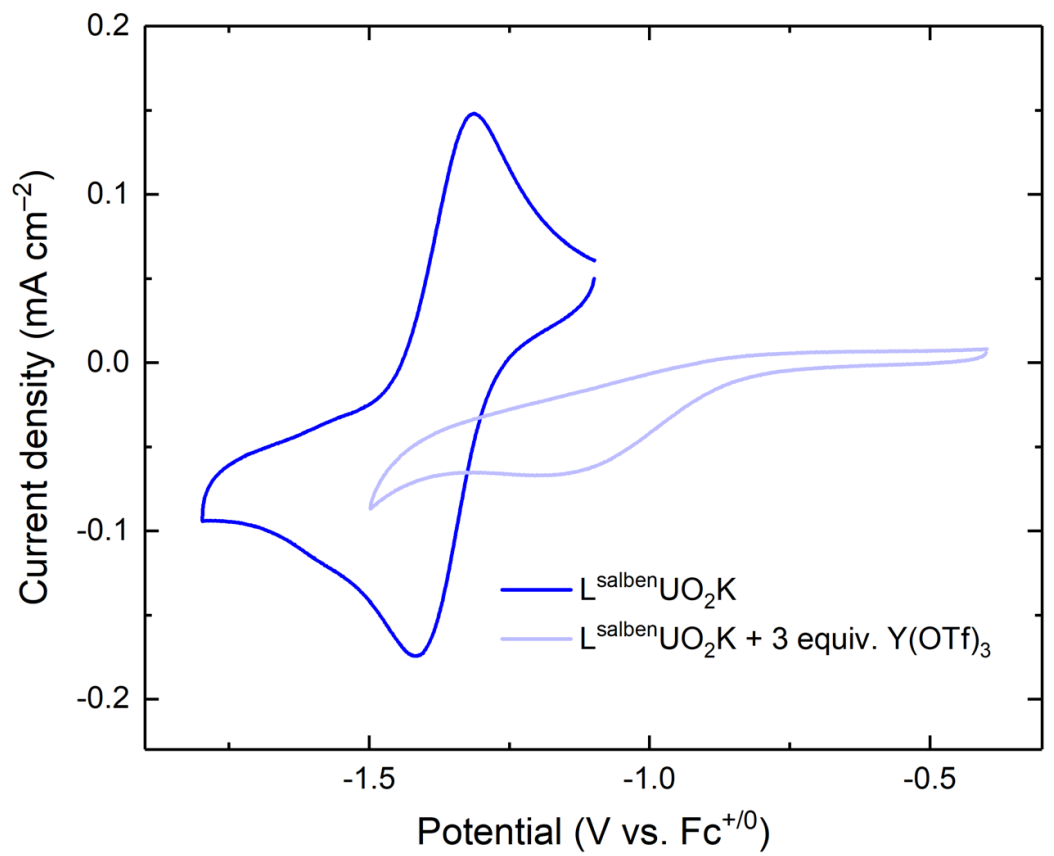

Figure S41. Plot showing variations in the cyclic voltammetry data of $\mathbf{L}^{\text {salben }} \mathbf{U} \mathbf{O}_{2} \mathbf{K}$ after addition of 3 equivalents of $\mathrm{Y}(\mathrm{OTf})_{3}$ to the working solution. Conditions: $\mathrm{CH}_{3} \mathrm{CN}(0.1 \mathrm{M}$ $\left.\left[{ }^{\mathrm{n}} \mathrm{Bu} 4 \mathrm{~N}\right]^{+}\left[\mathrm{PF}_{6}\right]^{-}, 100 \mathrm{mV} / \mathrm{s}\right)$.

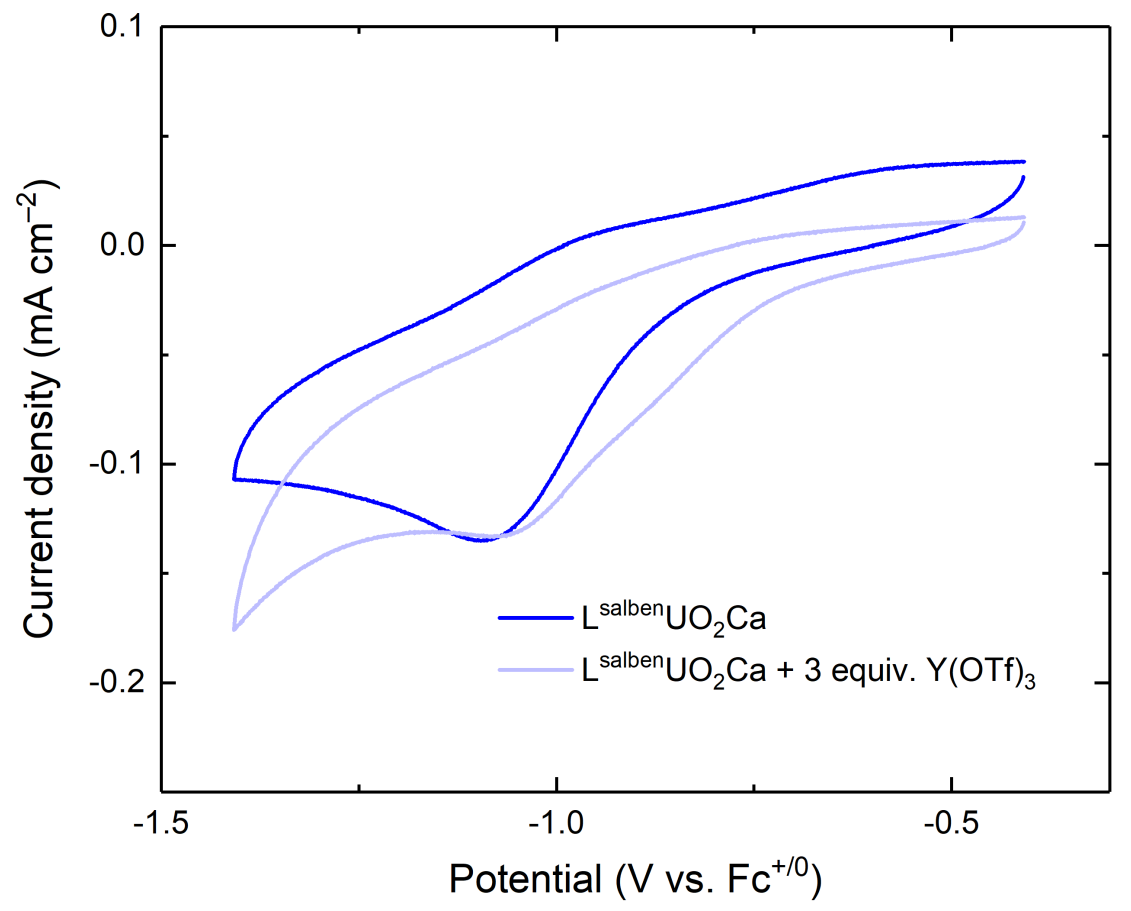

Figure S42. Plot showing small variations in the cyclic voltammetry data of $\mathbf{L}^{\text {salben }} \mathbf{U O}_{2} \mathbf{C a}$ after addition of 3 equivalents of $\mathrm{Y}(\mathrm{OTf})_{3}$ to the working solution. Conditions: $\mathrm{CH}_{3} \mathrm{CN}(0.1$ $\left.\mathrm{M}\left[{ }^{\mathrm{n}} \mathrm{Bu} 4 \mathrm{~N}\right]^{+}\left[\mathrm{PF}_{6}\right]^{-}, 100 \mathrm{mV} / \mathrm{s}\right)$. 


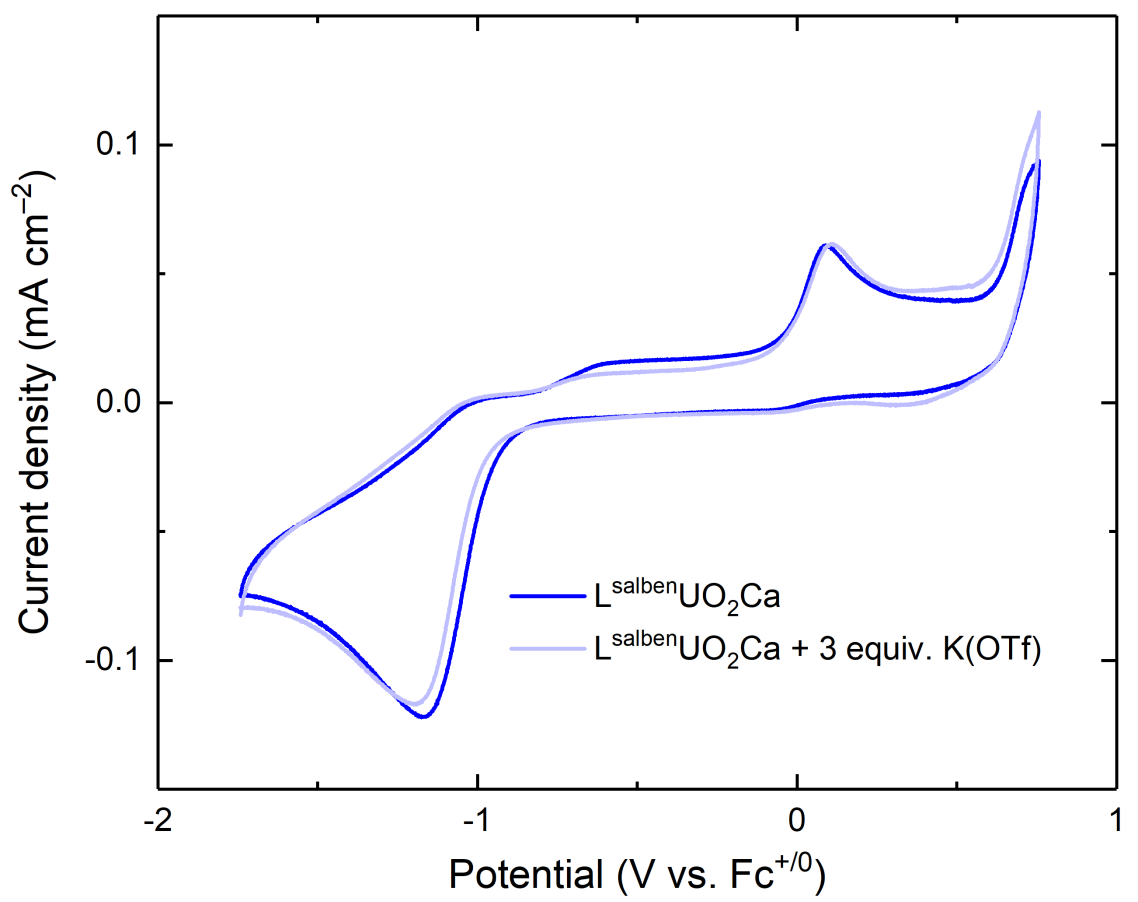

Figure S43. Plot showing negligible change in the cyclic voltammetry data of $\mathbf{L}^{\text {salben }} \mathbf{U O}_{2} \mathbf{C a}$ after addition of 3 equivalents of $\mathrm{K}(\mathrm{OTf})$ to the working solution. Conditions: $\mathrm{CH}_{3} \mathrm{CN}(0.1$ $\left.\mathrm{M}\left[{ }^{\mathrm{n}} \mathrm{Bu}_{4} \mathrm{~N}\right]^{+}\left[\mathrm{PF}_{6}\right]^{-}, 100 \mathrm{mV} / \mathrm{s}\right)$. 


\section{Spectroelectrochemistry}

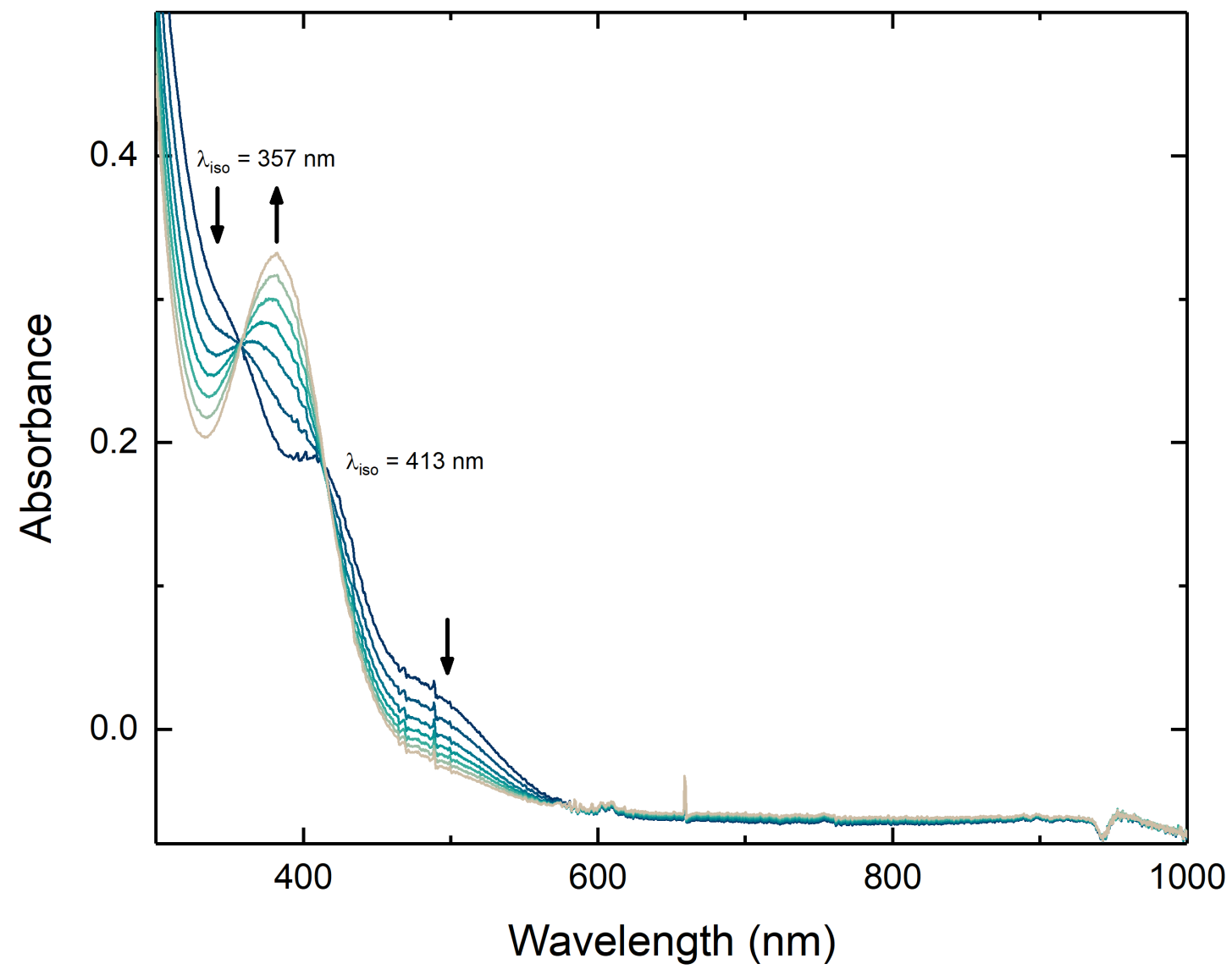

Figure S44. Spectroelectrochemical data for the electrolysis of $\mathbf{L}^{\text {salben }} \mathbf{U}^{\mathbf{V I}} \mathbf{O}_{2}$ over a period of 5 minutes. Step potential for generation of $\mathbf{L}^{\text {salben }} \mathbf{U}^{\mathbf{V}} \mathbf{O}_{2}$ was $-1.2 \mathrm{~V}$ vs. reference. Electrolyte: $0.1 \mathrm{M}\left[{ }^{\mathrm{n}} \mathrm{Bu}_{4} \mathrm{~N}\right]^{+}\left[\mathrm{PF}_{6}\right]^{-}$in DMF. 


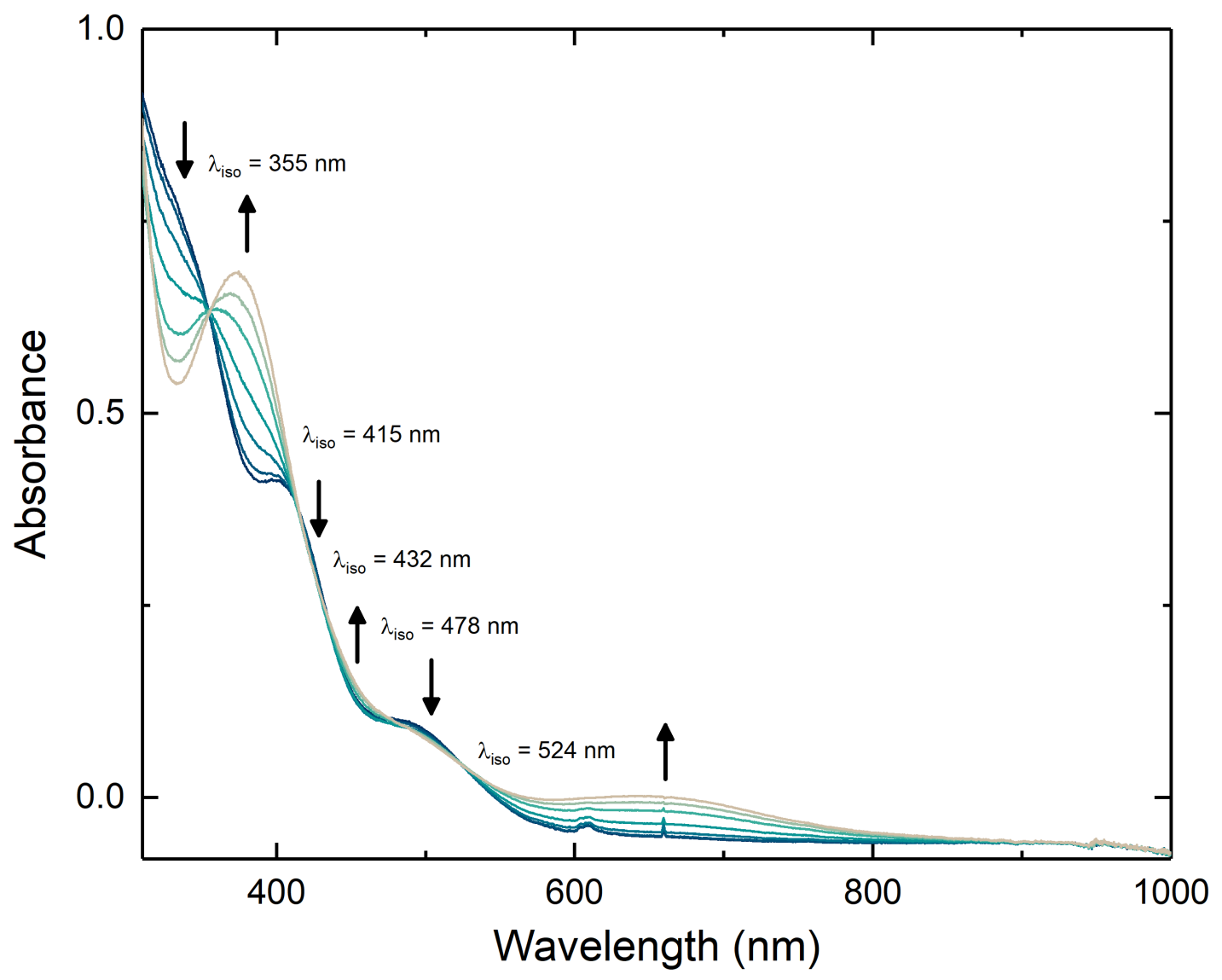

Figure S45. Spectroelectrochemical data for the electrolysis of $\mathbf{L}^{\text {salben }} \mathbf{U}^{\mathrm{VI}} \mathbf{O}_{2} \mathbf{K}$ over a period of 6 minutes. Step potential for generation of $\mathbf{L}^{\text {salben }} \mathbf{U}^{\mathbf{V}} \mathbf{O}_{2} \mathbf{K}$ was $-3.0 \mathrm{~V}$ vs. reference. Electrolyte: $0.1 \mathrm{M}\left[{ }^{\mathrm{n}} \mathrm{Bu}_{4} \mathrm{~N}\right]^{+}\left[\mathrm{PF}_{6}\right]^{-}$in $\mathrm{CH}_{3} \mathrm{CN}$. 


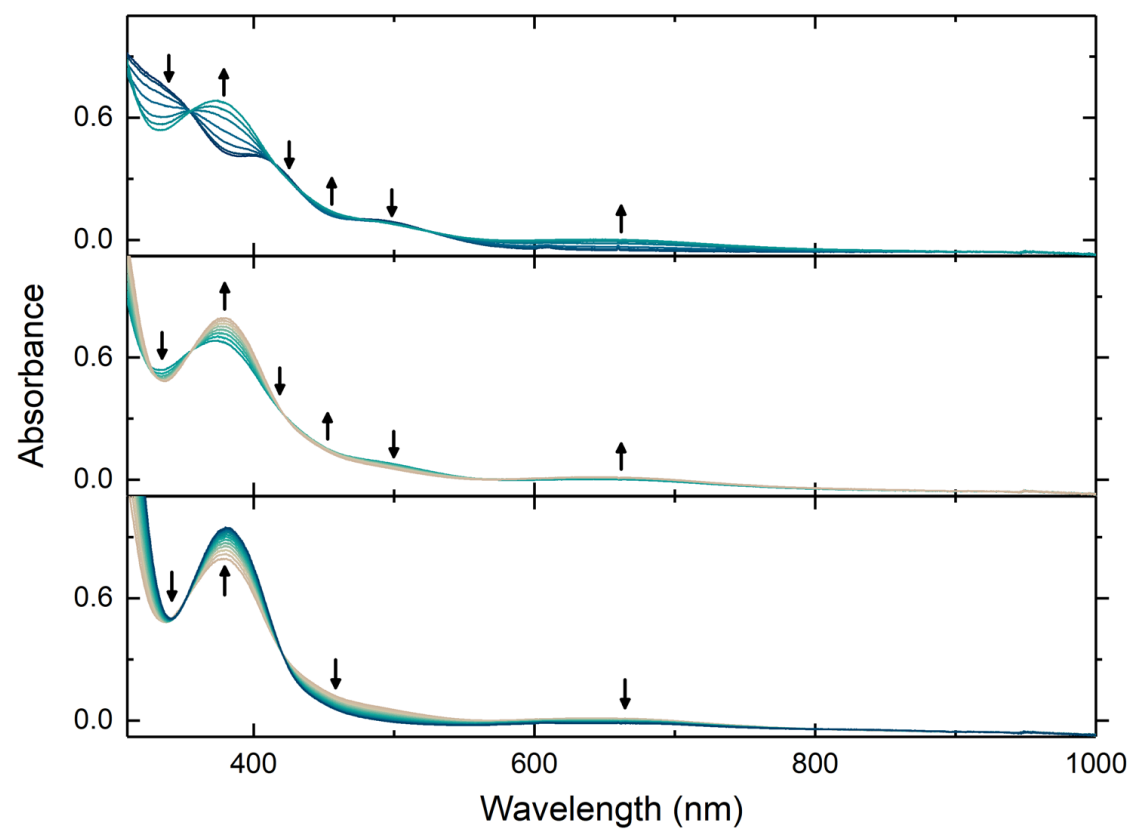

Figure S46. Stacked spectroelectrochemical data (full region) for the electrolysis of $\mathbf{L}^{\text {salben }} \mathbf{U}^{\mathrm{VI}} \mathbf{O}_{2} \mathbf{K}$ showing changes over a period of 23 minutes. Top: $t=0$ min to $t=6 \mathrm{~min}$; Middle: $\mathrm{t}=6 \mathrm{~min}$ to $\mathrm{t}=10 \mathrm{~min}$; Bottom: $\mathrm{t}=6 \mathrm{~min}$ to $\mathrm{t}=23 \mathrm{~min}$. Step potential for generation of $\mathbf{L}^{\text {salben }} \mathbf{U}^{\mathrm{V}} \mathbf{O}_{2} \mathbf{K}$ was $-3.0 \mathrm{~V}$ vs. reference. Electrolyte: $0.1 \mathrm{M}\left[{ }^{\mathrm{n}} \mathrm{Bu}_{4} \mathrm{~N}^{+}\left[\mathrm{PF}_{6}\right]^{-}\right.$in $\mathrm{CH}_{3} \mathrm{CN}$.

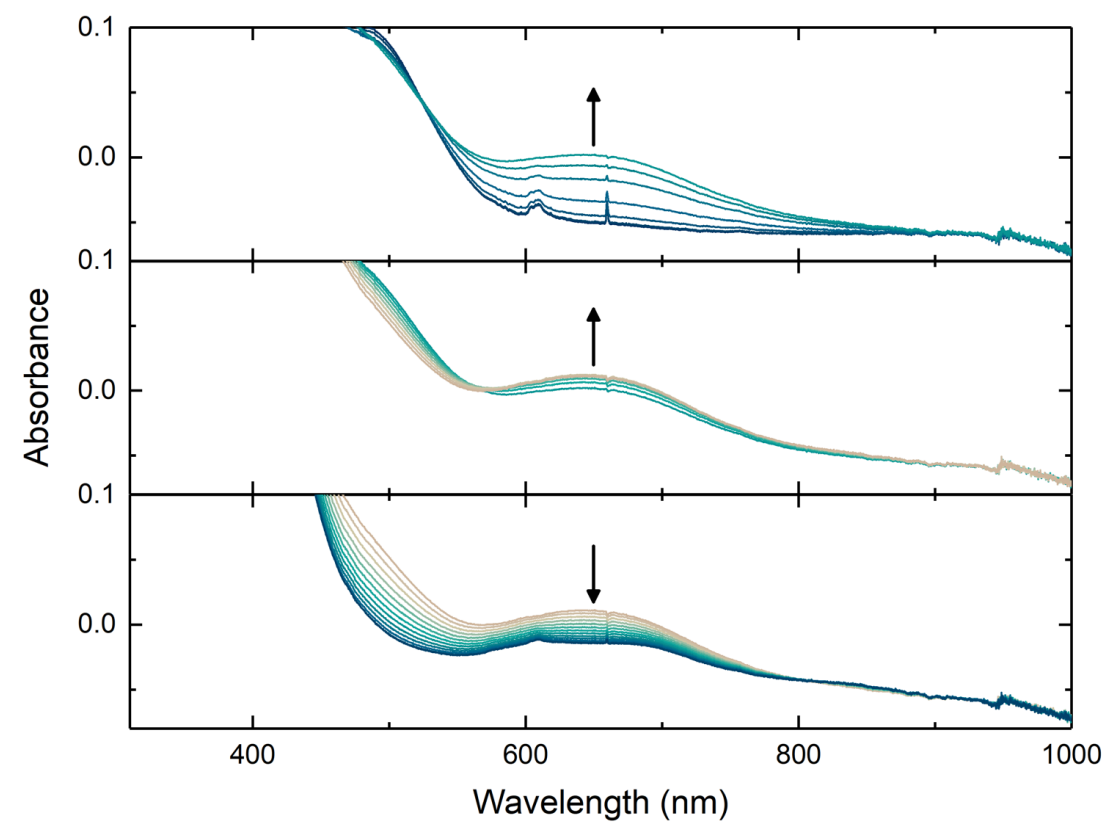

Figure S47. Stacked spectroelectrochemical data (small region) for the electrolysis of $\mathbf{L}^{\text {salben }} \mathbf{U}^{\mathrm{VI}} \mathbf{O}_{2} \mathbf{K}$ showing changes over a period of 23 minutes. Top: $t=0$ min to $t=6$ min; Middle: $\mathrm{t}=6 \mathrm{~min}$ to $\mathrm{t}=10 \mathrm{~min}$; Bottom: $\mathrm{t}=6 \mathrm{~min}$ to $\mathrm{t}=23 \mathrm{~min}$. Step potential for generation of $\mathbf{L}^{\text {salben }} \mathbf{U}^{\mathrm{V}} \mathbf{O}_{2} \mathbf{K}$ was $-3.0 \mathrm{~V}$ vs. reference. Electrolyte: $0.1 \mathrm{M}\left[{ }^{\mathrm{n}} \mathrm{Bu}_{4} \mathrm{~N}\right]^{+}\left[\mathrm{PF}_{6}\right]^{-}$in $\mathrm{CH}_{3} \mathrm{CN}$. 


\section{X-Ray Crystallography}

All crystals were mounted in Paratone oil on MiTeGen MicroMounts and complete sets of low temperature $(200 \mathrm{~K})$ diffraction data frames were collected using $1^{\circ}$-wide $\omega$ - or $\varphi$-scans with a dual CCD detector Bruker Proteum X-ray diffractometer. X-rays were provided by a Bruker MicroStar microfocus rotating anode generator running at $45 \mathrm{~mA}$ and $60 \mathrm{kV}\left(\mathrm{Cu} \mathrm{K}_{\alpha}\right.$ $=1.54178 \AA$ ). Data for $\mathbf{L}^{\text {salben }} \mathbf{U} \mathbf{O}_{2} \mathbf{N a}$ and $\mathbf{L}^{\text {salben }} \mathbf{U} \mathbf{O}_{2} \mathbf{Y}$ were collected with a Bruker APEX II CCD detector positioned at $50.0 \mathrm{~mm}$ and equipped with Helios multilayer mirror optics; data for $\mathbf{L}^{\text {salben }} \mathrm{H}_{2} \mathbf{B a}, \mathbf{L}^{\text {salben }} \mathbf{U O}_{2}, \mathbf{L}^{\text {salben }} \mathbf{U O}_{2} \mathbf{K}$ and $\mathbf{L}^{\text {salben }} \mathbf{U O}_{2} \mathrm{Ca}$ were collected with a Bruker Platinum $135 \mathrm{CCD}$ detector positioned at $80.0 \mathrm{~mm}$ and equipped with Helios highbrilliance multilayer mirror optics. All diffractometer manipulations, including data collection, integration and scaling were carried out using the Bruker APEX2 software. Absorption corrections were applied using SADABS. ${ }^{8}$ Probable space groups were determined on the basis of systematic absences and the structures were solved by direct methods using SIR $2004^{9}$ or $\mathrm{XS}^{10}$ (incorporated into SHELXTL) and refined to convergence by weighted full-matrix least squares on $\mathrm{F}^{2}$ using the Olex2 software package equipped with XL. ${ }^{11}$

All non-hydrogen atoms were refined using anisotropic displacement parameters. Hydrogen atoms for all structures except $\mathbf{L}^{\text {salben }} \mathbf{H}_{2} \mathbf{B a}$ were placed at idealized positions and refined using a riding model. Rigid body methyl groups with $\mathrm{sp}^{3}$-hybridized carbons and $\mathrm{C}-\mathrm{H}$ bond lengths of $0.98 \AA$ were placed either at idealized "staggered" positions or they were allowed to rotate freely about their $\mathrm{O}-\mathrm{C}, \mathrm{N}-\mathrm{C}$ or $\mathrm{C}-\mathrm{C}$ bonds in least-squares refinement cycles. Hydrogen atoms for $\mathbf{L}^{\text {salben}} \mathbf{H}_{2} \mathbf{B a}$ were located in a difference Fourier map and refined as independent isotropic atoms in least-squares refinement cycles.

The relevant crystallographic and structure refinement data for all six compounds are given in Tables S1, S2 and S3.

The location and refinement of all hydrogen atoms in $\mathbf{L}^{\text {salben }} \mathbf{H}_{2}$ Ba permits the unambiguous identification of two intramolecular $\mathrm{N}-\mathrm{H} \cdots \mathrm{O}$ hydrogen bonds which provide additional rigidity to one end of the macrocycle. The uranyl group occupies this end of the macrocycle in the other five structures.

The $\mathrm{U}=\mathrm{O}$ bond lengths in $\mathbf{L}^{\text {salben }} \mathbf{U O}_{2}, \mathbf{L}^{\text {salben }} \mathbf{U O}_{2} \mathbf{K}, \mathbf{L}^{\text {salben }} \mathbf{U O}_{2} \mathbf{N a}, \mathbf{L}^{\text {salben }} \mathbf{U O}_{2} \mathrm{Ca}$ and $\mathbf{L}^{\text {salben }} \mathbf{U O}_{2} \mathbf{Y}$ range from $1.771(6) \AA$ to $1.795(4) \AA$. The linear uranyl group is within $1.4^{\circ}$ of being perpendicular to the mean planes for each of the $\mathrm{U}, \mathrm{O} 1, \mathrm{O} 2, \mathrm{~N} 1, \mathrm{~N} 2$ and $\mathrm{N} 3$ groupings. Each of these 6-atom groupings are nearly coplanar with a narrow range of rms (root-mean-square) deviations from their respective mean planes (the parameter defined in this report as $\left.\omega_{\text {crown }}\right)$ ranging from 0.038 to $0.160 \AA$. Maximum deviations of individual atoms from these 6-atom mean planes range from $0.070 \AA$ to $0.272 \AA$. Each of the 9-atom (N1, O6, C1, C2, C3, C4, C5, C6 and C7; N2, O3, C14, C15, C16, C17, C18, C19 and C20) groupings are also nearly coplanar with rms deviations from their respective 9-atom mean planes $\left(\omega_{\text {iminophenoxide }}\right.$ values) ranging from $0.010 \AA$ to $0.090 \AA$. Maximum deviations of individual atoms from the 9-atom mean plane range from $0.022 \AA$ to $0.206 \AA$. The six macrocyclic oxygen donors of the crown-ether-like moiety are significantly less coplanar 
with a broader range of rms deviations from their respective 6 -atom mean planes $\left(\omega_{\text {crown }}\right)$ ranging from $0.214 \AA$ to $0.642 \AA$. The metals binding to these oxygens have coordination numbers ranging from seven to ten: $\mathrm{Na}^{+}$and $\mathrm{K}^{+}, 7 ; \mathrm{Ca}^{2+}$ and $\mathrm{Y}^{3+}, 9$; and $\mathrm{Ba}^{2+}, 10$. $\mathbf{L}^{\text {salben }} \mathbf{U O}_{2} \mathbf{K}, \mathbf{L}^{\text {salben }} \mathbf{U O}_{2} \mathrm{Na}$ and $\mathbf{L}^{\text {salben }} \mathbf{U O}_{2} \mathrm{Ca}$ all have a single $\kappa^{1}$-coordinated triflate also bound to the second metal. The $\mathrm{Ca}^{2+}$ in $\mathbf{L}^{\text {salben}} \mathbf{U} \mathbf{O}_{2} \mathbf{C a}$ also has two coordinated methanol ligands. The $\mathrm{Y}^{3+}$ in $\mathbf{L}^{\text {salben}} \mathbf{U} \mathbf{O}_{2} \mathbf{Y}$ has two $\kappa^{1}$-coordinated triflates and a coordinated acetonitrile while the $\mathrm{Ba}^{2+}$ in $\mathbf{L}^{\text {salben }} \mathbf{H}_{2} \mathbf{B a}$ has two $\kappa^{2}$-coordinated triflates.

Although $\mathbf{L}^{\text {salben }} \mathbf{U O}_{2} \mathbf{K}$ and $\mathbf{L}^{\text {salben }} \mathbf{U O}_{2} \mathbf{N a}$ are isomorphous and the 7-coordinate ionic radius for $\mathrm{Na}^{+}$is $0.34 \AA$ less than the 7 -coordinate ionic radius for $\mathrm{K}^{+}$, the average $\mathrm{Na}-\mathrm{O}$ bond lengths are only $0.02 \AA$ shorter than the average $\mathrm{K}-\mathrm{O}$ bond lengths. Nonetheless, the $\mathrm{M}-\mathrm{O}$ bond lengths for this series of compounds generally follow a trend based on the respective ionic radii of $\mathrm{M}$; thus, those for $\mathrm{Y}^{3+}$ are the shortest as it has the smallest ionic radius. As a result, the $\mathrm{O} \bullet \bullet \mathrm{O}$ and $\mathrm{O} \bullet \bullet \mathrm{N}$ contacts on the $\mathrm{Y}^{3+}$ coordination sphere are the shortest for this series and are essentially at, or slightly below, the sum of the respective van der Waals radii.

The $\mathrm{O} 1 \cdots \mathrm{O} 2$ separation (the separation between the phenoxide donor $\mathrm{O}$ atoms) changes dramatically through this series with values of $3.64 \AA, 3.14 \AA, 2.99 \AA, 2.97 \AA, 2.95 \AA$ and $2.78 \AA$ for $\mathbf{L}^{\text {salben }} \mathrm{H}_{2} \mathbf{B a}, \quad \mathbf{L}^{\text {salben }} \mathbf{U O}_{2}, \quad \mathbf{L}^{\text {salben }} \mathbf{U O}_{2} \mathbf{K}, \quad \mathbf{L}^{\text {salben }} \mathbf{U O}_{2} \mathbf{N a}, \quad \mathbf{L}^{\text {salben}} \mathbf{U O}_{2} \mathrm{Ca}$ and $\mathbf{L}^{\text {salben }} \mathrm{UO}_{2} \mathbf{Y}$, respectively. 


\section{Special Refinement Details for $\mathrm{L}^{\text {salben }} \mathrm{H}_{2} \mathrm{Ba}$.}

No special refinement was required. Both triflate counteranions are bound in a $\kappa^{2}$ fashion to the formally 10 -coordinate $\mathrm{Ba}^{2+}$.

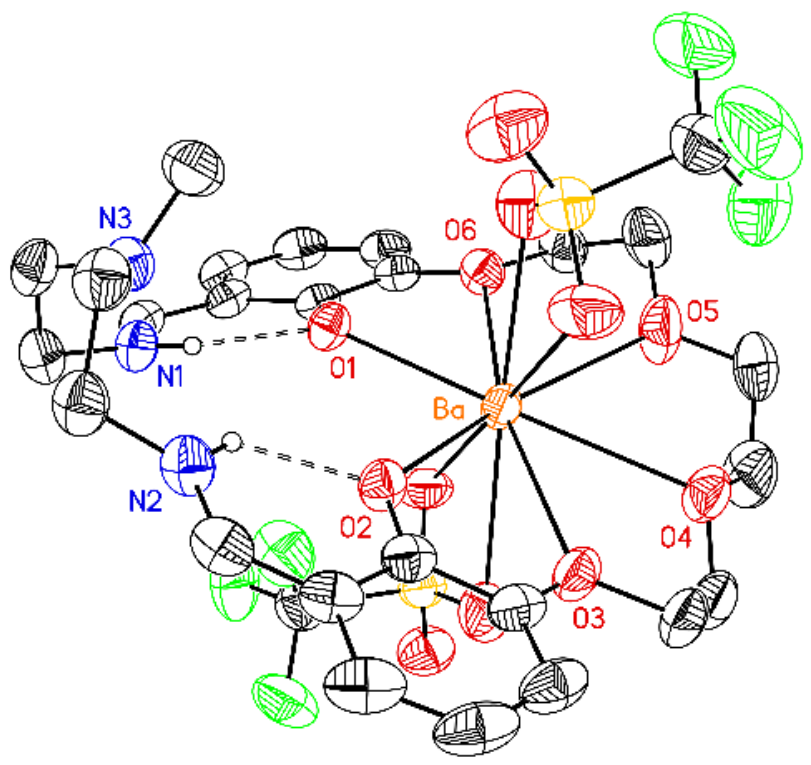

Figure S48. Solid-state structure (from XRD) of $\mathbf{L}^{\text {salben }} \mathbf{H}_{2} \mathbf{B a}$. H-atoms except those covalently bonded to $\mathrm{N} 1$ and $\mathrm{N} 2$ and involved in intramolecular $\mathrm{N}-\mathrm{H} \cdots \mathrm{O} \mathrm{H}$-bonds are omitted for clarity. Displacement ellipsoids are shown at the $50 \%$ probability level.

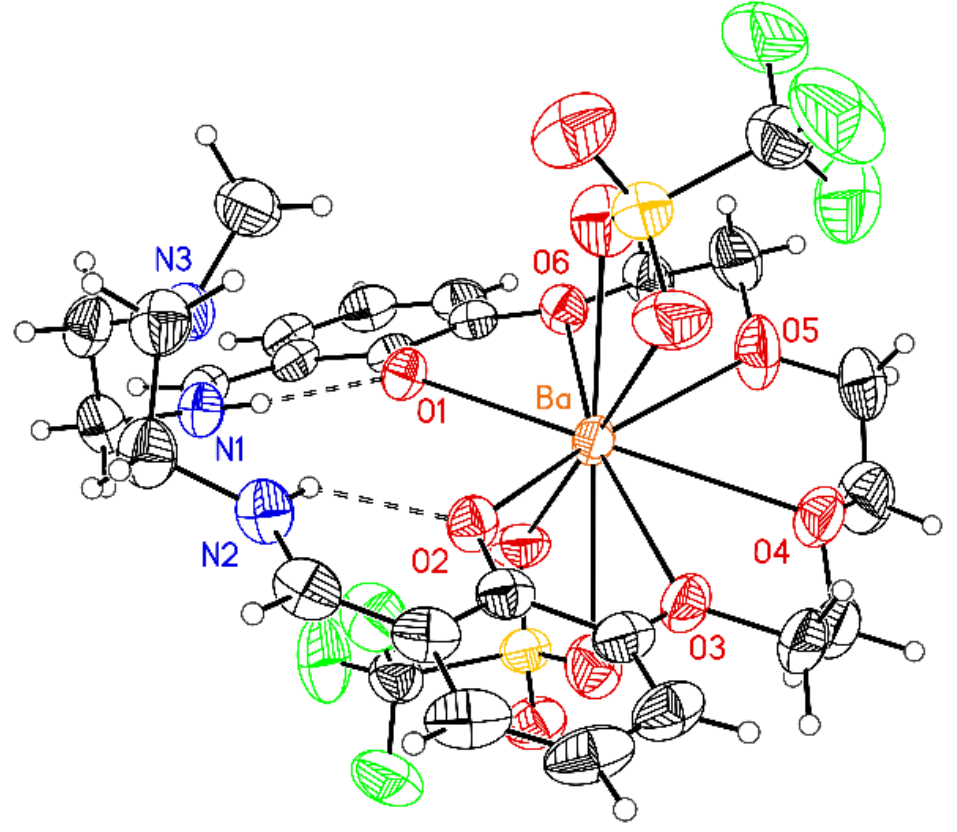

Figure S49. Solid-state structure (from XRD) of $\mathbf{L}^{\text {salben }} \mathbf{H}_{2}$ Ba. Displacement ellipsoids are shown at the $50 \%$ probability level. 


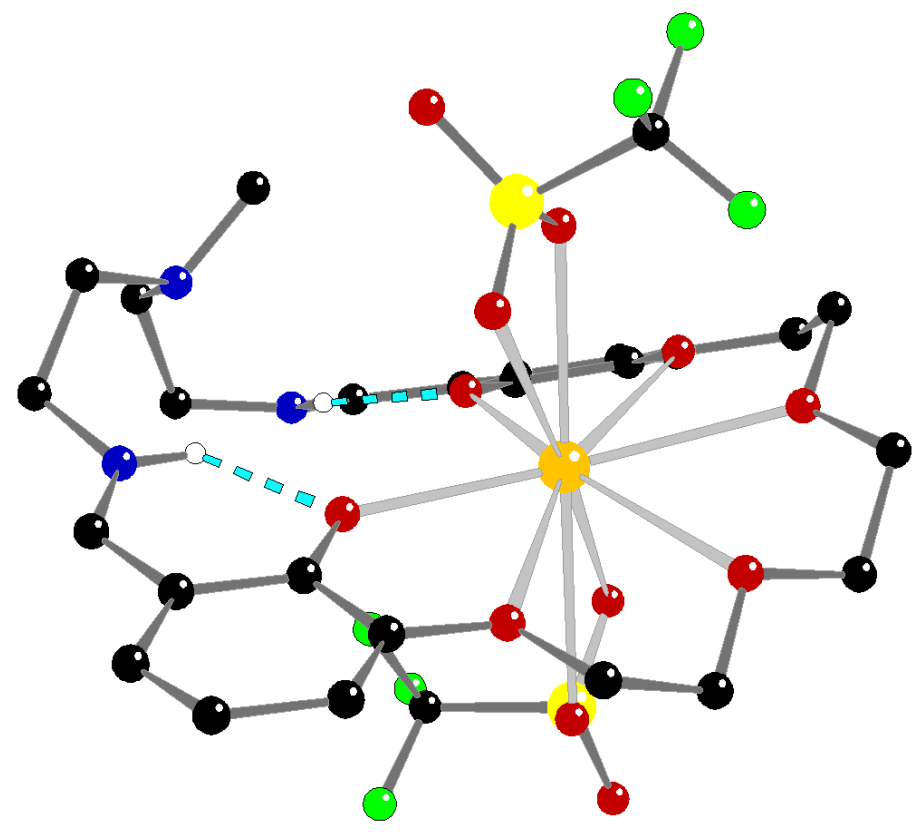

Figure S50. Ball and stick representation of $\mathbf{L}^{\text {salben }} \mathbf{H}_{2}$ Ba showing intramolecular H-bonds. 


\section{Special Refinement Details for $\mathbf{L}^{\text {salben}} \mathbf{U O}_{2}$.}

The atoms bonded to amine nitrogen N3 are 80/20 disordered with two alternate orientations about the U-N3 bond. Atoms for the major (80\%) occupancy orientation are labeled with an $\mathrm{A}$ and those for the minor (20\%) occupancy orientation are labeled without an $\mathrm{A}$ in the CIFformat file. Both orientations for this disordered methylamine moiety were restrained to have nearly idealized geometries by using a free variable for the C21-C22, C23-C24, $\mathrm{C} 21 \mathrm{~A}-\mathrm{C} 22 \mathrm{~A}$ and $\mathrm{C} 23 \mathrm{~A}-\mathrm{C} 24 \mathrm{~A}$ bond lengths. This free variable refined to a final value of $1.518(7) \AA$. The remaining bond lengths and angles for this disordered group were restrained to be multiples of this free variable that were consistent with $s p^{3}$-hybridization.

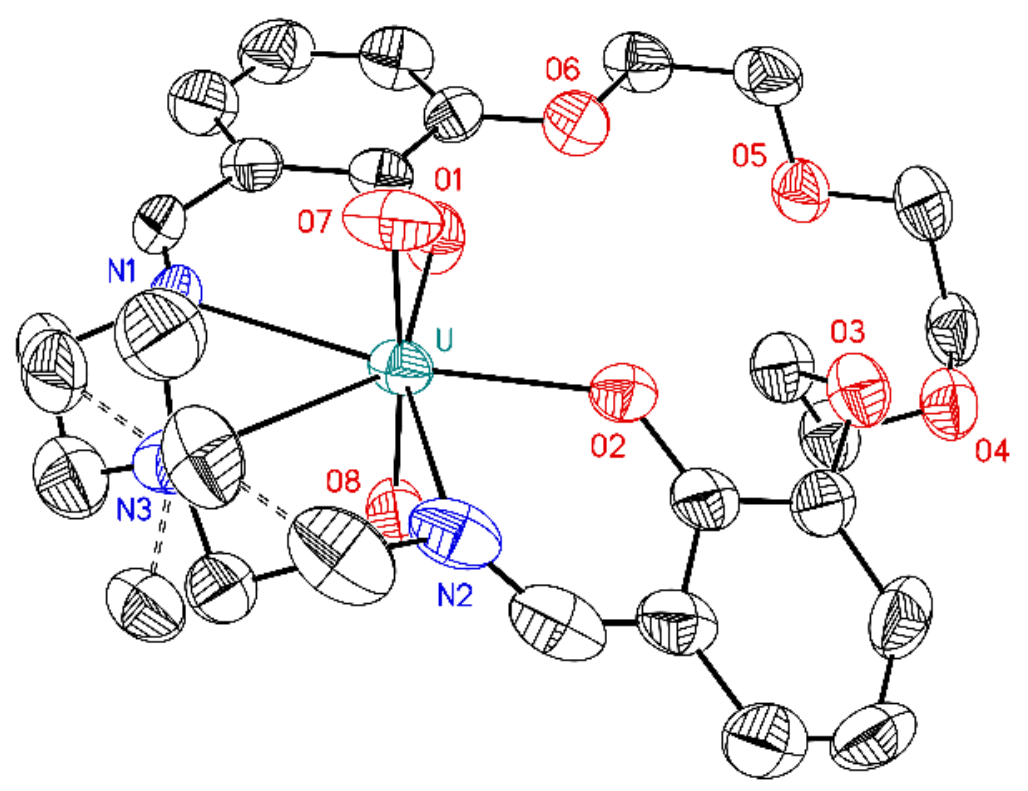

Figure S51. Solid-state structure (from XRD) of $\mathbf{L}^{\text {salben }} \mathbf{U} \mathbf{O}_{2}$. H-atoms are omitted for clarity. Displacement ellipsoids are shown at the 50\% probability level.
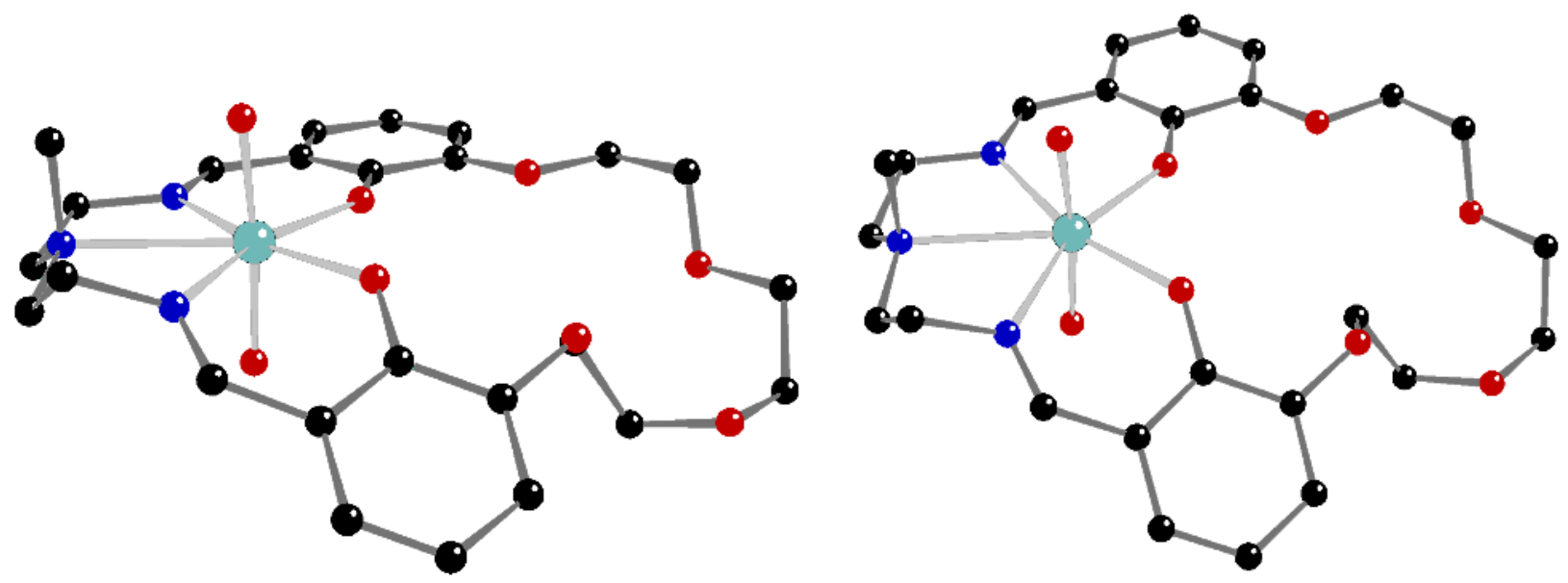

Figure S52. Ball and stick representations of $\mathbf{L}^{\text {salben }} \mathbf{U} \mathbf{O}_{2}$. 


\section{Special Refinement Details for $\mathrm{L}^{\text {salben }} \mathrm{UO}_{2} \mathrm{~K}$.}

The triflate counteranion is bound in a $\kappa^{1}$ fashion to the formally 7 -coordinate $\mathrm{K}^{+}$and is $72 / 28$ disordered with two orientations about the $\mathrm{K}-\mathrm{O} 11$ bond. Both orientations for this disordered triflate moiety were restrained to have nearly idealized geometries by using a free variable for the $\mathrm{S}=\mathrm{O}$ bond length. This free variable refined to a final value of $1.410(6) \AA$. The remaining bond lengths and angles for this disordered group were restrained to be appropriate multiples of this free variable that were consistent with accepted bond lengths and $s p^{3}$-hybridization. The C8-C9 link between O5 and O6 is also 71/29 disordered and these linkages were restrained to be consistent with $s p^{3}$-hybridization. Mild restraints were applied to the anisotropic thermal parameters of partial-occupancy atoms C26, O12', O13', F12', F13' and C26'.

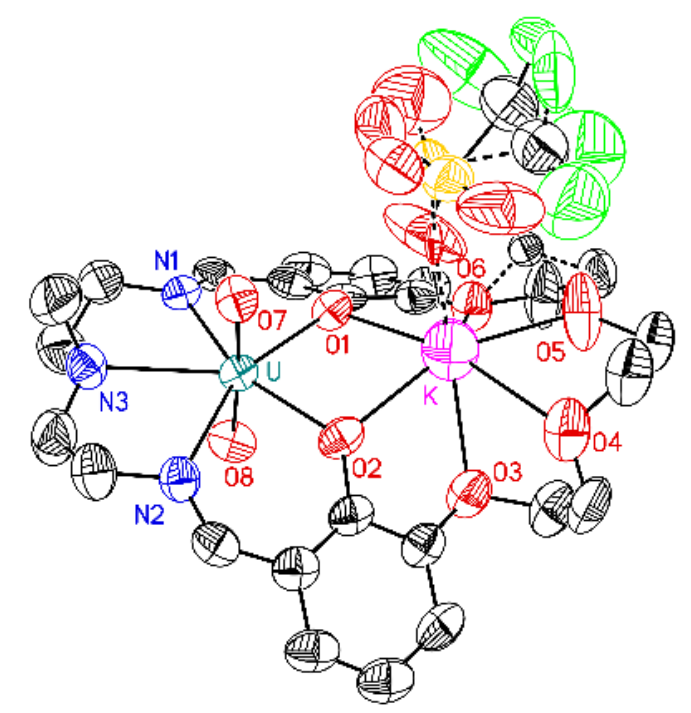

Figure S53. Solid-state structure (from XRD) of $\mathbf{L}^{\text {salben }} \mathbf{U} \mathbf{O}_{2} \mathbf{K}$. H-atoms are omitted for clarity. Displacement ellipsoids are shown at the $50 \%$ probability level.

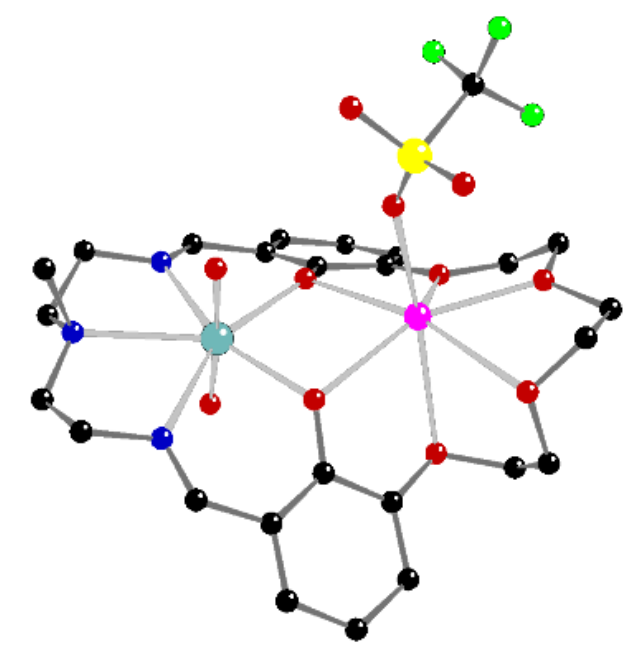

Figure S54. Ball and Stick representation of $\mathbf{L}^{\text {salben }} \mathbf{U O}_{2} \mathbf{K}$. 


\section{Special Refinement Details for $\mathrm{L}^{\text {salben }} \mathrm{UO}_{2} \mathrm{Na}$.}

The triflate counteranion is bound in a $\kappa^{1}$ fashion to the formally 7-coordinate $\mathrm{Na}^{+}$and is $67 / 33$ disordered with two orientations about the $\mathrm{Na}-\mathrm{O} 11$ bond. Both orientations for this disordered triflate moiety were restrained to have nearly idealized geometries by using a free variable for the $\mathrm{S}=\mathrm{O}$ bond length. This free variable refined to a final value of $1.412(5) \AA$. The remaining bond lengths and angles for this disordered group were restrained to be appropriate multiples of this free variable that were consistent with accepted bond lengths and $s p^{3}$-hybridization. The C8-C9 link between O5 and O6 is also 57/43 disordered and these linkages were restrained to be consistent with $s p^{3}$-hybridization. Mild restraints were applied to the anisotropic thermal parameters of partial-occupancy atoms C26, O12', O13', F12', F13' and C26'.

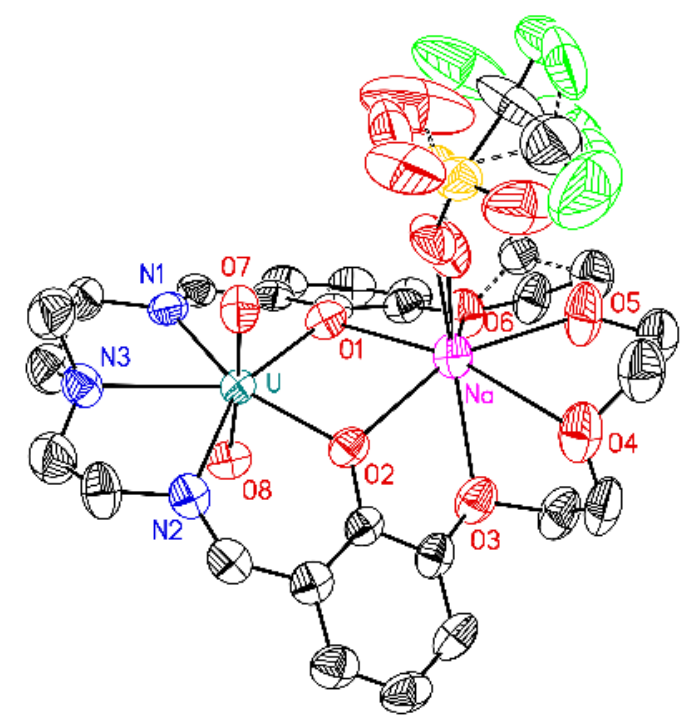

Figure S55. Solid-state structure (from XRD) of $\mathbf{L}^{\text {salben }} \mathbf{U O}_{2} \mathbf{N a}$. H-atoms are omitted for clarity. Displacement ellipsoids are shown at the 50\% probability level.

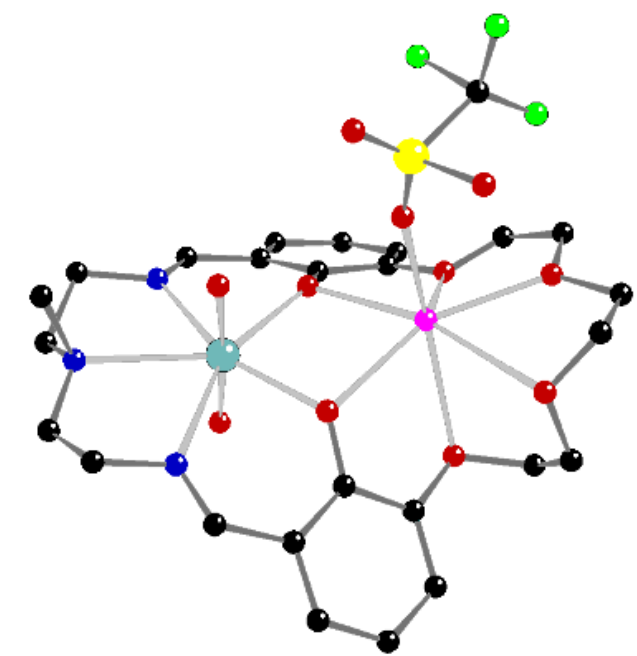

Figure S56. Ball and stick representation of $\mathbf{L}^{\text {salben }} \mathbf{U O}_{2} \mathbf{N a}$. 


\section{Special Refinement Details for $\mathrm{L}^{\text {salben }} \mathrm{UO}_{2} \mathrm{Ca}$.}

Interestingly, no crystals of $\mathbf{L}^{\text {salben}} \mathbf{U} \mathbf{O}_{2} \mathbf{C a}$ suitable for XRD analysis could be grown by vapor diffusion of diethyl ether into acetonitrile. Thus, acetonitrile was replaced by methanol in the successful solvent system for growing single crystals. The vapor diffusion setup was kept at $5^{\circ} \mathrm{C}$ under ambient laboratory atmosphere, giving single crystals after several days. We conclude that both slow exchange of one of the triflate counter anions with methanol at $\mathrm{Ca}^{2+}$ as well as inclusion of a water molecule (described below) resulted in formation of single crystals suitable for XRD that contain a 50/50 mixture of co-crystallized $\mathbf{L}^{\text {salben }} \mathrm{UO}_{2} \mathrm{Ca}(\mathrm{MeOH})_{2}$ and $\mathbf{L}^{\text {salben }} \mathrm{UO}_{2} \mathrm{Ca}(\mathrm{MeOH})\left(\mathrm{H}_{2} \mathrm{O}\right)$ where the second coordinated methanol and coordinated water molecule occupy a disordered site in the asymmetric unit that contains a single $\mathrm{U}$ and a single $\mathrm{Ca}$.

Two methanol molecules or one methanol molecule and a water molecule plus one of the triflate counteranions are each bound in a $\kappa^{1}$ fashion to the formally 9 -coordinate $\mathrm{Ca}^{2+}$ in these two co-crystallized species. A third methanol is present as a solvent molecule of crystallization. The atoms bonded to amine nitrogen $\mathrm{N} 3$ are $65 / 35$ disordered with two alternate orientations about the $\mathrm{U}-\mathrm{N} 3$ bond. Atoms for the minor (35\%) occupancy orientation are labeled with an $\mathrm{A}$ and those for the major (65\%) occupancy orientation are labeled without an $\mathrm{A}$ in the CIF-format file. Both orientations for this disordered methylamine moiety were restrained to have nearly idealized geometries by using a free variable for the $\mathrm{C} 21-\mathrm{C} 22, \mathrm{C} 23-\mathrm{C} 24, \mathrm{C} 21 \mathrm{~A}-\mathrm{C} 22 \mathrm{~A}$ and $\mathrm{C} 23 \mathrm{~A}-\mathrm{C} 24 \mathrm{~A}$ bond lengths. This free variable refined to a final value of 1.525(5) $\AA$. The remaining bond lengths and angles for this disordered group were restrained to be appropriate multiples of this free variable that were consistent with $s p^{3}$-hybridization.

The first coordinated methanol in $\mathbf{L}^{\text {salben }} \mathrm{UO}_{2} \mathbf{C a}(\mathbf{M e O H})_{2}$ is ordered and always present as methanol. But the second coordinated methanol is disordered in the average co-crystallized structure that relates the distinct $\mathrm{L}^{\text {salben }} \mathrm{UO}_{2} \mathrm{Ca}(\mathrm{MeOH})_{2}$ and $\mathrm{L}^{\text {salben }} \mathrm{UO}_{2} \mathrm{Ca}(\mathrm{MeOH})\left(\mathrm{H}_{2} \mathrm{O}\right)$ moieties by a rigorous crystallographic inversion center. The coordination site for the second methanol in the co-crystallized structure is present $50 \%$ of the time as methanol and $50 \%$ of the time as water. They share a common oxygen $(\mathrm{O} 2 \mathrm{~S})$ and H-bonded hydrogen atom (H2SA). This disorder is obviously necessary to form the crystal, and it prevents a short $2.250 \AA$ intermolecular methyl $\bullet \bullet$ methyl contact between pairs of these ligands in contiguous inversion-related molecules if no water were present. The oxygen atom $(\mathrm{O} 2 \mathrm{~S})$ is present $100 \%$ of the time but the carbon atom $(\mathrm{C} 2 \mathrm{~S})$ and its hydrogens are present only $50 \%$ of the time. The other $50 \%$ of the time this methyl group is replaced by the second idealized hydrogen atom (H2SB) of a water molecule. This was confirmed by electron density in a difference Fourier calculated with $\mathrm{C} 2 \mathrm{~S}$ and $\mathrm{O} 2 \mathrm{~S}$ removed from the structural model as well as by refinement of the occupancy factor for $\mathrm{C} 2 \mathrm{~S}$ that refined to $0.65(1)$. The common $\mathrm{O}-\mathrm{H}$ hydrogen atom (H2SA) was located from a difference Fourier and included as an independent isotropic atom in the least-squares refinement cycles. The presence of H2SA for both ligands permits an uninterrupted intermolecular $\mathrm{O}-\mathrm{H} \bullet \bullet \mathrm{O}$ hydrogen-bonding network that stabilizes the crystal and promotes crystallization. The $\mathrm{C}-\mathrm{O}-\mathrm{H}$ groups for the 
other two methanol moieties were incorporated into the structural model as idealized tetrahedral rigid groups that were free to rotate about their $\mathrm{C}-\mathrm{O}$ bonds in least-squares refinement cycles.

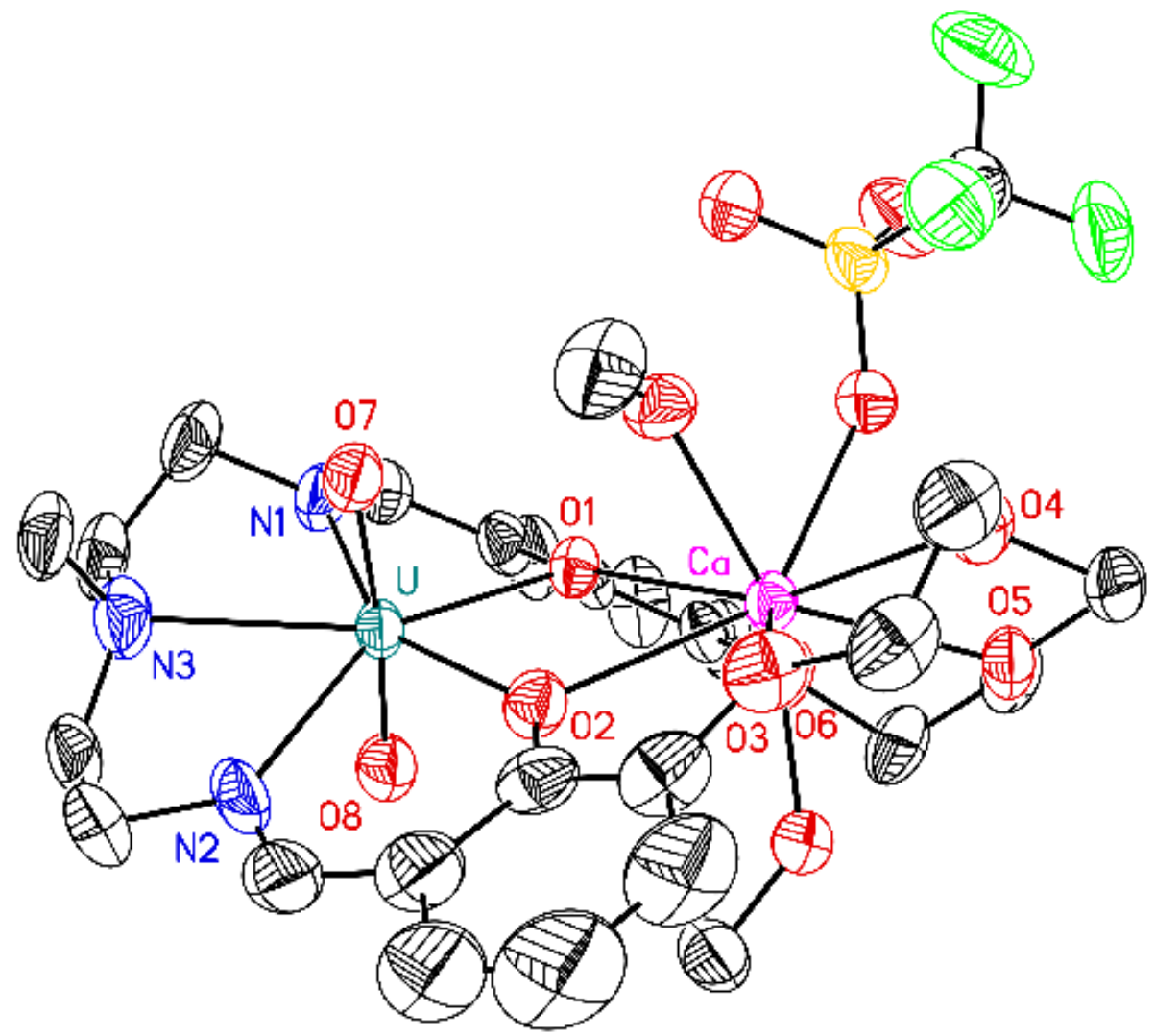

Figure S57. Solid-state structure (from XRD) of $\mathbf{L}^{\text {salben }} \mathbf{U O}_{2} \mathbf{C a}$ showing two methanol molecules coordinated to $\mathrm{Ca}$. $\mathrm{H}$-atoms, disorder in the amine linkage, outer-sphere triflate counteranion, and outer-sphere methanol/water (O2S) are omitted for clarity. Displacement ellipsoids are shown at the $50 \%$ probability level. 


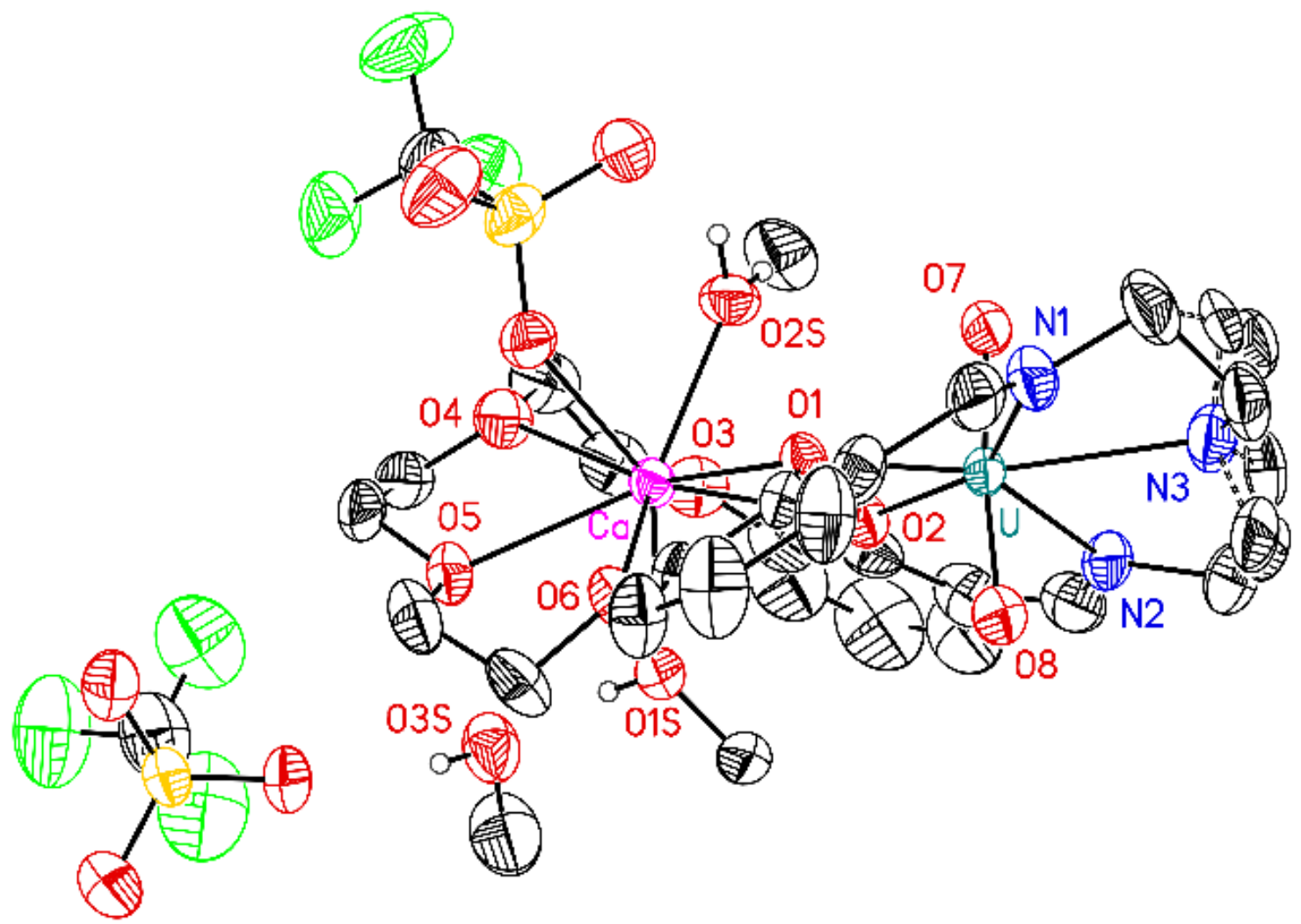

Figure S58. Solid-state structure (from XRD) of $\mathbf{L}^{\text {salben }} \mathbf{U} \mathbf{O}_{2} \mathbf{C a}$ showing half-occupancy methanol (O2S and methyl carbon) coordinated to $\mathrm{Ca}$ and showing the unique hydrogen from the half-occupancy coordinated water (H2SB). All H-atoms except those associated with the methanol (and water) solvent molecules are omitted for clarity. Displacement ellipsoids are shown at the $50 \%$ probability level. 


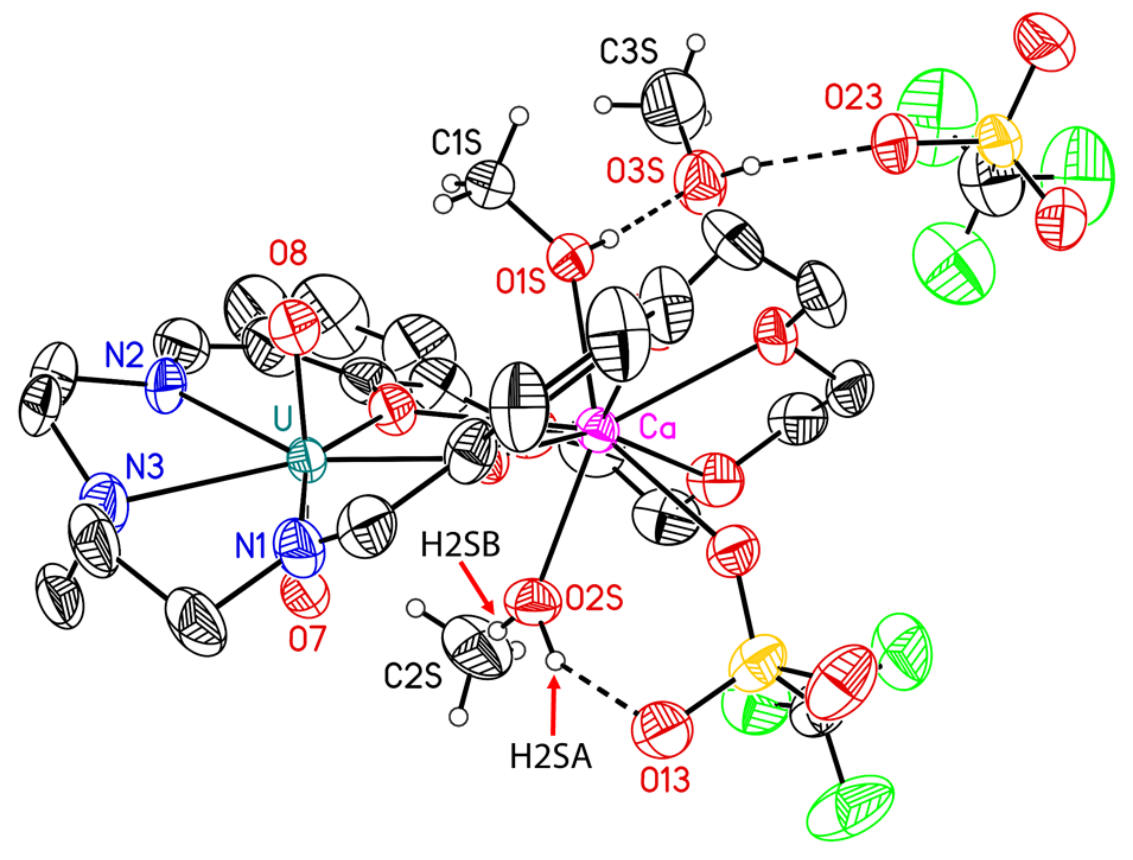

Figure S59. Solid-state structure (from XRD) of $\mathbf{L}^{\text {salben }} \mathbf{U O}_{2} \mathbf{C a}$ showing hydrogen bonds involving the methanol and methanol/water solvent molecules. All H-atoms except those associated with the methanol solvent molecules are omitted for clarity. Displacement ellipsoids are shown at the 50\% probability level. Note that the methyl group associated with $\mathrm{C} 2 \mathrm{~S}$ is present $50 \%$ of the time, and the hydrogen (H2SB; associated with a corresponding bound water) near $\mathrm{C} 2 \mathrm{~S}$ is present $50 \%$ of the time. $\mathrm{O} 2 \mathrm{~S}$ is common between the bound methanol and water. H2SA was located in a difference Fourier and included as an independent isotropic atom in the least-squares refinement.

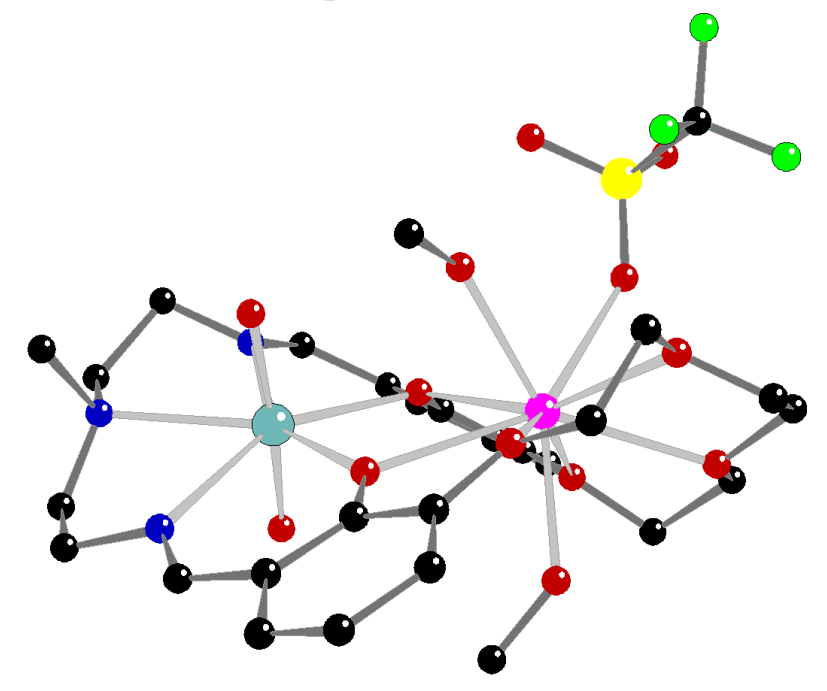

Figure S60. Ball and stick representation of $\mathbf{L}^{\text {salben }} \mathbf{U O}_{2} \mathbf{C a}$. 


\section{Special Refinement Details for $\mathrm{L}^{\text {salben }} \mathrm{UO}_{2} \mathrm{Y}$.}

No special refinement was required. An acetonitrile molecule and two of the triflate counteranions are each bound in a $\kappa^{1}$ fashion to the formally 9-coordinate $\mathrm{Y}^{3+}$.

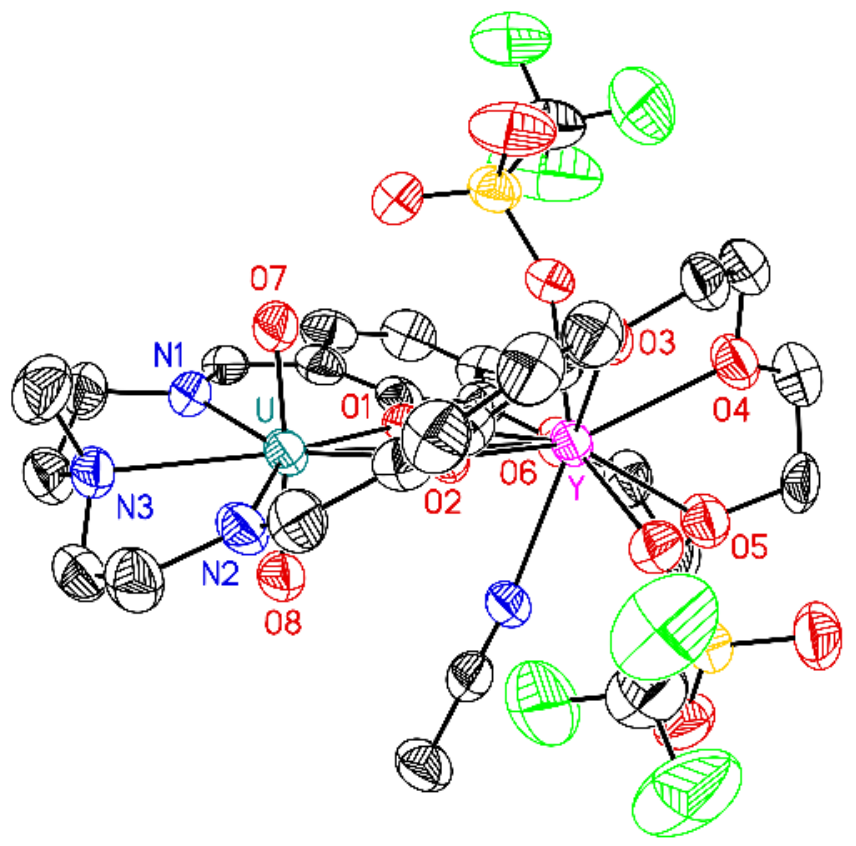

Figure S61. Solid-state structure (from XRD) of $\mathbf{L}^{\text {salben }} \mathbf{U O}_{2} \mathbf{Y}$. H-atoms and outer-sphere triflate counteranion are omitted for clarity. Displacement ellipsoids are shown at the 50\% probability level.

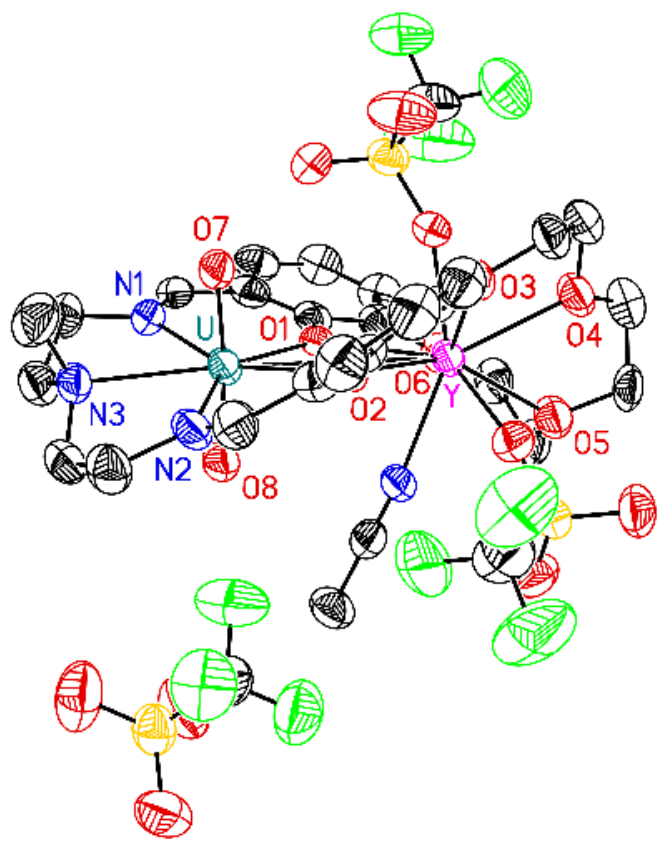

Figure S62. Solid-state structure (from XRD) of $\mathbf{L}^{\text {salben }} \mathbf{U} \mathbf{O}_{2} \mathbf{Y}$. H-atoms are omitted for clarity. Displacement ellipsoids are shown at the $50 \%$ probability level. 


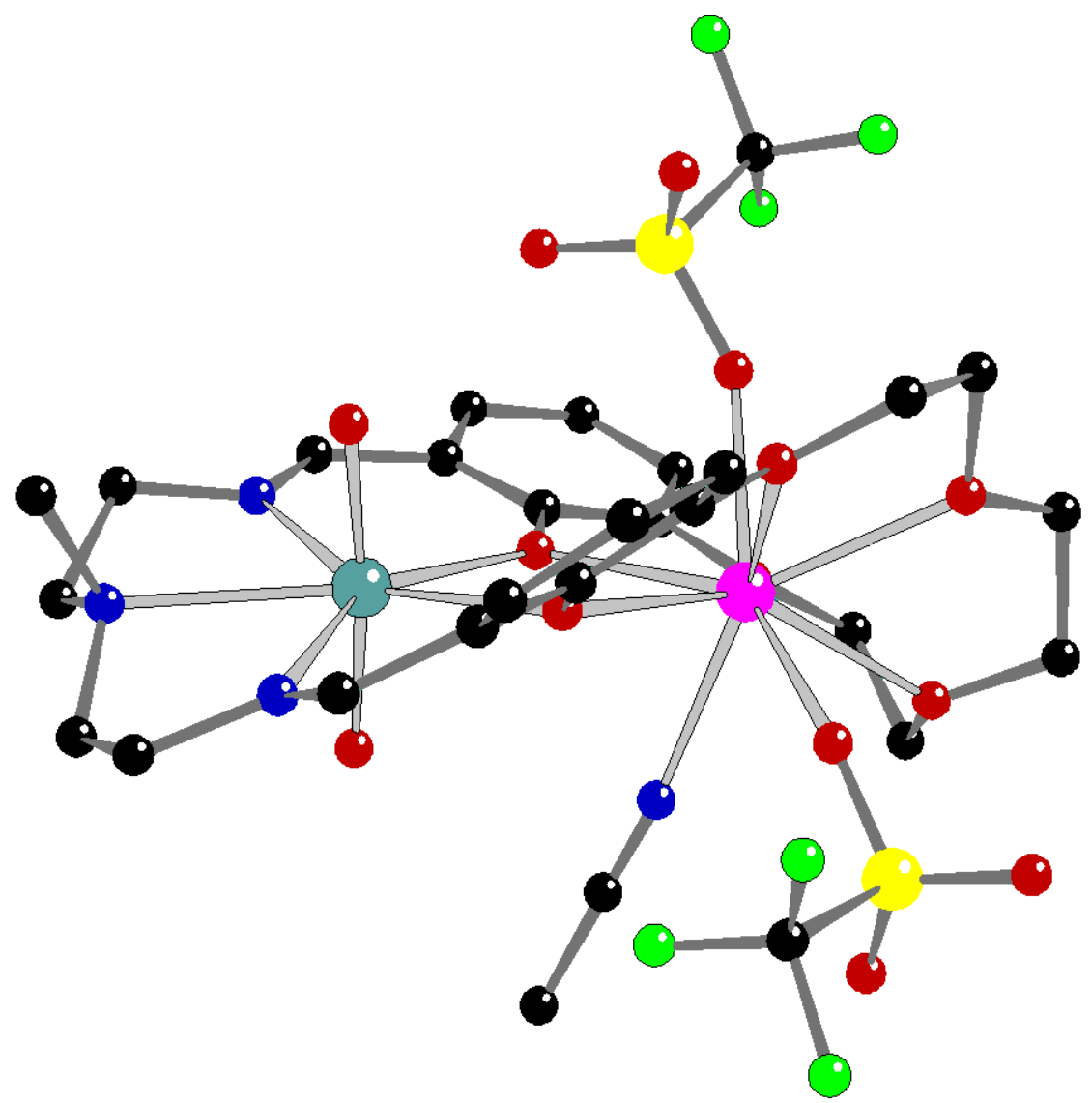

Figure S63. Ball and stick representation of $\mathbf{L}^{\text {salben }} \mathbf{U} \mathbf{O}_{2} \mathbf{Y}$. 
Table S1. Crystal and Refinement Data for $\mathbf{L}^{\text {salben}} \mathbf{H}_{2} \mathbf{B a}$ and $\mathbf{L}^{\text {salben}} \mathbf{U O}_{2}$.

\begin{tabular}{|c|c|c|}
\hline & $\mathrm{L}^{\text {salben }} \mathrm{H}_{2} \mathrm{Ba}$ & $\mathbf{L}^{\text {salben }} \mathbf{U O}_{2}$ \\
\hline CCDC number & 1960625 & 1960626 \\
\hline empirical formula & $\mathrm{C}_{27} \mathrm{H}_{33} \mathrm{BaF}_{6} \mathrm{~N}_{3} \mathrm{O}_{12} \mathrm{~S}_{2}$ & $\mathrm{C}_{25} \mathrm{H}_{31} \mathrm{~N}_{3} \mathrm{O}_{8} \mathrm{U}$ \\
\hline formula weight & 907.02 & 739.56 \\
\hline $\mathbf{T}(\mathbf{K})$ & 200 & 200 \\
\hline wavelength, $\AA$ & 1.54178 & 1.54178 \\
\hline crystal system & orthorhombic & orthorhombic \\
\hline space group & $\operatorname{Pbca}\left(\mathrm{D}_{2 \mathrm{~h}}{ }^{15}-\right.$ No. 61$)$ & $\mathrm{P} 2{ }_{1} 2{ }_{1}{ }_{1}\left(\mathrm{D}_{2}{ }^{4}-\right.$ No. 19$)$ \\
\hline$a, \AA$ & $10.9261(6)$ & $11.8509(3)$ \\
\hline$b, \AA$ & $17.1581(9)$ & $12.0635(4)$ \\
\hline$c, \AA$ & $37.691(2)$ & $17.8749(5)$ \\
\hline$a, \operatorname{deg}$ & 90 & 90 \\
\hline$\beta, \operatorname{deg}$ & 90 & 90 \\
\hline$\gamma, \operatorname{deg}$ & 90 & 90 \\
\hline Volume, $\AA^{3}$ & $7065.9(7)$ & $2555.5(1)$ \\
\hline $\mathbf{Z}$ & 8 & 4 \\
\hline$\rho_{\text {calcd }}, g / \mathbf{c m}^{3}$ & 1.705 & 1.922 \\
\hline$F(000)$ & 3632.0 & 1432.0 \\
\hline crystal dimensions, $\mathbf{m m}^{3}$ & $0.135 \times 0.13 \times 0.03$ & $0.135 \times 0.095 \times 0.065$ \\
\hline $2 \theta$ range, deg & 9.36 to 137.01 & 8.84 to 136.71 \\
\hline index ranges & $\begin{array}{c}-13 \leq \mathrm{h} \leq 11,-20 \leq \mathrm{k} \leq 18,-41 \\
\leq 1 \leq 44\end{array}$ & $\begin{array}{c}-14 \leq \mathrm{h} \leq 14,-14 \leq \mathrm{k} \leq 12,-21 \\
\leq 1 \leq 16\end{array}$ \\
\hline reflections collected & 39237 & 21288 \\
\hline independent reflections & $\begin{array}{c}6423\left[\mathrm{R}_{\text {int }}=0.061, \mathrm{R}_{\text {sigma }}=\right. \\
0.104]\end{array}$ & $\begin{array}{c}4586\left[\mathrm{R}_{\text {int }}=0.052, \mathrm{R}_{\text {sigma }}=\right. \\
0.044]\end{array}$ \\
\hline absorption correction & multi-scan & multi-scan \\
\hline Max./Min. Transmission & $0.538 / 1.000$ & $0.570 / 1.000$ \\
\hline Refinement method & Full-matrix least-squares on $\mathrm{F}^{2}$ & Full-matrix least-squares on $\mathrm{F}^{2}$ \\
\hline Data/restraints/parameters & $6423 / 0 / 592$ & $4586 / 38 / 364$ \\
\hline Goodness-of-fitc on $\mathbf{F}^{2}$ & 1.032 & 1.043 \\
\hline $\mathbf{R}_{1},{ }^{\mathrm{a}} \mathbf{w R}_{2}{ }^{\mathrm{b}}[\mathrm{I}>\mathbf{2 \sigma}(\mathrm{I})]$ & $\mathrm{R}_{1}=0.037, \mathrm{wR}_{2}=0.098$ & $\mathrm{R}_{1}=0.030, \mathrm{wR}_{2}=0.070$ \\
\hline $\mathbf{R}_{1},{ }^{a} \mathbf{w R}_{2}{ }^{b}$ (all data) & $\mathrm{R}_{1}=0.041, \mathrm{wR}_{2}=0.101$ & $\mathrm{R}_{1}=0.0322, \mathrm{wR}_{2}=0.071$ \\
\hline Largest diff. peak \& hole & 0.57 and $-0.95 \mathrm{e}^{-} / \AA^{3}$ & 1.56 and $-1.21 \mathrm{e}^{-} / \AA^{3}$ \\
\hline
\end{tabular}


Table S2. Crystal and Refinement Data for $\mathbf{L}^{\text {salben }} \mathbf{U O}_{2} \mathbf{K}$ and $\mathbf{L}^{\text {salben }} \mathbf{U O}_{2} \mathrm{Na}$.

\begin{tabular}{|c|c|c|}
\hline & $\mathbf{L}^{\text {salben }} \mathrm{UO}_{2} \mathbf{K}$ & $\mathrm{L}^{\text {salben }} \mathrm{UO}_{2} \mathrm{Na}$ \\
\hline CCDC number & 1960628 & 1960629 \\
\hline empirical formula & $\mathrm{C}_{26} \mathrm{H}_{31} \mathrm{~F}_{3} \mathrm{KN}_{3} \mathrm{O}_{11} \mathrm{SU}$ & $\mathrm{C}_{26} \mathrm{H}_{31} \mathrm{~F}_{3} \mathrm{NaN}_{3} \mathrm{O}_{11} \mathrm{SU}$ \\
\hline formula weight & 927.73 & 911.62 \\
\hline $\mathbf{T}(\mathbf{K})$ & 200 & 200 \\
\hline wavelength, $\AA$ & 1.54178 & 1.54178 \\
\hline crystal system & orthorhombic & orthorhombic \\
\hline space group & $\mathrm{P} 2{ }_{1} 2_{1} 2_{1}\left(\mathrm{D}_{2}{ }^{4}-\right.$ No. 19$)$ & $\mathrm{P} 2{ }_{1} 2_{1} 2_{1}\left(\mathrm{D}_{2}{ }^{4}-\right.$ No. 19$)$ \\
\hline$a, \AA$ & $12.9299(6)$ & $12.9352(2)$ \\
\hline$b, \AA$ & $13.2222(6)$ & $13.2651(2)$ \\
\hline$c, \AA$ & $18.4887(9)$ & $18.4739(3)$ \\
\hline$a, \operatorname{deg}$ & 90 & 90 \\
\hline$\beta$, deg & 90 & 90 \\
\hline$\gamma, \operatorname{deg}$ & 90 & 90 \\
\hline Volume, $\AA^{3}$ & $3160.9(3)$ & $3169.88(9)$ \\
\hline $\mathbf{Z}$ & 4 & 4 \\
\hline$\rho_{\text {calcd }}, \mathbf{g} / \mathbf{c m}^{3}$ & 1.950 & 1.910 \\
\hline $\mathbf{F}(000)$ & 1800.0 & 1768.0 \\
\hline crystal dimensions, $\mathbf{m m}^{3}$ & $0.17 \times 0.085 \times 0.04$ & $0.13 \times 0.04 \times 0.02$ \\
\hline $2 \theta$ range, deg & 8.22 to 136.85 & 8.21 to 140.49 \\
\hline index ranges & $\begin{array}{c}-10 \leq \mathrm{h} \leq 15,-15 \leq \mathrm{k} \leq 15,-22 \\
\leq 1 \leq 14\end{array}$ & $\begin{array}{c}-13 \leq \mathrm{h} \leq 15,-10 \leq \mathrm{k} \leq 16,-20 \\
\leq 1 \leq 22\end{array}$ \\
\hline reflections collected & 12833 & 12908 \\
\hline independent reflections & $\begin{array}{c}5277\left[\mathrm{R}_{\text {int }}=0.039, \mathrm{R}_{\text {sigma }}=\right. \\
0.046]\end{array}$ & $\begin{array}{c}5437\left[\mathrm{R}_{\text {int }}=0.033, \mathrm{R}_{\text {sigma }}=\right. \\
0.039]\end{array}$ \\
\hline absorption correction & numerical & numerical \\
\hline Max./Min. Transmission & $0.054 / 1.000$ & $0.162 / 1.000$ \\
\hline Refinement method & Full-matrix least-squares on $\mathrm{F}^{2}$ & Full-matrix least-squares on $\mathrm{F}^{2}$ \\
\hline Data/restraints/parameters & $5277 / 74 / 496$ & $5437 / 50 / 496$ \\
\hline Goodness-of-fit ${ }^{\mathfrak{c}}$ on $\mathbf{F}^{2}$ & 1.088 & 1.095 \\
\hline $\mathrm{R}_{1},{ }^{\mathrm{a}}{ } \mathbf{R}_{2}{ }^{\mathrm{b}}[\mathrm{I}>\mathbf{2 \sigma}(\mathrm{I})]$ & $\mathrm{R}_{1}=0.036, \mathrm{wR}_{2}=0.095$ & $\mathrm{R}_{1}=0.027, \mathrm{wR}_{2}=0.064$ \\
\hline $\mathbf{R}_{1},{ }^{a}{ } \mathbf{R}_{2}{ }^{b}$ (all data) & $\mathrm{R}_{1}=0.040, \mathrm{wR}_{2}=0.099$ & $\mathrm{R}_{1}=0.030, \mathrm{wR}_{2}=0.066$ \\
\hline Largest diff. peak \& hole & $1.36 /-1.46 \mathrm{e}^{-} / \AA^{3}$ & $1.11 /-0.58 \mathrm{e}^{-} / \AA^{3}$ \\
\hline
\end{tabular}


Table S3. Crystal and Refinement Data for $\mathbf{L}^{\text {salben }} \mathbf{U} \mathbf{O}_{2} \mathrm{Ca}$ and $\mathbf{L}^{\text {salben }} \mathbf{U} \mathbf{O}_{2} \mathbf{Y}$.

\begin{tabular}{|c|c|c|}
\hline & $\mathrm{L}^{\text {salben }} \mathrm{UO}_{2} \mathrm{Ca}$ & $\mathbf{L}^{\text {salben }} \mathrm{UO}_{2} \mathbf{Y}$ \\
\hline CCDC number & 1960630 & 1960631 \\
\hline empirical formula & $\mathrm{C}_{29.5} \mathrm{H}_{42} \mathrm{CaF}_{6} \mathrm{~N}_{3} \mathrm{O}_{17} \mathrm{~S}_{2} \mathrm{U}$ & $\mathrm{C}_{30} \mathrm{H}_{34} \mathrm{~F}_{9} \mathrm{~N}_{4} \mathrm{O}_{17} \mathrm{~S}_{3} \mathrm{UY}$ \\
\hline formula weight & 1166.89 & 1316.73 \\
\hline $\mathbf{T}(\mathbf{K})$ & 200 & 200 \\
\hline wavelength, $\AA$ & 1.54178 & 1.54178 \\
\hline crystal system & triclinic & Triclinic \\
\hline space group & P-1 ( $\mathrm{C}_{\mathrm{i}}{ }^{1}$-No. 2$)$ & P-1 ( $\mathrm{C}_{\mathrm{i}}^{1}$-No. 2$)$ \\
\hline$a, \AA$ & $12.7589(9)$ & $9.1814(6)$ \\
\hline$b, \AA$ & $13.2831(9)$ & $13.6032(8)$ \\
\hline$c, \AA$ & $13.7644(10)$ & $18.8769(12)$ \\
\hline$a$, deg & $79.402(3)$ & $102.095(5)$ \\
\hline$\beta, \operatorname{deg}$ & $64.575(3)$ & $102.738(6)$ \\
\hline$\gamma, \operatorname{deg}$ & $81.805(3)$ & $103.991(5)$ \\
\hline Volume, $\AA^{3}$ & $2065.6(3)$ & $2143.6(2)$ \\
\hline $\mathbf{Z}$ & 2 & 2 \\
\hline$\rho_{\text {calcd, }}, \mathbf{g} / \mathbf{c m}^{3}$ & 1.876 & 2.040 \\
\hline$F(000)$ & 1148.0 & 1276.0 \\
\hline crystal dimensions, $\mathbf{m m}^{3}$ & $0.13 \times 0.085 \times 0.06$ & $0.03 \times 0.03 \times 0.025$ \\
\hline $2 \theta$ range, deg & 6.79 to 136.91 & 5.00 to 140.87 \\
\hline index ranges & $\begin{array}{c}-15 \leq \mathrm{h} \leq 13,-15 \leq \mathrm{k} \leq 15,-16 \\
\leq 1 \leq 16\end{array}$ & $\begin{array}{c}-11 \leq \mathrm{h} \leq 9,-16 \leq \mathrm{k} \leq 16,-21 \\
\leq 1 \leq 23\end{array}$ \\
\hline reflections collected & 32430 & 28130 \\
\hline independent reflections & $\begin{array}{c}7473[\text { Rint }=0.059, \text { Rsigma }= \\
0.052]\end{array}$ & $\begin{array}{c}7605[\text { Rint }=0.077, \text { Rsigma }= \\
0.068]\end{array}$ \\
\hline absorption correction & multi-scan & multi-scan \\
\hline Max./Min. Transmission & $0.614 / 1.000$ & $0.704 / 1.000$ \\
\hline Refinement method & Full-matrix least-squares on $\mathrm{F}^{2}$ & Full-matrix least-squares on $\mathrm{F}^{2}$ \\
\hline Data/restraints/parameters & $7473 / 19 / 581$ & $7605 / 0 / 587$ \\
\hline Goodness-of-fit ${ }^{c}$ on $F^{2}$ & 1.093 & 1.067 \\
\hline $\mathrm{R}_{1},{ }^{\mathrm{a}} \mathrm{wR}_{2}{ }^{\mathrm{b}}[\mathrm{I}>\mathbf{2 \sigma}(\mathrm{I})]$ & $\mathrm{R}_{1}=0.037, \mathrm{wR}_{2}=0.085$ & $\mathrm{R}_{1}=0.050, \mathrm{wR}_{2}=0.122$ \\
\hline $\mathbf{R}_{1},{ }^{\mathrm{a}} \mathbf{w R}_{2}{ }^{\mathrm{b}}$ (all data) & $\mathrm{R}_{1}=0.040, \mathrm{wR}_{2}=0.087$ & $\mathrm{R}_{1}=0.067, \mathrm{wR}_{2}=0.133$ \\
\hline Largest diff. peak \& hole & $1.52 /-1.16 \mathrm{e}^{-} / \AA^{3}$ & $2.34 /-1.18 \mathrm{e}^{-} / \AA^{3}$ \\
\hline
\end{tabular}




\section{References}

(1) Perrin, D. D. Ionisation Constants of Inorganic Acids and Bases in Aqueous Solution (Pergamon, 1982).

(2) Nicholson, R. S.; Shain, I. Anal. Chem. 1964, 36, 706-723.

(3) Jakubowska, M. Electroanalysis 2011, 23, 553-572.

(4) Savéant, J.-M. Elements of Molecular and Biomolecular Electrochemistry. Wiley: Hoboken, NJ, 2006.

(5) Randles, J. E. B. Trans. Faraday Soc. 1948, 44, 327-338.

(6) Ševčik, A. Collect. Czech. Chem. Commun. 1948, 13, 349-377

(7) SAINT. Ver. 8.34A. Bruker Analytical X-ray Systems: Madison, WI, June 2014.

(8) Sheldrick, G. M., SADABS (version 2008/1): Program for Absorption Correction for Data from Area Detector Frames, University of Göttingen, 2008.

(9) Sheldrick, G., Acta Crystallogr., Sect. A: Found. Crystallogr. 2015, 71, 3-8.

(10) Sheldrick, G. Acta Crystallogr., Sect. C: Cryst. Struct. Commun. 2015, 71, 3-8.

(11) Dolomanov, O. V.; Bourhis, L. J.; Gildea, R. J.; Howard, J. A. K.; Puschmann, H. J. Appl. Crystallogr. 2009, 42, 339-341. 